
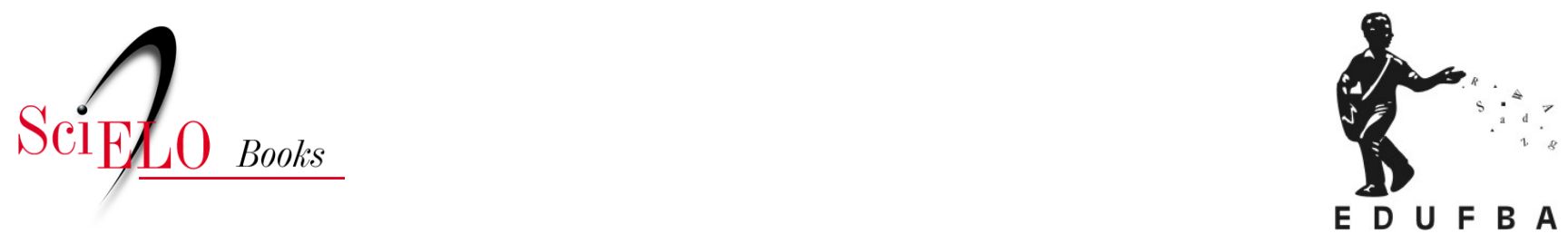

\title{
Saúde para todos, já!
}

\author{
Lana Bleicher \\ Taís Bleicher
}

BLEICHER, L., and BLEICHER, T. Saúde para todos, já! [online]. 3rd ed. Salvador: EDUFBA, 2016, 137 p. ISBN 978-85-232-2005-1. https://doi.org/10.7476/9788523220051.

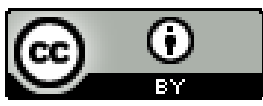

All the contents of this work, except where otherwise noted, is licensed under a Creative Commons Attribution 4.0 International license.

Todo o conteúdo deste trabalho, exceto quando houver ressalva, é publicado sob a licença Creative Commons Atribição 4.0. 
SAÚDE

PARA TODOS, JÁ! 
UNIVERSIDADE FEDERAL DA BAHIA

Reitor

João Carlos Salles Pires da Silva

Vice-reitor

Paulo Miguez

Assessor do Reitor

Paulo Costa Lima

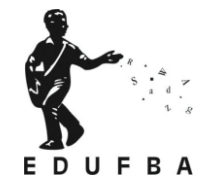

EDITORA DA UNIVERSIDADE

FEDERAL DA BAHIA

Diretora

Flávia Goulart Mota Garcia Rosa

Conselho Editorial

Alberto Brum Novaes

Angelo Szaniecki Perret Serpa

Caiuby Álves da Costa

Charbel Niño El Hani

Cleise Furtado Mendes

Dante Eustachio Lucchesi Ramacciotti

Evelina de Carvalho Sá Hoisel

José Teixeira Cavalcante Filho

Maria Vidal de Negreiros Camargo 
SAUDDE

za edição

EDUFBA
Salvador
2016 
2015, Lana Bleicher e Taís Bleicher

Direitos dessa edição cedidos à Edufba.

Feito o Depósito Legal

1a edição: 2003, Étera.

2a edição: 2004, Expressão Gráfica.

Grafia atualizada conforme o Acordo Ortográfico da Língua Portuguesa de 1990, em vigor no Brasil desde 2009.

\section{PROJETO GRÁFICO}

Gabriel Cayres

ILUSTRAÇÃO DA CAPA

César Miranda

REVISÃO E NORMALIZAÇÃO

Alassol Queiroz e Ricardo Boxus

\section{SISTEMA DE BIBLIOTECAS - UFBA}

\section{Bleicher, Lana.}

Saúde para todos, já! / Lana Bleicher, Taís Bleicher. - 3. ed. - Salvador: EDUFBA, 2016. $137 \mathrm{p}$.

\section{ISBN 978-85-232-1513-2}

Sistema Único de Saúde (Brasil). 2. Odontologia preventiva. 3. Odontologia sanitária. 4. Saúde pública - Administração. 5. Medicina preventiva. 6. Vigilância sanitária. I. Bleicher, Taís.

$$
\text { CDD - 362.10981 }
$$

Editora filiada à

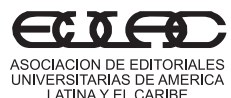
SOCIACION DE EDITORIALES
UNIVERSITARIAS DE AMERICA
LATINA Y EL CARIBE

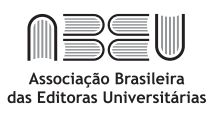

$\mathrm{CBaL}$

Câmara Bahiana do Livro

\section{EDITORA DA UFBA}

Rua Barão de Jeremoabo $\mathrm{s} / \mathrm{n}$ - Campus de Ondina 40170-115 - Salvador - Bahia

Tel.: +55 71 3283-6164

Fax: +55 71 3283-6160

www.edufba.ufba.br

edufba@ufba.br 


\section{SUMÁRIO}

7 INTRODUÇÃO

9 PARTE 1: Introdução ao Sistema Único de Saúde (SUS)

11 Uma provocação

15 Esse tal de SUS

41 Participando do SUS

$55 \quad$ Organizando o SUS

69 Promovendo a saúde

83 PARTE 2: Os modelos de atenção à saúde bucal e à saúde mental

89 Modelos de atenção à saúde bucal

103 Loucura

111 Loucura e doença mental

127 CONCLUSÕES

131 REFERÊNCIAS 


\section{INTRODUÇÃO}

A aula, toda ela, deve ser um ato de amor, uma dança, um orgasmo múltiplo, um ato político, uma manifestação de indignação contra as injustiças. Aqueles que não vêem isso em uma aula, aqueles que jamais se arrepiaram com a descoberta de um dos seus alunos, aqueles que jamais souberam o que é velar

à noite as palavras do dia seguinte, jamais saberão, jamais sentirão o prazer que a profissão de professor pode proporcionar.

Manoel Fernandes (2003)

O Sistema Único de Saúde (SUS) foi uma conquista histórica que se aproxima de três décadas de existência. O estabelecimento do direito à saúde pela Constituição Federal de 1988 marca o início de um grande caminho de transformação: das estruturas sanitárias até então existentes; das suas formas de financiamento; mas, fundamentalmente, a transformação das pessoas. Gestores, trabalhadores e usuários precisavam conhecer o SUS, compreendê-lo e torná-lo uma realidade. Muito havia a ser construído e inventado. 
Hoje, muito já se fez. Cursos de graduação foram vinculados aos serviços de saúde. A formação universitária foi transformada de forma a abranger a Saúde Coletiva. Escolas de Saúde Pública proliferam no Brasil, realizando a formação permanente dos profissionais já em serviço. A rede se ampliou e se complexificou. Conferências municipais, estaduais e nacionais de saúde acontecem com alguma frequência. Novas indagações são feitas e novas pessoas se dedicam, a cada dia, a construir o SUS.

Este livro foi feito com o propósito de apresentá-lo. Como surgiu, quais são seus princípios, campos de atuação, como se distribuem as suas competências, que formas de participação prevê, como se organiza, de forma geral. Mais especificamente, são apresentados os modelos de saúde bucal e a forma de atenção à saúde mental no Brasil. Tudo isto partindo de ilustrações, numa tentativa de aproximar a leveza da escrita a situações possíveis nos diversos Brasis. 
PARTE I

de Saúde (SUS) 


\section{UMA PROVOCAÇÃO}

Responda rápido: quanto vale sua saúde? Por quanto você a venderia? Se essas perguntas Ihe causaram estranheza, talvez seja porque você ainda não tenha se dado conta de que, na sociedade contemporânea, a saúde pode ser tratada como uma mercadoria. Se alguém não pode pagá-la, o que se há de fazer? Que trate de encontrar almas caridosas que se compadeçam de sua situação.

Acontece que, quando aplicado à saúde, há furos nesse raciocínio mercadológico. Por exemplo: se eu quiser comprar um sapato, visito várias lojas até decidir qual comprar. Comparo preços, modelos, qualidades. Se nenhum me agradar, volto para casa e, outro dia, procuro novamente. Com a saúde, não: ninguém escolhe estar saudável, todos precisam estar saudáveis. A ninguém é dada a possibilidade de optar pela doença que deseja adoecer. Imagine o médico dando o diagnóstico ao paciente e este dizendo: "Ah não, doutor, insuficiência renal é uma doença muito cara, prefiro uma dor de barriga. Vamos negociar de novo, senão eu vou a outro médico". Não dá para imaginar, não é?

Essa não é a única visão sobre o assunto. Há também os que consideram que saúde não pode ser tratada como mercadoria, pois a saúde é um bem; e não somente para quem a tem, mas para toda a coletividade. 
O sapato comprado na loja vai beneficiar apenas a quem o adquiriu, enquanto que pessoas saudáveis são um recurso valioso de toda uma sociedade. Crianças doentes aprendem menos na escola. Trabalhadores doentes produzem menos. Idosos doentes requerem de toda a família cuidados maiores. Pessoas com doenças transmissíveis podem colocar em risco um grupo inteiro.

Portanto, podemos confrontar pelo menos duas visões diferentes: a de que saúde pode e deve ser comprada e a de que saúde pode e deve ser garantida às pessoas.

Dito isso, perguntamos: qual é a visão de saúde que predomina em nossa sociedade? 


\section{HISTÓRIA - PARA FAZER PENSAR}

\section{ERA UMA VEZ}

Foi na encosta da Serra da Purpurina que nasceu a cidade de Musa Paradisíaca. No início, a economia da cidade era completamente centrada no cultivo de bananas, que eram exportadas in natura para o estrangeiro. O porto de São João, a linha de trem, tudo foi construído para facilitar o comércio exterior. Qualquer acontecimento que viesse atrapalhar o plantio e a comercialização da fruta símbolo da cidade virava logo motivo de preocupação do prefeito. Um desses, que provocou grande alvoroço, foi a terrível peste do soluço atípico que se abateu sobre a população.

Naquele dia, milhares de pessoas foram acometidas pelo horrível mal, e ninguém mais colhia bananas. Mesmo se alguém as colhesse, quem as transportaria até o porto? Mesmo se alguém as transportasse, quem as embarcaria nos navios? Se houvesse quem as embarcasse, que louco almirante permitiria que seu navio aportasse numa cidade empesteada, arriscando assim a saúde de sua tripulação? Foi dessa feita que o primeiro serviço de saúde da cidade foi montado e, tendo à frente o irredutível doutor Heráclito, conseguiu erradicar a horrenda doença.

Mas a cidade se transformava. A prefeitura passou a incentivar o surgimento de indústrias na região. Para isso, ergueu hidrelétricas, siderúrgicas e o que mais fosse necessário para desenvolver o então incipiente parque industrial. Em pouco tempo, não era mais preciso mandar vir de fora, como antigamente, os demais produtos que não fossem banana. Nas novas e robustas indústrias, os trabalhadores iam se organizando. Não só iam constituindo sindicatos, mas também faziam vaquinhas, se cotizavam para ajudar uns aos outros. Dessa caixinha saía uma ajuda para o trabalhador que ficava doente ou um amparo à viúva do colega morto em serviço. 
Num instante, o prefeito cresceu os olhos. Fez aprovar uma lei que colocava os sindicatos sob seu controle e também outra que controlava as caixinhas dos trabalhadores. Essas caixinhas cresceram e viraram uma grande rede. Só quem podia usá-la eram os trabalhadores que pagavam sua cota e seus dependentes. $O$ resto da população ficava a ver navios, à mercê da caridade alheia.

O controle dessa rede ficava muito distante dos trabalhadores, e os recursos angariados eram usados para pagar grandes hospitais privados, que lucravam enormemente com o sistema e não precisavam prestar conta a ninguém daquilo que faziam ou deixavam de fazer...

Até que um dia a população decidiu mudar tudo. 


\section{ESSE TAL DE SUS}

\section{NOSSA SOCIEDADE E A SAÚDE}

A sociedade brasileira tem sido marcada pela exclusão econômico-social e cultural. Os colonizadores portugueses massacraram os povos indígenas e para cá trouxeram, continuamente e por mais de dois séculos, enormes contingentes de pessoas originárias de alguns territórios da África negra, a fim de que, como escravas, produzissem as riquezas a serem apropriadas e acumuladas por alguns poucos. A abolição substituiu a escravidão pelo completo abandono daqueles que até então tinham sido escravos. Nesse período, os poucos médicos existentes se ocupavam em atender às elites, e a maior parte da população recorria às instituições de caridade ou à medicina popular, transmitida de uma geração para outra. De vez em quando, eclodia uma grande epidemia - de varíola ou de febre amarela - e muitas pessoas morriam. Quando alguns bem nascidos vinham também a morrer, as elites se assustavam e contratavam alguns médicos para atender à população.

Até que essas epidemias começaram a atrapalhar também a economia. Como exportar café para a Inglaterra, se os navios ingleses se recusavam a ancorar no porto do Rio de Janeiro com medo das doenças que acometiam a população da cidade? Em função disso, começaram a 
desenvolver campanhas para erradicar estas doenças, apesar do interesse ser mais econômico que social.

Com o desenvolvimento industrial, passou a ser dada certa importância à saúde dos trabalhadores. Em princípio, foram organizadas Caixas de Aposentadoria e Pensão (CAP), com finalidade de prover assistência médica e previdenciária. O financiamento ocorria por conta dos próprios trabalhadores, através dos descontos em seus salários, e dos empregadores. Mas essas caixas só existiam em algumas empresas e somente naquelas áreas econômicas em que os trabalhadores eram considerados "importantes". Nas zonas rurais, as pessoas continuavam à mercê das oligarquias locais, sem nenhuma sistemática de atenção à saúde.

A criação do Ministério da Educação e da Saúde Pública, em 1930, visava uma articulação nacional em saúde. Neste período, o Estado passou a tomar parte, e surgiram os Institutos de Aposentadoria e Pensão (IAP). Esses, em vez de serem organizados por empresas, eram vinculados a categorias: os ferroviários tinham o seu instituto, os bancários, o deles, e assim por diante. O financiamento passou a ser tripartite, ou seja, além dos trabalhadores e patrões, também o Estado deveria contribuir. No entanto, a gestão dos recursos foi ficando cada vez mais distante dos trabalhadores e mais a cargo do Estado. Como cada categoria tinha um poder de pressão diferente, a depender de sua "relevância" para a economia do país, os institutos eram também muito diferentes entre si, uns prestando melhores serviços e benefícios que outros. Ter direito à assistência médica era algo que dependia da inserção no mercado de trabalho. O projeto maior em saúde pública naufragou e reduziu a força dos movimentos sanitaristas anteriores.

Em 1966, todos esses institutos foram unificados no Instituto $\mathrm{Na}-$ cional de Previdência Social (INPS). Se, por um lado, houve certa uniformização nos benefícios; por outro, os trabalhadores perderam de vez a possibilidade de interferir na gestão - eram tempos de forte centralização e de feroz repressão a sua participação. 
O símbolo desse período foi o Instituto Nacional de Assistência Médica da Previdência Social (INAMPS), criado em 1974. Saúde não era um direito de todos. A assistência médica era um privilégio dos trabalhadores com carteira assinada. Quem não tivesse a "carteirinha do INAMPS" deveria procurar uma Santa Casa de Misericórdia ou outra instituição que aceitasse "indigentes". Mais: o grande beneficiado por esse sistema era o setor hospitalar privado, que atendia à clientela do INAMPS sem ser submetido a um controle rigoroso.

Observe que todo esse aparato estava voltado para a assistência médica curativa. Os problemas ditos de "saúde pública" - como o combate às endemias e a prevenção - eram tratados por outras instituições, vinculadas ao Ministério da Saúde, com menos recursos que as que se dedicavam à assistência médica, ligadas ao Ministério da Previdência e Assistência Social.

Esse era um modelo extremamente perverso, mas, como se vivia em uma ditadura, sua contestação era objeto de repressão. Enfim, o regime militar foi agonizando e a sociedade civil se reorganizando, culminando no movimento pelas "Diretas Já", em 1984. Dentre os movimentos sociais que surgiram nessa época, vamos destacar o movimento pela Reforma Sanitária.

O movimento pela Reforma Sanitária defendia a criação de um novo modelo de saúde, cujo delineamento foi traçado na Oitava Conferência Nacional de Saúde, ocorrida em 1986. Até então, as Conferências Nacionais de Saúde contavam apenas com a participação de técnicos e não provocavam grande impacto sobre o sistema de saúde. Contudo, com a Oitava Conferência foi diferente. Além de representantes do governo e profissionais de saúde, havia também representantes da população. O que foi discutido nessa conferência foi a criação de um novo sistema. As resoluções que de lá saíram foram incorporadas, na maior parte, pela Constituição, promulgada em 1988. 


\section{MAS AFINAL, COMO É ESSE NOVO SISTEMA?}

Existe uma frase na Constituição Federal, abrindo o artigo 196, que resume o espírito do SUS: "Saúde é direito de todos e dever do Estado". (BRASIL, 1988) Portanto, na Carta Magna está bastante clara a concepção de saúde que deve ser adotada. Tal documento aponta para a necessidade de que o Poder Público disponha sobre a regulamentação, fiscalização e controle deste sistema recém-nascido. Isto aconteceu dois anos depois, com a Lei Orgânica de Saúde (LOS) (Lei n. 8.080/90), que trata de toda a atenção à saúde no Brasil, seja no âmbito privado ou no público. A saúde, neste novo modelo, como detalhado no artigo $3^{\circ}$ da LOS, “[... tem como fatores determinantes e condicionantes, entre outros, a alimentação, a moradia, o saneamento básico, o meio ambiente, o trabalho, a renda, a educação, o transporte, o lazer e o acesso aos bens e serviços essenciais [...]”. (BRASIL, 1990a) Por fim, conclui que “[...] os níveis de saúde da população expressam a organização social e econômica do País". (BRASIL, 1990a) Ou seja, na lei, o processo saúde-doença é visto não apenas como um acontecimento biológico, mas como expressão de um conjunto de fatores sociais.

O SUS, como a própria sigla nos adverte, propõe-se a ser um sistema único. No modelo anterior, havia uma infinidade de instituições que se ocupavam da saúde, porém de forma descoordenada, muitas vezes sobrepondo funções, o que era muito pouco eficiente. Com o SUS, as instituições passam a ter um ordenamento comum, todas devem ser submetidas a uma mesma lógica. Existe o que se chama mando único em cada esfera de governo. Isso quer dizer que, no nível federal, quem deve coordenar as ações no campo de saúde é o Ministério da Saúde; no nível estadual, a Secretaria Estadual de Saúde; e no nível municipal, a Secretaria Municipal de Saúde. Mais adiante veremos quais as atribuições de cada um.

O SUS tem como diretrizes, segundo o artigo 198 da Constituição Federal: a "[...] descentralização, com direção única em cada esfera de 
governo; o atendimento integral, com prioridade para as atividades preventivas, sem prejuízo dos serviços assistenciais e a participação da comunidade". (BRASIL, 1988) Estas ficarão mais claras à medida que explicarmos os princípios do SUS. Vamos a eles.

\section{UNIVERSALIDADE}

Está escrito no inciso I do art. 7 da Lei n. ${ }^{\circ}$ 8.080/90 que um dos princípios do SUS é a "universalidade de acesso aos serviços de saúde em todos os níveis de assistência”. (BRASIL, 1990a) Ou seja, todas as pessoas têm o direito de usar os serviços de saúde, basta precisar. Isso pode parecer óbvio, mas é bom lembrar que nem sempre foi assim, bem como não é assim em todos os países do mundo. Há países em que o acesso aos serviços públicos de saúde só é permitido para as pessoas comprovadamente pobres. Aqueles que dispõem de recursos devem procurar serviços privados, pois o atendimento público não é entendido como um direito de todos os cidadãos, mas sim como uma "ajuda" do governo àqueles que não podem ser consumidores.

Há também países em que os serviços públicos de saúde são de exclusividade daqueles que contribuem através de descontos salariais, tal como acontecia no Brasil na época do INAMPS.

A transformação de um modelo para outro não ocorreu sem traumas. Imagine o cenário: havia uma rede de serviços que atendia aos trabalhadores do mercado formal - que nunca foram a totalidade dos trabalhadores. De repente, essa rede teve que atender a toda e qualquer pessoa que a ela recorresse.

Estamos, evidentemente, exagerando na caricatura, mas somente para tentar transmitir a dramaticidade da situação. Esse processo não ocorreu de uma hora para outra: mesmo antes do SUS, já havia uma série de modificações que visavam aumentar a cobertura dos serviços. Mas é preciso ter em mente que tudo isso ocorreu num espaço de tempo que historicamente pode ser considerado pequeno: o SUS só 
tem pouco mais de duas décadas, enquanto que o Brasil tem mais de 500 anos!

Nas últimas décadas, ocorreu um fenômeno que os estudiosos costumam chamar de universalização excludente. Enquanto o SUS incorporava aquelas camadas da população abandonadas durante séculos, os setores melhor organizados e remunerados "pulavam fora". Os trabalhadores com maior poder de negociação conseguiram obter planos de saúde particulares em seus acordos coletivos. Esse foi um setor que cresceu tanto que, na Pesquisa Nacional por Amostra de Domicílios, realizada em 2008, pelo Instituto Brasileiro de Geografia e Estatística (IBGE), estima-se que 26,3\% da população estavam cobertos por planos de saúde privados.

Isso pode ser considerado um enfraquecimento do SUS, porque representa a saída justamente dos grupos com maior capacidade de articulação, que poderiam se organizar exatamente para a melhoria da qualidade do serviço.

O que você acha da forma como as coisas aconteceram? Era inevitável? Poderia ter sido diferente? Como poderíamos ter mantido a ideia original de um SUS que fosse de todos, que todos usassem e que todos quisessem ver funcionar?

\section{INTEGRALIDADE}

No inciso II do art. 7 da Lei n. ${ }^{\circ}$ 8.080/90, está escrito que o SUS deve se pautar pelo princípio da "integralidade de assistência, entendida como conjunto articulado e contínuo das ações e serviços preventivos e curativos, individuais e coletivos, exigidos para cada caso em todos os níveis de complexidade do sistema". (BRASIL, 1990a)

Esse também é um grande diferencial entre o SUS e o sistema anterior. O INAMPS, criado em 1974, tomava para si a responsabilidade da assistência médica individual curativa, enquanto a prevenção e a atenção coletiva ficavam a cargo do Ministério da Saúde. Isso ocorria de 
forma completamente desconectada, uma instituição sem saber o que a outra estava fazendo.

Essa situação estava de acordo com uma forma de pensar da época, e que de certa forma ainda persiste, de que cura e prevenção, assistência individual e atenção coletiva eram coisas separadas, praticamente opostas entre si. Também havia a compreensão de que a assistência individual era lucrativa, portanto um rentável negócio a ser explorado, ao passo que a "saúde pública", que era como se chamavam as ações coletivas e preventivas, era assunto de abnegados ou comunistas, pois não dava dinheiro algum.

Hoje, percebe-se que não se pode estabelecer uma separação entre prevenção e cura. Há muitas ações que são ao mesmo tempo preventivas e curativas. A questão não é saber se estamos fazendo cura ou prevenção, mas sim o que cada pessoa precisa - este deve ser o foco.

Isso não quer dizer que cada unidade de saúde deva ter tudo o que uma pessoa precisa, mas sim que o sistema como um todo - todas as unidades, organizadas entre si - deva ser capaz de resolver tudo que as pessoas precisam. Isso nos leva a um outro princípio: o da resolutividade.

\section{RESOLUTIVIDADE}

No inciso XII do art. 7 da Lei n. ${ }^{0}$ 8.080/90, afirma-se que o SUS deve ter por princípio a "capacidade de resolução dos serviços em todos os níveis de assistência”. (BRASIL, 1990a) É o que se chama resolutividade. O sistema deve ser capaz de resolver o problema de saúde das pessoas que o procuram, qualquer que seja o grau de complexidade.

Isto significa que o mais simples dos postos de saúde deve ser capaz de tratar problemas complexos como, por exemplo, o tratamento de um câncer? Não, não é obrigatório que toda unidade de saúde tenha serviço de radioterapia para tratar câncer, pois, afinal, é um número relativamente pequeno de pessoas que precisam destes serviços para justificar sua existência em todas as unidades de saúde. Mas, uma unidade básica 
de saúde será resolutiva se, ao identificar uma suspeita de câncer, garantir o encaminhamento daquele paciente para uma unidade mais especializada. Só a perfeita sintonia entre as unidades mais especializadas e as básicas é capaz de conferir resolutividade ao sistema. Aliás, esta discussão sobre integralidade e resolutividade exige que apresentemos outro conceito: a descentralização.

\section{DESCENTRALIZAÇÃO}

O inciso IX do art. 7 da Lei n. ${ }^{\circ}$ 8.080/90 (BRASIL, 1990a) prevê a "descentralização político-administrativa, com direção única em cada esfera de governo: a) ênfase na descentralização dos serviços para os municípios; b) regionalização e hierarquização da rede de serviços de saúde".

Antes do SUS, as decisões que iriam afetar a saúde das pessoas eram fortemente centralizadas. De dentro das quatro paredes de um gabinete em Brasília, alguns técnicos decidiam construir um hospital psiquiátrico no Rio Grande do Sul, ou aumentar o número de leitos de uma maternidade no interior de Sergipe, ou conveniar mais dentistas em Roraima. Muitas vezes essas decisões não eram as mais condizentes com as necessidades da população. Mas como a população ia poder "palpitar" estando tão longe do centro das decisões? Como os técnicos poderiam ter uma exata dimensão da necessidade de tantas populações tão diferentes e tão distantes? Teriam mesmo que elaborar programas idênticos para todos os municípios do Brasil. São chamados programas verticais, pois já vêm prontos de cima para baixo.

A principal característica dos programas verticais é a de não haver espaço para quem vai executá-los - o município - poder participar do planejamento, tal como uma receita pronta que só precisa ser seguida pelos sistemas locais. Esta separação, entre quem faz e quem pensa, termina sendo extremamente prejudicial ao bom funcionamento do sistema.

É por isso que nos últimos anos tem acontecido o processo de municipalização da saúde, que é a ênfase na descentralização dos serviços 
para os municípios de que fala a lei. É muito mais fácil haver participação - que será o próximo princípio a ser analisado - quando as decisões ocorrem no município.

Quanto à hierarquização, é necessário explicar que se trata da organização do sistema por níveis de complexidade, especialmente no âmbito dos equipamentos à disposição da população. Nesta perspectiva, existiriam três níveis de complexidade: a atenção primária (ou básica), a secundária e a terciária. Esses três níveis devem estar perfeitamente articulados entre si.

O adjetivo "primário" engloba dois significados que apontam para perspectivas distintas. No sentido de "básico", "elementar", a atenção primária em saúde seria aquela destinada à questões de menor complexidade. Nos seus serviços trabalhariam profissionais de formação generalista voltados para a resolução dos problemas que exigem menos aparatos tecnológicos e, ao mesmo tempo, são mais comuns. Para isso, a atenção primária deve ser prestada por uma rede bem extensa de unidades básicas de saúde, de forma que sempre haja alguma unidade próxima a uma comunidade.

Quando se trata de "aquilo que vem antes", deve-se entender a atenção primária à saúde como porta de entrada no sistema. O usuário chega primeiro aos serviços de atenção primária, onde pode ser tratado de problemas comuns, como já dito; mas também onde a atenção à saúde vem antes mesmo da doença, com os programas de promoção e prevenção em saúde.

Na perspectiva hierárquica de atenção a saúde, o nível secundário envolveria atividades que requerem profissionais especializados e equipamentos de maior densidade tecnológica. É desenvolvido em centros de saúde, policlínicas e pequenos hospitais. Não se faz necessário que toda unidade de saúde ofereça atenção secundária, pois é um número relativamente menor de pessoas que irá ter esta necessidade. A rede secundária, portanto, não precisa ser tão extensa quanto a dos serviços primários. 
A atenção terciária seria aquela que exigiria profissionais bastante especializados e muitos equipamentos de alta complexidade, em geral bastante caros; é ofertada em grandes hospitais.

O sistema, portanto, poderia ser representado por uma pirâmide em que a base é a atenção primária, logo acima vem a atenção secundária e o topo é a atenção terciária. A maior parte dos problemas pode e deve ser resolvida pela atenção primária. Portanto, se um sistema tem a atenção primária bem estruturada, menos pessoas precisarão de atenção secundária e terciária.

O modelo anterior ao SUS conferia pouquíssima importância à atenção primária. Todos os interesses estavam voltados para a especialização, para o uso de alta tecnologia. Só que se um sistema se preocupar somente com a atenção terciária, não vai conseguir que nada funcione, nem mesmo os grandes hospitais, pois esses ficarão "inchados" de casos que poderiam muito bem ser resolvidos em unidades básicas por profissionais generalistas. Desta maneira, não se atenderiam bem nem os casos simples nem os casos graves.

Esta noção de complexidade, embora pareça adequada quando o que se está analisando é o maquinário envolvido e as instalações físicas, falha quanto à complexidade das estratégias de atuação utilizadas. Uma equipe de atenção primária em saúde deve se envolver na educação em saúde, conhecer os comportamentos e representações sociais de uma dada comunidade a respeito dos cuidados em saúde e elaborar estratégias de atuação naquele território, tudo isso com habilidades e competências de atuação psicológica e social por vezes mais complexas que técnicas de tratamento biomédico. Nesse sentido, os equipamentos de atenção primária não seriam apenas a porta de entrada no sistema. Suas equipes seriam responsáveis pelos usuários daquele serviço, independentemente de em qual nível do sistema ele se encontraria. Isto implica em realizar um papel de organizador de todo o sistema de saúde.

Já dissemos que um serviço primário é resolutivo quando consegue atender às necessidades dentro de seu nível de atenção e encaminhar 
para serviços especializados os casos mais complexos. Só que este encaminhamento precisa ser realizado corretamente. No que diz respeito à responsabilização pelo usuário, não se trata apenas de dizer que ele precisa de uma consulta de determinada especialidade e abandoná-lo à própria sorte. É necessário garantir seu atendimento no serviço especializado, informando a esse o histórico do problema de saúde da pessoa que será atendida. Isso é referência. Depois que o serviço especializado atende a pessoa, encaminha-a de volta ao serviço básico, informando o que foi realizado, se o problema foi ou não resolvido. Isto é contrarreferência.

A organização do sistema em atenção primária, secundária e terciária, a partir dos níveis mais básicos, com bons mecanismos de referência e contrarreferência, tudo isso confere hierarquização ao sistema de saúde. Mas esta organização ainda guarda a herança do tempo em que o tratamento era privilegiado, tanto no sentido de representá-lo como de maior complexidade, quanto no sentido de receber maiores somas de recursos.

Seja qual for o modelo de organização do sistema adotado, para que tenha resultado, é evidente que a população precisa conhecer seu funcionamento. É por isso que o inciso VI do art. 7 da Lei n. ${ }^{\circ}$ 8.080/90 (BRASIL, 1990a) defende a "divulgação de informações quanto ao potencial dos serviços de saúde e a sua utilização pelo usuário”.

\section{PARTICIPAÇÃO}

Para alguns, participação consistiria em fazer a população aceitar meIhor as propostas maravilhosas que os profissionais de saúde apresentam. Outros imaginam que participação seria a população assumir para si a execução de atividades que o serviço de saúde deveria fazer, mas como não faz... Nós entendemos que participar seria tomar parte no processo de decidir, de apontar problemas, de eleger prioridades, de definir modelos, de avaliar...

Em uma unidade básica de saúde, por exemplo, quando falamos em participar, não estamos falando apenas em assistir palestras em que os 
profissionais de saúde dizem como evitar doenças; ou tomar parte de reuniões em que os profissionais de saúde apresentam os programas de saúde, cabendo à população tão somente aprová-los ou, no máximo, pedir esclarecimentos. Muito mais do que isso, participar é levantar juntamente com os profissionais quais são os principais problemas, decidir por onde começar a enfrentá-los, definir o que se espera das ações de saúde e avaliar o que está sendo ou não alcançado.

O SUS prevê, no inciso VIII do art. 7 da Lei n. ${ }^{\circ} 8.080 / 90$, a participação da comunidade. (BRASIL, 1990a) Mais adiante detalharemos como ocorre essa participação e os foros garantidos na lei para exercê-la: os conselhos e as conferências de saúde.

\section{AUTONOMIA}

Afirma-se, no inciso III do art. 7 da Lei n. ${ }^{\circ}$ 8.080/90 (BRASIL, 1990a), que o SUS deve obedecer à "preservação da autonomia das pessoas na defesa de sua integridade física e moral". A autonomia é um princípio básico da bioética, isto é, a ética aplicada às questões que envolvem a vida.

Reconhecer a autonomia das pessoas implica em admitir que cabe ao usuário decidir, em última instância, se aceita ou não a intervenção que lhe é proposta. Para tanto, a pessoa deve estar de posse de todas as informações necessárias para tomar sua decisão - e o papel do profissional de saúde na provisão dessas é essencial. Mas, ressaltamos: informar a pessoa não se confunde com decidir por ela. É assim que, no inciso $\vee$ do art. 7 da Lei n. ${ }^{\circ}$ 8.080/90 (BRASIL, 1990a), é prevista a garantia do "direito à informação, às pessoas assistidas, sobre sua saúde".

\section{EQUIDADE}

A Lei n. 8.080 (BRASIL, 1990a) fala em "igualdade da assistência à saúde, sem preconceitos ou privilégios de qualquer espécie"; mas, o termo que tem sido consagrado é equidade. Equidade é diferente de igualdade. 
O princípio da igualdade considera que as pessoas têm direitos iguais às ações e aos serviços de saúde. Isso seria muito bom se vivêssemos numa sociedade em que todos tivessem as mesmas condições de vida, os mesmos riscos de adoecer e morrer. Acontece que a realidade não é assim. A sociedade está dividida entre os que têm muito, inclusive os meios para ter cada vez mais, e aqueles que a única coisa que têm é sua força de trabalho. Isso implica em grandes diferenças na qualidade de vida das pessoas. Está demonstrado que as pessoas com as maiores necessidades de saúde são aquelas que vivem em moradias sem saneamento adequado; que têm baixa escolaridade; que não têm alimentação balanceada; que trabalham em condições insalubres; que não têm segurança social. O processo saúde-doença se manifesta no indivíduo, porque é o indivíduo que adoece, porém a causa não está somente nele, mas também na maneira pela qual a sociedade se organiza. Não estamos dizendo que não seja um vibrião que cause cólera, mas sim que esse vibrião só causa cólera nas pessoas porque a sociedade não está organizada de modo a todas as pessoas terem acesso à água tratada e a um sistema de esgoto que funcione a contento. Assim, também é um bacilo que causa a tuberculose, mas esse bacilo só consegue causar a doença em pessoas já debilitadas, geralmente pessoas mal alimentadas e que vivem em habitações insalubres.

Podemos usar esse mesmo raciocínio em relação às doenças da boca. Assim, embora seja uma bactéria que produza o ácido que desmineraliza o dente, caberia pensar porque em determinados grupos sociais o processo acontece de forma bem mais avassaladora. Ora, é bom lembrar que o flúor é um elemento muito importante na prevenção e no controle da doença cárie - e o acesso ao flúor, infelizmente, ainda não é igualitário. Em muitas cidades, o flúor é adicionado à água encanada, mas nem todo mundo tem acesso à água encanada. 0 flúor também é acrescentado aos cremes dentais, mas existem famílias cujo orçamento doméstico não permite a aquisição desse item. Isso não 
quer dizer que todas essas ações - fluoretação da água e dos dentifrícios - sejam inúteis; ao contrário, elas são importantíssimas. Mas trabalhar com equidade significa "dar mais a quem precisa mais".

Devemos manter a fluoretação da água, das pastas de dente e programas preventivos nas escolas, mas, ao lado disso, devemos ter uma preocupação maior com as pessoas que não têm água tratada; que não podem comprar creme dental; que não estão nas escolas.

Vejam que, num simples exemplo, levantamos três problemas que influem na saúde sem serem internos ao setor saúde, são eles: saneamento, renda e educação. Isso nos leva ao conceito de intersetorialidade.

\section{INTERSETORIALIDADE}

No inciso X art. 7 da Lei n. ${ }^{0}$ 8.080/90 (BRASIL, 1990a), defende-se a "integração em nível executivo das ações de saúde, meio ambiente e saneamento básico".

Geralmente a administração pública encontra-se dividida em setores. Assim, nas prefeituras é comum encontrarmos secretarias de saúde, educação, urbanização, assistência social, administração, cultura, esporte, desenvolvimento, meio ambiente... A lista é extensa. Só que, enquanto a prefeitura tem secretarias, o município tem problemas - e na maior parte das vezes esses problemas precisam, para serem enfrentados, do envolvimento de várias secretarias. Um surto de leptospirose precisa da ação da secretaria da saúde, mas certamente envolverá também o saneamento, pois muitas vezes está relacionado com o destino incorreto do lixo, que não é apenas um problema de saúde, mas também ambiental.

Voltando àquele nosso exemplo. Para melhorar as condições de saúde bucal é preciso que o setor saneamento esteja funcionado bem, com todo mundo tendo acesso à água tratada e fluoretada. Políticas geradoras de emprego e renda e que diminuam as desigualdades sociais trarão inúmeros benefícios, um deles poderá ser o maior consumo de produtos 
de higiene oral - entre eles os cremes dentais, que devem ser fluoretados. Crianças fora da escola constituem um problema complexo, que passa não só pela oferta de vagas na rede de ensino público, mas também pela estrutura familiar, renda das famílias, entre inúmeros outros fatores.

É por isso que a intersetorialidade é necessária. Saúde, educação, meio ambiente, emprego e renda, e saneamento são interdependentes. Desta constatação resultou a formulação políticas saudáveis. Isso significa que as políticas de saneamento e as políticas de geração de renda, entre outras, devem promover saúde. Parece óbvio, mas nem sempre é o que acontece: a indústria de cigarros, por exemplo, gera muitos empregos; mas, será que esse benefício vale a pena em comparação à quantidade de mortes causadas pelo tabagismo?

\section{RACIONALIDADE}

Há dois incisos do art. 7 da Lei n. 8.080 (BRASIL, 1990a) que podem ser usados para explicar o princípio da racionalidade. O inciso XIII, "organização dos serviços públicos de modo a evitar duplicidade de meios para fins idênticos" e o inciso XI, "conjugação dos recursos financeiros, tecnológicos, materiais e humanos da União, dos Estados, do Distrito Federal e dos Municípios na prestação de serviços de assistência à saúde da população".

Para o SUS atingir a universalidade, a integralidade e a equidade, é necessário tirar o máximo proveito dos recursos financeiros existentes, daí decorre que a aplicação dos recursos precisa ser racional, evitando desperdícios.

Antes do SUS, como as instituições tinham pouca integração entre si, era muito comum haver vários serviços realizando as mesmas atividades para o mesmo público alvo. Isto é a duplicidade de meios para fins idênticos. Enquanto isto, outras populações ficavam descobertas.

Ao mesmo tempo em que se tenta evitar gastos desnecessários, a lei prevê a soma de esforços para alcançar os objetivos definidos, quando fala na conjugação de recursos dos níveis federal, estadual e municipal. 


\section{UTILIZAÇÃO DA EPIDEMIOLOGIA}

Uma disciplina que contribui para a racionalidade nos serviços de saúde é a Epidemiologia. Vejamos por quê.

Zélia Rouquayrol (1993, p. 7) define a Epidemiologia como sendo

[...] a ciência que estuda o processo saúde-doença em coletividades humanas, analisando a distribuição e os fatores determinantes das enfermidades, danos à saúde e eventos associados à saúde coletiva, propondo medidas específicas de prevenção, controle, ou erradicação de doenças e fornecendo indicadores que sirvam de suporte do planejamento, administração e avaliação das ações de Saúde.

Quando a Epidemiologia surgiu, ela consistia em contar quantas pessoas adoeciam ou morriam por determinadas doenças. Aos poucos novas abordagens foram sendo adotadas. No século XIX, por exemplo, a população da cidade de Londres era bastante acometida por cólera. Um médico chamado John Snow (1999) teve a ideia de investigar cada caso de cólera e verificar como era a distribuição dos casos no mapa da cidade. Descobriu que as pessoas que adoeciam de cólera eram as que recebiam água da mesma companhia de abastecimento. Essa empresa coletava água do rio num ponto que estava contaminado por esgotos; ao contrário da outra, cujos clientes não adoeciam. Dessa forma, John Snow concluiu que a cólera era transmitida pelo consumo de água contaminada, muito antes de ser descoberto o vibrião causador da doença. (HINO, et al. 2006) O que ele fez foi usar o que hoje se chama método epidemiológico: estudar a situação de saúde de um grupo de pessoas para chegar a conclusões a respeito de suas doenças.

Fica claro que a Epidemiologia é uma ciência aplicada cujos procedimentos provocam mudanças concretas na vida real: hoje não se tem mais epidemias de cólera em Londres, porque se passou a tratar a água.

Além de descobrir a distribuição e os fatores determinantes dos agravos à saúde, a Epidemiologia ajuda a planejar, administrar e avaliar 
serviços de saúde. Um exemplo: hoje em dia os municípios se preocupam em saber quantas crianças nascidas vivas morrem com menos de um ano. Isso é o coeficiente de mortalidade infantil, um indicador de saúde muito usado. Quando esse indicador está muito elevado, em geral significa que a população tem péssima qualidade de vida e que os serviços de saúde são pouco efetivos. Isso aponta para a necessidade de orientar o planejamento e a administração desses serviços. Depois de adotadas as medidas, este indicador auxilia a avaliar seu impacto.

A utilidade da Epidemiologia é juridicamente reconhecida, pois se lê no inciso VII do art. 7 da Lei n. ${ }^{\circ}$ 8.080/90 (BRASIL, 1990a): "utilização da epidemiologia para o estabelecimento de prioridades, a alocação de recursos e a orientação programática".

Entretanto, as informações epidemiológicas não devem ser tratadas como segredo de Estado. Devem ser divulgadas amplamente, inclusive para que funcione melhor a participação social. Como a população pode participar das decisões do sistema sem ter acesso a informações tão vitais?

Muitas vezes as informações epidemiológicas encontram-se no meio de tabelas complicadas e termos médicos difíceis de entender por quem não é da área. Neste caso, os profissionais de saúde têm a obrigação de traduzi-las para uma linguagem acessível.

Alguns princípios que foram explicados acima se referem à concepção do sistema e outros à forma de organizá-lo. Podemos entender que a universalidade, a equidade e a integralidade são princípios doutrinários, enquanto a regionalização, hierarquização, resolutividade, descentralização e participação popular são organizativos, pois, como afirma Caren do Espírito Santo (2012, p. 97) "visam dar racionalidade ao funcionamento do SUS".

\section{E OS SERVIÇOS PRIVADOS?}

Agora que já vimos os princípios que norteiam o SUS, pode surgir uma dúvida: como ficam os serviços privados? A Constituição Federal 
(BRASIL, 1988), no seu artigo 199, ao mesmo tempo em que cria o SUS, também resguarda que "a assistência à saúde é livre à iniciativa privada".

Os serviços privados podem ou não integrar o SUS, pois está previsto no art. 24 da Lei n. 8.080 (BRASIL, 1990a) que: "[...] quando as suas disponibilidades forem insuficientes para garantir a cobertura assistencial à população de uma determinada área, o Sistema Único de Saúde (SUS) poderá recorrer aos serviços ofertados pela iniciativa privada".

Entretanto, os serviços que forem contratados deverão seguir os mesmos princípios e diretrizes do SUS. Uma vez que o serviço é contratado, deve funcionar como uma parte articulada do sistema.

\section{CAMPOS DE ATUAÇÃO DO SUS}

O campo de atuação do Sistema Único de Saúde é bastante vasto, indo além da execução, gerenciamento e normatização dos serviços de saúde. São exemplos: a participação na formulação da política de saneamento, a ordenação da formação de recursos humanos na área da saúde; a formulação da política de medicamentos, a execução da política de derivados de sangue. Entretanto, há três campos de atuação que serão mais detalhados aqui: a vigilância sanitária, a vigilância epidemiológica e a saúde do trabalhador.

\section{VIGILÂNCIA SANITÁRIA}

A vigilância sanitária costuma ocupar espaço nos jornais quando aparecem manchetes do tipo: "Frigorífico interditado pelo serviço de fiscalização", ou ainda: "Novo lote de medicamentos falsificados descoberto”. De fato, estas são ações que envolvem a vigilância sanitária, mas sua abrangência é muito mais ampla. Uma definição que podemos usar é a que se encontra no parágrafo 1 do art. 6 da Lei n. ${ }^{0}$ 8.080/90 (BRASIL, 1990a): 
Entende-se por vigilância sanitária um conjunto de ações capaz de eliminar, diminuir ou prevenir riscos à saúde e de intervir nos problemas sanitários decorrentes do meio ambiente, da produção e circulação de bens e da prestação de serviços de interesse da saúde, abrangendo:

I - o controle de bens de consumo que, direta ou indiretamente, se relacionem com a saúde, compreendidas todas as etapas e processos, da produção ao consumo; e

II - o controle da prestação de serviços que se relacionam direta ou indiretamente com a saúde.

Ou seja, qualquer produto ou atividade que possa afetar a saúde das pessoas é objeto de preocupação da vigilância sanitária.

Fazer vigilância sanitária geralmente envolve dois processos: o de normatizar e o de controlar. O que é normatização? É o estabelecimento de regras que devem ser obedecidas na prestação de serviços ou produção de bens. Por exemplo, quando a Portaria 22/89 do Ministério da Saúde estipulou que os cremes dentais deveriam conter no mínimo 1000 e no máximo 1500 partes por milhão de flúor, isto foi uma normatização. Já o controle envolve a fiscalização dos bens, serviços e ambientes para verificar se as normas estão sendo cumpridas. Caso não estejam, há penalidades previstas em lei, que vão desde advertências e multas até a suspensão da venda do produto e interdição do estabelecimento.

Para dar a dimensão do universo abrangido pela vigilância sanitária, basta citar alguns exemplos pinçados da Portaria Ministerial n. 1.565/94, que define o Sistema Nacional de Vigilância Sanitária. Lá veremos que cabe a ele "vigiar" desde o saneamento básico até os medicamentos; desde os ambientes de trabalho até os serviços de assistência à saúde; os portos, os aeroportos, as fronteiras, a proteção do ambiente e, ainda, o sangue, os hemoderivados, as radiações e - ufa! - os alimentos, a água e a bebida que consumimos. 


\section{VIGILÂNCIA EPIDEMIOLÓGICA}

Todas as considerações que fizemos anteriormente sobre a importância da epidemiologia são úteis para explicar a vigilância epidemiológica. Airton Fischmann (1993) tem uma definição bastante simples: vigilância epidemiológica pode ser resumida como a obtenção de informação para ação. De fato, é disso que se trata: coletar e organizar informações sobre saúde e doença das pessoas para intervir com muito mais precisão.

Na Lei n. 8.080/90 (BRASIL, 1990a), a definição que se dá para a vigilância epidemiológica é a seguinte:

[...] um conjunto de ações que proporcionam o conhecimento, a detecção ou prevenção de qualquer mudança nos fatores determinantes e condicionantes de saúde individual ou coletiva, com a finalidade de recomendar e adotar as medidas de prevenção e controle das doenças ou agravos.

Você seria capaz de imaginar um médico que receita medicamentos sem antes fazer um diagnóstico? Pois essa situação absurda equivale a agir em saúde coletiva sem fazer vigilância epidemiológica.

Existem doenças que são de notificação obrigatória, isto quer dizer que toda vez que for dado um diagnóstico daquela doença, o serviço de vigilância epidemiológica deve ser informado. É o caso do sarampo, do tétano, da difteria... Se em uma determinada comunidade passam a surgir muitos casos de sarampo, mas a cobertura vacinal é excelente, chega-se à conclusão de que alguma coisa está errada: é preciso investigar se houve algum problema com a fabricação, o transporte ou a aplicação da vacina. Como esse problema seria detectado se não fosse a vigilância epidemiológica?

\section{SAÚDE DO TRABALHADOR}

O que diferencia a civilização da natureza intocada é que na primeira existe a marca do trabalho do homem. É através do trabalho que o 
homem transforma a matéria em coisas que passam a ter significado: trigo vira pão para alimentar, couro vira sapato para proteger os pés, árvores viram livros para espalhar ideias. Entretanto, o mesmo trabalho que modifica o mundo pode também afetar negativamente a saúde do trabalhador. Pense em operários da construção civil, digitadores, metalúrgicos, dentistas, motoristas, lixeiros, dançarinos, pilotos de avião, sapateiros e procure listar mentalmente as consequências que seus trabalhos trazem para sua saúde. Essas consequências são ocasionadas não somente pelos fatores biológicos, químicos e físicos; mas também pelas relações que se formam no trabalho, pelo modo como se organiza a produção, pelo grau de autonomia e realização do trabalhador.

Disso podemos deduzir que cada local de trabalho, com suas peculiaridades, afeta de modos diversos a saúde. É por isso que a saúde do trabalhador é incluída no campo de atuação do SUS. De acordo com o parágrafo três do art. 6 da Lei n. ${ }^{\circ}$ 8.080/90 (BRASIL, 1990a),

Entende-se por saúde do trabalhador um conjunto de atividades que se destina, através das ações de vigilância epidemiológica e vigilância sanitária, à promoção e proteção da saúde dos trabaIhadores, assim como visa à recuperação e reabilitação da saúde dos trabalhadores submetidos aos riscos e agravos advindos das condições de trabalho.

\section{COMPETÊNCIAS}

Já dissemos que no SUS deve existir direção única em cada esfera de governo. Ora, as esferas de governo são três: municipal, estadual e federal. São, portanto, três “direções únicas". Como elas podem estar organizadas de forma a não haver choque, sobreposição ou omissão?

Esta não é uma pergunta de fácil resposta. Na verdade, sua resposta vem sendo construída cotidianamente nestes mais de 20 anos 
de SUS. Na prática, ainda há muita dificuldade em conciliar as ações de municípios, estados e União obedecendo ao princípio da descentralização. Mas vejamos o que a Lei Orgânica da Saúde tem a nos dizer a respeito disso.

Dentre as competências do nível municipal, daremos destaque aos incisos I, II e IV do art. 18 da Lei n. ${ }^{0}$ 8.080/90 (BRASIL, 1990a), por considerarmos os mais representativos:

I - planejar, organizar, controlar e avaliar as ações e os serviços de saúde e gerir e executar os serviços públicos de saúde;

II - participar do planejamento, programação e organização da rede regionalizada e hierarquizada do Sistema Único de Saúde (SUS), em articulação com sua direção estadual;

IV - executar serviços:

a) de vigilância epidemiológica;

b) de vigilância sanitária;

c) de alimentação e nutrição;

d) de saneamento básico; e

e) de saúde do trabalhador.

Isso quer dizer que boa parte do processo de "botar a mão na massa" deve ser feito pelo município. Guido Ivan de Carvalho e Lenir dos Santos (1995, p. 85) têm uma frase excelente para exprimir a situação: "aquilo que o Município pode fazer, o Estado ou a União não deve fazer".

Portanto, nada mais natural que a primeira competência do nível estadual, figurada no inciso I do artigo 17 da Lei n. ${ }^{\circ}$ 8.080/90, seja: "promover a descentralização para os Municípios dos serviços e das ações de saúde”. (BRASIL, 1990a) Deve também o estado, segundo o inciso III do artigo 17, "prestar apoio técnico e financeiro aos Municípios" para que estes consigam assumir seus papéis. Quando o município ainda não está capacitado para realizar o que lhe cabe, então deve o estado "executar supletivamente ações e serviços de saúde". O estado deve ser "o promotor da harmonização, da integração e da modernização dos 
sistemas municipais", segundo as Normas Operacionais Básicas (NOB)1. (BRASIL, 1996)

Esse caráter harmonizador aparece quando se diz que a direção estadual deve "coordenar e, em caráter complementar, executar ações e serviços: de vigilância epidemiológica; de vigilância sanitária; de alimentação e nutrição; e de saúde do trabalhador". (BRASIL, 1990a)

A direção nacional do SUS, por sua vez, deve cada vez menos executar ações diretas e ater-se mais ao papel de grande orientador, traçando diretrizes gerais, definindo políticas e normas. Isso fica evidente nos incisos I, II, III e XIV do art. 16 da Lei n. ${ }^{\circ}$ 8.080/90 (BRASIL, 1990a):

$$
\begin{aligned}
& \text { I - formular, avaliar e apoiar políticas de alimentação e nutrição; } \\
& \text { || - participar na formulação e na implementação das políticas: } \\
& \text { a) de controle das agressões ao meio ambiente; } \\
& \text { b) de saneamento básico; e } \\
& \text { c) relativas às condições e aos ambientes de trabalho; } \\
& \text { III - definir e coordenar os sistemas: } \\
& \text { a) de redes integradas de assistência de alta complexidade; } \\
& \text { b) de rede de laboratórios de saúde pública; } \\
& \text { c) de vigilância epidemiológica; e } \\
& \text { d) vigilância sanitária; }
\end{aligned}
$$

XIV - elaborar normas para regular as relações entre o Sistema Único de Saúde (SUS) e os serviços privados contratados de assistência à saúde;

Assim como cabe ao nível estadual promover a descentralização para os municípios, também à direção nacional compete "promover a descentralização para as Unidades Federadas e para os Municípios, dos serviços e ações de saúde, respectivamente, de abrangência estadual e municipal" (BRASIL, 1990a) - art. 16, inciso XV. Para tanto, é necessário

1 Como a própria NOB diz, as Normas Operacionais Básicas definem as estratégias e movimentos táticos que orientam a operacionalidade do SUS. 
"prestar cooperação técnica e financeira aos Estados, ao Distrito Federal e aos Municípios para o aperfeiçoamento da sua atuação institucional" (BRASIL, 1990) - art. 16, inciso XIII.

\section{POR FIM...}

Neste capítulo, destrinchamos a Lei n. ${ }^{\circ} 8.080 / 90$, que nos diz como deve ser o SUS. Todos nós sabemos que entre o deve ser e o é sempre vai certa distância. Só que a descoberta desta distância caberá ao leitor. Procure conhecer melhor o sistema de saúde de sua cidade. Visite uma unidade de saúde e converse com profissionais e usuários. Tente perceber quais princípios do SUS estão sendo aplicados e quais não estão. O SUS existe de forma diferente em cada um dos mais de 5 mil municípios brasileiros, há lugares em que a experiência está dando certo; mas há casos onde ainda há muito o que mudar. Por que será?

Agora que você foi apresentado a esse tal de SUS, retorne à historieta de Musa Paradisíaca. Que semelhanças você percebe entre a fantasiosa narrativa e a história das políticas de saúde no Brasil? 


\section{HISTÓRIA - PARA FAZER PENSAR}

\section{A CIDADE DE LUZ NAS TREVAS}

Na cidade de Luz nas Trevas, quem mandava era uma tradicional família muito rica e poderosa: os Soares. Eram donos da maior parte das terras da região; da empresa que beneficiava os produtos agrícolas; das lojas que vendiam sementes, ferramentas, fertilizantes; dos armazéns que abasteciam a população.

O delegado era cunhado do patriarca; o padre, sobrinho; o diretor do hospital, irmão; e o prefeito - obviamente - era o filho. Isso já vinha há tantas e tantas gerações que as pessoas não se lembravam de nenhum dia em que as coisas não tivessem sido assim.

O prefeito mantinha a cidade sob seu controle, todo mundo ali, na rédea curta. Que ninguém ousasse discordar de nada! Mas, não se sabe como, certa insatisfação foi crescendo entre muitas pessoas da cidade. Uma vontade louca de poder opinar, discutir, influir. Questionar a concentração de poder nas mãos de tão poucos. Inquirir por que no hospital sempre faltavam medicamentos; por que as professoras do grupo escolar tinham que ganhar tão pouco; por que ainda morriam tantas crianças de sarampo e outras muitas levavam consigo o fardo da paralisia infantil, quando já havia vacinas para aquelas doenças.

O prefeito, que não era bobo nem nada, viu que se não agisse rápido a insatisfação poderia vir a se tornar algo muito maior e mais perigoso. Daí resolveu anunciar, com toda a pompa e circunstância, um novo modelo de administração: mais dinâmico, transparente e democrático. Assim, no hospital, na escola, nas áreas rurais, foram criados grupos comunitários. As pessoas participavam das reuniões, falavam de seus problemas à secretária de Ação Social, que sempre estava presente e dava preciosos conselhos: "Por que não organizar um mutirão para construir uma cacimba lá no distrito de Pitombeira?" 
Ela até conseguiria intermediar junto ao prefeito - que também era dono da loja de material de construção - a criação de uma linha de crédito para as pessoas poderem pagar o cimento em prestações bem pequenas...

Desse jeito iam surgindo as soluções: uma vaquinha para reformar o teto da escola, cheio de goteiras; um grupo de voluntários para limpar os terrenos baldios, frente a uma epidemia de dengue... Até que alguém, numa dessas reuniões noturnas, à luz de um lampião, perguntou:

- Mas se a gente precisa fazer todos esses trabalhos para ter saúde e educação, pra que é mesmo que serve o imposto que a gente paga? 


\section{PARTICIPANDO DO SUS}

Existe ainda outra diferença entre ações de saúde e outros bens produzidos que não falamos na discussão inicial. Ações de saúde não se realizam no vazio ou em objetos inanimados. Tradicionalmente se entendia que a ação de saúde seria realizada pelo profissional de saúde sobre um paciente - aliás, não é à toa que ele é chamado paciente! Mas, por mais passiva que seja a situação do paciente e por mais dono do poder que queira ser o profissional de saúde, nunca se pode retirar uma característica fundamental da ação de saúde: ela é uma relação humana, entre seres humanos. Exatamente por ser humano, o paciente nunca é inteiramente passivo: a ação de saúde também depende dele para acontecer. A produção de ações e serviços de saúde é imprescindível à interação entre prestadores e usuários de tais ações. Os serviços de saúde não podem ser produzidos na ausência do "consumidor" desses, ao contrário de mesas ou sapatos, que podem ser fabricados e estocados sem um consumidor, o qual só passa a ser necessário ao se fazer a comercialização destas mercadorias. Os usuários, então, são mais que meros "consumidores”, são também coprodutores destes serviços e ações. Disto resulta que a definição de necessidades e diretrizes no setor não pode ser monopólio dos "especialistas", mas devem ser partilhadas com os coprodutores dos serviços: os usuários. 
Por melhor e mais competente que seja o médico, o tratamento não terá sucesso se o paciente não cooperar em seguir as prescrições recomendadas. Ou seja, até mesmo na situação individual é necessário existir um mínimo de "participação" por quem "recebe" a ação de saúde.

Disso decorre que as primeiras vezes em que se começou a falar em participação nos serviços de saúde, o que se estava querendo dizer é que a população deveria aceitar mais docilmente as orientações que os profissionais de saúde faziam. Antônio Ivo de Carvalho (1995) nos conta que havia um entendimento de que as pessoas ficavam doentes por falta de informação de como tratar a água, de como escovar os dentes, de que alimentos consumir. A participação comunitária, como era então chamada, consistia no engajamento das pessoas que estavam marginalizadas da sociedade em atividades que diminuiriam as chances de adoecer: se não havia um sistema de esgotos, a participação da comunidade em um mutirão iria garantir a construção de fossas; se o lixo amontoado era um causador de doenças, um mutirão para seu recolhimento resolveria a questão. Era uma forma de lidar com esses problemas sem se perguntar: mas por que o Estado não investe em saneamento básico?

Houve um tempo em que a participação assumiu um caráter bem mais politizado, principalmente durante a Ditadura Militar. A participação popular tinha o objetivo de denunciar que a grave situação de saúde da população estava relacionada à forma injusta, exploradora e nada democrática como se organizava a sociedade. Participar implicava em lutar por coisas bem mais amplas do que aquelas com as quais a participação comunitária se ocupava, como liberdade de expressão, autonomia, poder para os trabalhadores.

A participação social geralmente se refere à institucionalização da participação. O que é isso? É a participação passar a ser regulamentada pelas leis, pelas instituições, pelos regimentos, por normas explicitadas. Enquanto na visão anterior a questão era atacar o sistema, nesta o sistema passa a aceitar que ocorra participação dentro dele. 
Usa-se muito o termo "controle social" como sinônimo de participação, uma vez que esta consistiria no controle que a sociedade faz sobre o Estado e os serviços que ele presta. Nenhum problema quanto a isso, desde que se faça uma ressalva: essa expressão também é bastante usada querendo dizer exatamente o contrário: o controle exercido pelo Estado sobre a sociedade, através de diversos instrumentos. Feita esta advertência, podemos falar em controle social sem o risco de sermos mal compreendidos. Para facilitar, usaremos o termo "participação social".

\section{CONSELHOS DE SAÚDE}

Existem diversas formas de a sociedade participar da gestão do SUS. Porém, por serem previstas em lei, as duas mais conhecidas são: as conferências de saúde e os conselhos de saúde. Inicialmente, as disposições sobre os conselhos e conferências de saúde deveriam fazer parte da Lei n. ${ }^{\circ}$ 8.080/90. Entretanto, os artigos que falavam tanto da participação social quanto do financiamento do sistema foram vetados pelo então presidente Fernando Collor. É por isso que estes dois assuntos se encontram na Lei n. ${ }^{\circ}$ 8.142/90, que afinal pôde ser aprovada alguns meses depois da Lei n. $8.080 / 90$.

É obrigatória a existência de conselhos de saúde em cada uma das três esferas de governo: municipal, estadual e federal. Mas nada impede que também se criem conselhos para um conjunto de municípios microrregião, um distrito sanitário ou para uma unidade específica de saúde, o que seria um conselho local.

Aliás, a organização de conselhos locais de saúde pode funcionar como um bom catalisador da participação social, porque é no debate do cotidiano de uma unidade de saúde que se aprende e se exercita a aventura de tentar práticas mais democráticas de organização dos serviços de saúde.

Os conselhos de saúde são órgãos em que um conjunto de representantes toma parte na gestão do SUS. Portanto, o gestor em saúde 
- que é o Secretário ou Ministro da Saúde, dependendo da esfera de governo considerada - não é o único a decidir sobre o que será feito em questões de saúde. Esses representantes são de segmentos diferentes: do governo e dos prestadores de serviço, de profissionais de saúde e de usuários. O conselho deve ser permanente, ou seja, deve se reunir com regularidade.

A Lei também diz que os conselhos de saúde devem ser paritários. Isto significa que metade dos conselheiros deve ser de representantes dos usuários. Quanto às demais representações, a Lei n. ${ }^{\circ} 8.142$ não esclarece seus percentuais, mas existe uma recomendação do Conselho Nacional de Saúde - resolução 33 de 23/12/92 - que propõe que 25\% seja de trabalhadores de saúde e $25 \%$ de prestadores de serviço, tanto públicos (governo), quanto privados.

Nesta mesma resolução se faz a sugestão de que "o número de conselheiros não seja inferior a 10 nem superior a 20 membros". (BRASIL, 1993) Evidentemente que isso se trata apenas de uma recomendação. O fundamental - e obrigatório - é manter a paridade.

O documento ainda enumera algumas entidades, que podem ser consideradas no momento de definir a composição do conselho, dentro do segmento de usuários:

- representante(s) de entidades congregadas de sindicatos de trabalhadores urbanos e rurais;

- representante(s) de movimentos comunitários organizados na área da saúde;

- representante(s) de conselhos comunitários, associações de moradores ou entidades equivalentes;

- representante(s) de associações de portadores de deficiência;

- representante(s) de associações de portadores de patologias;

- representante(s) de entidades de defesa do consumidor. 
Mas é bom lembrar que essas sugestões foram dadas pelos membros do Conselho Nacional de Saúde com base em certa experiência acumulada. Nada impede que, em um dado município, existam outras entidades bem mais representativas da sociedade ou que tenham um histórico no debate e enfrentamento das questões de saúde.

Uma advertência feita no documento é a de que os representantes dos usuários sejam indicados pelas suas entidades. Isto é de vital importância para que o conselho seja representativo de verdade. Infelizmente, algumas vezes isto não acontece. Há prefeitos que "elegem" quem deve ser o representante de cada entidade de usuários. Às vezes, os "representados" nem sabem quem é que os representa. Tudo isso compromete a participação social.

\section{E O QUE FAZ O CONSELHO DE SAÚDE?}

Raquel Dodge (1997) classifica as funções do conselho de saúde em três naturezas: deliberativa, consultiva e fiscalizatória. O dicionário define deliberar como "decidir ou resolver (algo) após discussão e exame". (DELIBERAR, 2012) De fato, quando a Lei n. ${ }^{\circ} 8.142 / 90$ art. 1 parágrafo 2 afirma que "o conselho de saúde [...] atua na formulação de estratégias [...] da política de saúde" (BRASIL, 1990b), o que se está expondo é uma função deliberativa do conselho de saúde.

Outro exemplo é o art. 37 da Lei n. ${ }^{8}$ 8.080/90 (BRASIL, 1990a), quando afirma que "o Conselho Nacional de Saúde estabelecerá as diretrizes a serem observadas na elaboração dos planos de saúde, em função das características epidemiológicas e da organização dos serviços em cada jurisdição administrativa". Além disso, segundo o artigo 26, "os critérios e valores para a remuneração de serviços e os parâmetros de cobertura assistencial serão estabelecidos pela direção nacional do Sistema Único de Saúde (SUS), aprovados no Conselho Nacional de Saúde".

O conselho de saúde também pode convocar uma conferência de saúde extraordinária. 
As funções consultivas de um Conselho de Saúde são igualmente importantes, ainda que um conselho não deva se contentar em desempenhar apenas este papel. Exemplos:

- propor adoção de critérios que definam qualidade e melhor resolutividade;

- "propor medidas para o aperfeiçoamento da organização do funcionamento do Sistema Único de Saúde (SUS) [...]”. (Brasil, 1993)

Quanto às funções fiscalizatórias, cabe ao Conselho de Saúde estar vigilante no que se refere a:

- "[...] recursos financeiros do Sistema Único de Saúde (SUS)" (BRASIL, 1990a);

- "[...] desenvolvimento das ações e serviços de saúde [...]”. (BRASIL, 1993)

\section{CONFERÊNCIAS DE SAÚDE}

Outra instância de participação social são as Conferências de Saúde. Enquanto os Conselhos são órgãos permanentes, as Conferências são eventos realizados a cada quatro anos ou, extraordinariamente, quando convocadas pelo Poder Executivo ou pelo Conselho de Saúde. Em função da periodicidade com que acontecem, sua finalidade é "avaliar a situação de saúde e propor as diretrizes para a formulação da política de saúde". (BRASIL, 19906)

As Conferências, tal como os Conselhos de Saúde, devem ser paritárias. A representação nas Conferências costuma ser ascendente: nas municipais são eleitos os representantes para as estaduais e nessas são tirados os delegados para a nacional. Um município muito grande pode ter, antes da Conferência municipal, Conferências distritais e locais. $O$ fato é que as Conferências permitem que um número de pessoas 
muito maior que o de conselheiros possa discutir e decidir sobre saúde. Apenas para ter uma ideia: da Oitava Conferência Nacional de Saúde participaram mais de 4 mil pessoas, das quais mil eram delegados - ou seja, com direito a voto.

\section{AS DIFICULDADES DO DIA A DIA}

Vimos como devem ser os Conselhos e Conferências de Saúde. Criar ou não um Conselho de Saúde não é uma opção do gestor, é sua obrigação. Recomenda-se que os conselhos sejam criados por uma lei própria, discutida e aprovada pelo poder legislativo da respectiva esfera de governo. Também é desejável que o Conselho se reúna com periodicidade, que conte com uma estrutura apropriada, tal como sala de reunião e funcionários. Isso porque, além das reuniões gerais do Conselho, existem também comissões internas que se propõem a estudar assuntos específicos, como orçamento e recursos humanos, por exemplo.

Gostaríamos de advertir que nem sempre o cumprimento de todas as exigências legais garante uma participação social efetiva. Muitas vezes o Conselho atende a todas as obrigações e recomendações, mas não toma para si, de fato, as funções deliberativas e fiscalizatórias. Não são raros os Conselhos de Saúde que se limitam a aprovar passivamente todos os projetos que o gestor encaminha - e que só os submete à votação quando obrigado. É comum não só conselheiros desconhecerem seu papel, como também gestores dificultarem a ação do conselho, não disponibilizando a informação necessária; não cumprindo cronogramas que permitam tempo para análise e debate das propostas; não efetivando as deliberações tomadas pelo conselho. Também é comum, o uso dos conselhos somente como forma de legitimar e dar uma aparência "democrática" à gestão.

Inúmeros Conselhos de Saúde cumprem apenas a formalidade da aprovação automática de planos de saúde, relatórios de gestão e projetos que se destinem à captação de verbas federais. Não é rara a 
indicação de conselheiros, que deveriam representar usuários, ser feita por prefeitos. São abundantes os casos em que gestores e profissionais de saúde monopolizam o controle da pauta. Tudo isso porque a institucionalização de mecanismos de participação social - Conselhos e Conferências de Saúde - não garante por si só a existência de uma participação social efetiva. O desafio, portanto, é muito maior que o de cumprir e fazer cumprir a lei: trata-se de tirá-la da frieza dos compêndios jurídicos e insuflá-la de vida, trazendo-a para o meio das pessoas.

\section{COMO FAZÊ-LO?}

Para tal não existe receita, mas alguns princípios podem ser levados em conta. Um deles poderia ser resumido da seguinte forma: se você quer que as pessoas participem, valorize o que elas têm a dizer. É muito comum os profissionais de saúde, do alto de seus conhecimentos técnico-científicos, desqualificarem as falas, as preocupações, as proposições dos usuários, perdendo assim a oportunidade de estabelecer um diálogo entre saberes que são diferentes, mas que se complementam.

Também é extremamente fácil a acusação de que as pessoas são desinteressadas, que não participam das reuniões. A experiência na área leva a pensar que as pessoas tendem a abandonar espaços de "participação" tão cedo percebem que suas decisões não são encaminhadas; que as informações necessárias à tomada de decisão não se encontram disponíveis; que a participação permitida se restringe a dizer sim ou não a propostas que chegam prontas. Outro ponto a salientar é a necessidade de que exista um efetivo vínculo entre o "representante" e os "representados", e que as posições defendidas no Conselho por aquele sejam discutidas com estes, a fim de que seja garantida a legitimidade da representação.

Por outro lado, há experiências riquíssimas de participação social verdadeira e com resultados. Há também gestores comprometidos com a qualidade do serviço, aos quais interessa que a população seja coautora do processo. 
E você? Conhece ou já ouviu falar do conselho municipal de saúde de sua cidade? Pense nas unidades de saúde que você já conheceu: elas têm conselho local de saúde? Quem são os conselheiros? Por que não tentar conhecê-los?

Torne a ler a história da cidade de Luz das Trevas. Como analisa a situação agora? É possível enxergar uma luz para as pessoas desse município? 


\section{HISTÓRIA - PARA FAZER PENSAR}

\section{PANACEIA}

O município de Panaceia tem 300 mil habitantes, é cortado pelo Rio Azul e pela Rodovia Vai com Tudo, que liga o interior do estado ao Porto da Muriçoca. Sua economia tem como base a produção de calçados e têxteis pelas indústrias situadas no polo industrial e no comércio, que aumentou sobremaneira com a construção do Porto, há cinco anos.

Em volta do polo industrial foi se desenvolvendo o bairro operário Vila Lisboa. O polo teve seu crescimento vinculado à oferta de incentivos variados, tais como isenção de impostos, energia e abastecimento de água gratuitos durante o prazo de 10 anos. Terminado este período, muitas indústrias têm se transferido para outros municípios, aumentando o desemprego local. Com a perda de seus empregos, muitos trabalhadores migram para a Favela do Cuscuz, situada às margens da rodovia Vai com Tudo. Do outro lado da Rodovia, foi construído o conjunto habitacional Berequetê, com a finalidade de cessar o problema das ocupações urbanas irregulares. Tal solução não ocorreu, visto que o processo de empobrecimento dos trabalhadores continuou.

Separada desses bairros pela Rodovia Senador Ambrósio Matos está a área nobre da cidade. O bairro que concentra maior renda é o de Beverly Hills. No entanto, encravada no coração da cidade, está a Favela Arco-Íris, área de antiga ocupação.

Nas proximidades da foz do Rio Azul, há uma área de preservação ambiental, em virtude do delicado equilíbrio ecológico do mangue. Esta área é, entretanto, alvo de uma desenfreada especulação imobiliária, que tem devastado o manguezal para construir condomínios fechados. Do outro lado do rio, o mangue é ameaçado pela Favela do Calango.

O bairro de Santo Antônio é uma tradicional colônia de pescadores, que já existia mesmo antes da fundação do município, há 60 anos. No 
entanto, a construção do Porto da Muriçoca diminuiu a quantidade de peixes, acarretando uma brutal perda de rendimentos dos pescadores.

No centro, está a maior parte dos serviços, tanto públicos quanto privados; bem como $90 \%$ do comércio da cidade. Palmeiral é um típico bairro de classe média. Do outro lado da estrada fica a região de Cavalariças, uma área com características predominantemente rurais, com várias chácaras e muitos sítios destinados à produção de hortifrutigranjeiros. Por fim, existe uma área habitada pelos índios taquara, que reivindicam sua transformação em reserva indígena.

A Secretaria de Saúde mantinha três unidades básicas de saúde: uma em Vila Lisboa, uma no conjunto Berequetê e outra no centro. Havia também quatro ambulatórios de pronto atendimento particulares, conveniados ao município e todos localizados no centro; dois hospitais estaduais: um no centro e outro na Rodovia Ambrósio Matos; e uma maternidade mantida pela ordem das irmãs Carolinas com contribuições da sociedade.

Todos os serviços de saúde, desde as unidades básicas até os hospitais, atendiam às pessoas que a eles procurassem; não estabelecendo uma população-alvo nem realizando planejamento das ações. A avaliação sempre se dava com base no número de procedimentos (consultas, internações, etc.), não havendo uma preocupação em verificar se aquelas atividades surtiam ou não um efeito real sobre a saúde das pessoas.

Foi então que uma nova equipe da Secretaria de Saúde começou a implementar uma reforma na saúde de Panaceia. Começou-se pelas unidades de Vila Lisboa e do conjunto Berequetê.

Na unidade do Berequetê, fez-se uma pesquisa para saber de onde vinham as pessoas atendidas. Constatou-se que somente pessoas do próprio bairro e de Cavalariças procuravam atendimento ali. Intrigada com o fato dos moradores da Favela do Cuscuz não virem procurar atendimento naquela unidade, a equipe pesquisou também a de Vila Lisboa. Seria lá que os moradores do Cuscuz procuravam atendimento? 
Não era. Em Vila Lisboa, somente a população do bairro procurava atendimento. O curioso: somente donas de casa e aposentados frequentavam a unidade. Onde estavam os trabalhadores e trabalhadoras do polo industrial, e os índios taquara, que residiam tão próximo?

Continuando a pesquisa, a equipe descobriu que era na unidade de saúde do centro que se consultavam os moradores da Favela do Cuscuz. Tudo isto porque a Rodovia Vai com Tudo é uma via de alto fluxo de veículos, não havendo passarelas para pedestres, ocorrendo muitos atropelamentos. Os habitantes do Cuscuz achavam menos arriscado frequentar a unidade do centro, um bairro muito melhor provido por linhas de ônibus.

Quanto aos operários das indústrias, foi constatado que eles não visitavam nenhuma unidade básica de saúde, pois essas só funcionavam em horário comercial, período no qual estavam nas fábricas. Em geral, estas pessoas aguentavam ao máximo seus problemas de saúde, até que, não suportando mais, iam durante o horário noturno aos ambulatórios de pronto atendimento.

Os moradores da Favela do Calango preferiam procurar os serviços do município vizinho, dado que moravam no limite do município e consideravam esses outros serviços melhores.

Por sua vez, os índios taquara não frequentavam nenhum serviço de saúde oficial, quer deste ou de outro município. Considerando que a medicina dos brancos não tinha respostas aos seus problemas, procuravam resolvê-los com suas próprias tradições. Não era incomum, por exemplo, ao serem internados nos hospitais, fugirem destes antes mesmo de obter alta.

Grande parte da população de Beverly Hills frequentava os serviços de Panaceia somente para obter imunização, pois preferiam buscar tratamento na capital do estado, distante $80 \mathrm{~km}$. No entanto, nos casos de grandes traumatismos, sobretudo nos acidentes de trânsito, era no hospital estadual de traumatologia que obtinham o primeiro 
atendimento. Este, por sinal, era o serviço público de saúde de melhor qualidade em todo o município.

FIGURA 1 - MAPA DE PANACÉIA

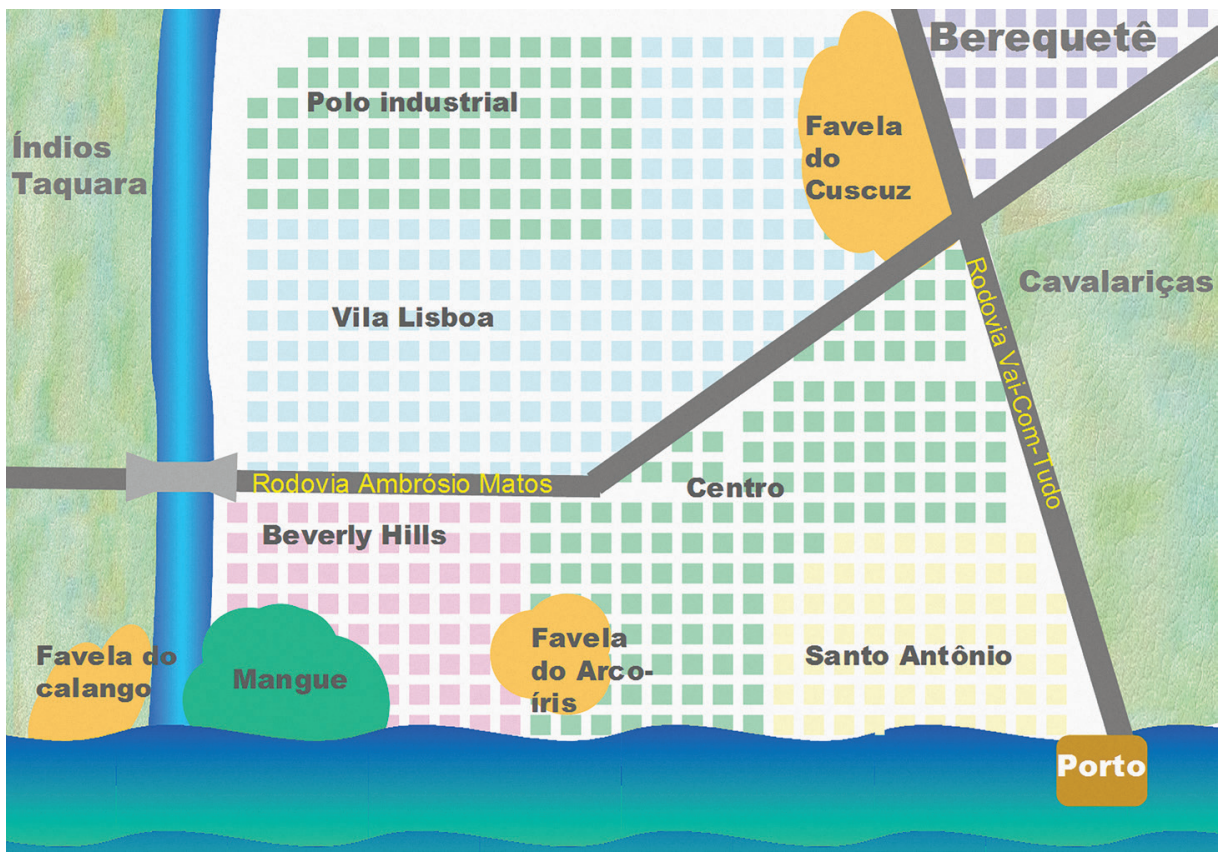

Fonte: Elaboração própria. 


\section{ORGANIZANDO O SUS}

\section{CAMPANHAS E PROGRAMAS}

Uma das primeiras formas de intervenção na saúde da coletividade foi a campanha. Campanha lembra o quê? Lembra exército, guerra: campanha militar. Campanhas de saúde eram ações que em muito lembravam campanhas militares: centralizadas, direcionadas contra um inimigo bem definido - uma epidemia, em relação às quais não cabia nenhuma contestação. Vamos lembrar um pouco de dois famosos campanhistas: Oswaldo Cruz, no Rio de Janeiro, e Rodolfo Teófilo, no Ceará.

Através do esforço de sua brigada mata-mosquito (atente bem para o nome: brigada), Oswaldo Cruz conseguiu eliminar a febre amarela no Rio de Janeiro. Seus homens lutavam contra águas paradas, cortiços insalubres. Rodolfo Teófilo, por sua vez, erradicou a varíola no Ceará por meio de uma campanha com vacinas que ele próprio fabricava.

A História registra que, tanto num caso como noutro, os objetivos sanitários imediatos foram alcançados. Porém, não sem atribulações. No Rio de Janeiro, a resistência da população à forma autoritária com que as pessoas eram tratadas desaguou na Revolta da Vacina. Indignada com as brigadas que Ihes invadiam as casas e derrubavam barracões, a população se insurgiu, tomou as ruas, quebrou bondes. No Ceará, 
Rodolfo Teófilo também encontrou resistência da população, mas principalmente do presidente da província.

Em geral, algum tempo depois da campanha, as epidemias voltavam aos locais de onde tinham sido erradicadas. É por isso que se adotou outra forma, também bastante antiga, de intervir na saúde da população: os programas. Enquanto as campanhas têm um caráter mais pontual, os programas se propõem a ser mais sistematizados, constantes, permanentes.

Desse modo, foram surgindo o programa da tuberculose, o programa da hanseníase (lepra), o programa da doença de chagas, e assim por diante. Cada programa tinha seu dispensatório, que era o local aonde as pessoas deveriam ir para receber o tratamento da doença em questão. Mais tarde, surgiu o centro de saúde, que reunia sob o mesmo teto os diversos programas existentes. Delineado assim esse quadro de organização das práticas de saúde, como poderíamos pensar outra estruturação dos serviços, de modo a conseguir fazer valer os princípios do SUS?

\section{DISTRITOS SANITÁRIOS}

A própria Lei n. 8.080 dá a dica em seu art. 10 parágrafo 2: "No nível municipal, o Sistema Único de Saúde (SUS), poderá organizar-se em distritos de forma a integrar e articular recursos, técnicas e práticas voltadas para a cobertura total das ações de saúde". (BRASIL, 1990a) É por isso que falamos em distritos sanitários. Mas o que vem a ser isto?

Se pensarmos que o sistema de saúde é composto por vários níveis de gestão, entenderemos, junto com Eugênio Vilaça Mendes (1995), que o distrito sanitário é a menor unidade operacional e administrativa, definida de acordo com critérios geográficos, populacionais, epidemiológicos, administrativos e políticos. Pensemos numa grande cidade: será possível dividi-la em setores com certa autonomia administrativa e certo grau de autossuficiência de infraestrutura. Poderá ocorrer de termos um município de médio porte onde o distrito sanitário abarca todo o município. Haverá também o caso de termos municípios vizinhos 
tão pequenos que eles, em conjunto, corresponderão a um único distrito sanitário. Colocado desta forma, fica mais fácil entender porque são também chamados Sistemas Locais de Saúde (Silos).

A organização do sistema de saúde em distritos sanitários permite uma hierarquia em atenção primária, secundária e terciária à saúde. Como foi dito no primeiro capítulo, a atenção primária deve estar sempre bem próxima à população. Um distrito sanitário deve ter um tamanho tal que seja possível manter uma boa gestão do sistema: nem tão grande, correndo o risco de perder contato com a realidade local; nem tão pequeno, que inviabilize a resolução de problemas mais complexos, merecedores de recursos mais especializados. Não há uma regra rígida para definir seu tamanho, mas Eugênio Vilaça Mendes (1995) cita a opinião de Tarino e Fowkes, para os quais a população de um distrito sanitário deve oscilar entre 100 mil e 300 mil habitantes.

No entanto, Eugênio Vilaça Mendes (1995) faz uma advertência que julgamos bastante oportuna: é preciso compreender o distrito sanitário como um processo social de transformação das práticas de saúde. Ou seja, não basta sair, burocraticamente, dividindo a cidade em setores, não se levando em consideração critérios demográficos, epidemiológicos, sociais, políticos e não se fazendo acompanhar de uma mudança no modelo de atenção à saúde.

Os profissionais de saúde precisarão, portanto, apropriar-se do território, isto é, conhecê-lo, saber como as pessoas vivem nele, que dificuldades encontram para ser saudáveis. Isto porque, como nos lembra Milton Santos (2000), entrevistado por Odette Seabra, o território é capaz de revelar as contradições que existem na sociedade, pois o uso que dele se faz depende do poder que se tem.

A esse processo chamamos territorialização. Cumpre descobrir: qual a acessibilidade dos serviços de saúde? Sim, pois o que determina o acesso das pessoas aos serviços é uma gama muito maior de fatores que a mera existência ou não de unidades de saúde. 
Existem diversas barreiras que podem se interpor entre as pessoas e os serviços. Essas barreiras podem ser geográficas: distâncias a serem percorridas, obstáculos a serem transpostos, por exemplo, um rio, um barranco. As barreiras também podem ser funcionais, ou seja, relativas ao funcionamento do serviço, tais como tipo e qualidade dos serviços prestados, dinâmica de agendamento, horários. Podem ainda ser culturais, significando uma distância entre hábitos, costumes, valores e crenças da população e a forma como operam os profissionais de saúde. Há também as barreiras de ordem econômica, que fazem com que determinados serviços não sejam acessíveis a certas parcelas da população.

Esse conjunto de obstáculos, somado a um rol de facilidades, irá influenciar a forma como a população se move em busca de serviços de saúde. Faça a seguinte experiência: passe um dia na porta de entrada de uma unidade de saúde, perguntando aos usuários de onde eles vêm. A seguir, localize no mapa os locais enumerados: você será capaz de visualizar a área da qual provém as pessoas que procuram o serviço. A isso chamamos de área de influência. Perceba que este conceito se relaciona à lógica da livre demanda.

Por outro lado, vamos imaginar que o sistema de saúde tenha passado por um processo de distritalização. Isso significa que os serviços de saúde agora passam a operar segundo a lógica do território. Cada unidade de saúde circunscreverá uma área cuja população será de sua responsabilidade. Isso é o que chamamos de área de abrangência. O ordenamento, agora, é conferido pelo planejamento em saúde.

Até o momento, já fizemos dois recortes no território: o distrito sanitário (território-distrito) e a área de abrangência (território-área). Pois bem, dentro do território-área, costuma haver disparidades de condições de vida da população. Se formos dividi-la em áreas menores, mais ou menos homogêneas, encontraremos o território-microárea. São as microáreas que desvelam a desigualdade dos níveis de saúde, permitindo ao serviço planejar suas ações norteado pela equidade. 
Uma das formas de colocar em prática os conceitos dos distritos sanitários é através do Programa Saúde da Família (PSF). Queremos ressaltar que o PSF é apenas uma das formas, não a única, de se apropriar do território. Vamos explicar um pouco este programa tomando por base as portarias 1886 de 18 de dezembro de 1997, 1348 de 18/11/1999 e 157 de 19/12/1998 do Ministério da Saúde. Vale lembrar que portarias são mecanismos bem menos perenes que leis, de forma que costumam ser atualizadas frequentemente. Daí porque nos reportaremos somente aos aspectos mais gerais: aqueles que tiverem interesse deverão procurar as normalizações mais recentes.

Antes de apresentar o PSF, parece oportuno falar do Programa de Agentes Comunitários de Saúde (PACS). Nesse, pessoas com formação básica recebem capacitação em questões de saúde, tais como o incentivo ao aleitamento materno e o combate à diarreia com o soro caseiro de reidratação oral. Esse trabalho simples, mas de extrema importância, contribuiu para reduzir a mortalidade infantil em vários municípios e inspirou a criação do PSF, por meio da incorporação de mais profissionais à equipe.

\section{PROGRAMA SAÚDE DA FAMÍLIA}

O PSF acontece dentro do SUS, portanto todos os princípios explicados no primeiro capítulo devem ser observados no PSF. Mas, além destes princípios básicos, há características operacionais que o distinguem de outras formas de colocar o SUS em prática.

No Brasil, antes do Ministério da Saúde lançar o PSF, em 1994, já havia municípios e estados que trabalhavam na lógica da Saúde da Família. Atualmente, é possível encontrar experiências municipais ou estaduais que diferem do que é proposto pelo Ministério da Saúde. Contudo, vamos nos ater à discussão acerca da elaboração do ministério, ressalvando que não é a única sobre o assunto. Eis as características operacionais do programa: 


\section{CARACTERISTICAS OPERACIONAIS}

Adscrição: o nome pode ser feio, mas o significado faz uma grande diferença nas práticas de saúde. A Portaria n. 267/GM de 6 de março de 2001 do Ministério da Saúde fala em "adscrição da população sob a responsabilidade da unidade básica de saúde”. (BRASIL, 2001b) O que vem a ser isto?

No cenário anterior que descrevemos sobre práticas de saúde, uma característica marcante dos programas era uma indefinição de quem era a população alvo de cada serviço. Em geral, o que acontecia era a livre demanda.

Livre demanda é uma forma de organizar o serviço de saúde na qual é necessário que o paciente chegue à conclusão de que precisa desse e decida procurá-lo. Ora, nem todo problema de saúde é percebido pelo paciente, assim como vários são os obstáculos que podem desmotivá-lo a buscar o serviço.

Os serviços atendiam, na verdade, a "quem aparecesse". Mas, e os que não apareciam? Será que não precisavam do serviço? Ou não o procuravam desmotivados pela dificuldade de acesso? Será que sequer sabiam se precisavam do serviço?

Adscrever uma população a um serviço significa dizer: "estas pessoas são responsabilidade deste serviço". Seus problemas de saúde passam a ser problemas do serviço de saúde.

É o que acontece com o PSF. Cada agente comunitário de saúde é responsável por um máximo de 750 pessoas. Cada equipe de saúde da família deve ser responsável por, no máximo, 4 mil pessoas, sendo que a Portaria n. ${ }^{\circ}$ 2.488/2011 do Ministério da Saúde recomenda a média de 3 mil pessoas. Dentre essas, há algumas saudáveis e outras doentes; umas nascendo e outras morrendo. $O$ agente de saúde acompanha cotidianamente todas elas, conhece suas casas, seus problemas, sua maior ou menor chance de adoecer. Aquelas com maiores chances de adoecer, ou em situação especial, recebem atenção redobrada. Tão logo fica sabendo que uma mulher da população sob sua responsabilidade está 
grávida, o agente de saúde passa a encorajá-la a manter o pré-natal em dia. É bastante diferente da situação anterior, em que a gestante seria obrigada a saber que deveria buscar o serviço e ir atrás de seu atendimento. A adscrição da clientela, ao lado do planejamento em saúde, vai permitir que um dos princípios do SUS seja respeitado: a equidade.

Quando um serviço se orienta pela livre demanda, os primeiros a serem atendidos são os que mais cedo chegarem ao local, para conseguir um lugar na fila. Quando há a delimitação da população que é de responsabilidade do serviço e um planejamento em saúde que tome como subsídio as condições de vida desta população, é possível direcionar maiores esforços aos grupos que mais precisam.

Mas, atenção: quando não há racionalidade, a adscrição pode virar uma "cerca". Se o serviço define como sendo de sua responsabilidade tantas mil famílias, mas ao lado destas há outras tantas que não são de responsabilidade de ninguém, o que deveria funcionar como um organizador do sistema vira uma perversa forma de exclusão - e isso agride o princípio da universalidade.

A Portaria 1.348 de 18/11/99, em seu art. 2 inciso I, fala que o PSF deve ter "caráter substitutivo das práticas tradicionais exercidas nas unidades básicas de saúde”. (BRASIL, 1999) Isso significa que o PSF não é "mais um programa" ao lado de tantos outros. Ele deve substituir os outros programas. Vamos tomar o seguinte exemplo: numa unidade de saúde existe o programa da hipertensão, o programa da tuberculose, o programa da hanseníase, o programa de incentivo ao aleitamento materno, cada qual com sua lógica própria. Implantar o PSF numa unidade como essa não significa "acrescentar" uma equipe de PSF que iria trabalhar paralelamente a todos estes programas. Significa, isto sim, que todas essas atividades passam a ser executadas dentro da lógica da abordagem à família pela equipe de PSF.

Disso deriva outra característica operacional do PSF fortemente inspirada num princípio do SUS presente na Portaria 1348 de 18/11/99, art. 2 inciso III (BRASIL, 1999): "integralidade da assistência prestada à 
população adscrita". Ora, a equipe de saúde da família é uma equipe de profissionais generalistas direcionados para a atenção primária. Como então se pode querer que haja integralidade? Através da referência e contra referência. É nesse ponto que muitos municípios experimentam um estrangulamento: não conseguem garantir o acesso à atenção secundária e terciária a partir de suas unidades de saúde da família. Este é um erro grave. Ofertar somente a atenção primária sem garantir a secundária e a terciária pode levar ao descrédito do programa, fazendo com que a população prefira enfrentar as filas dos grandes hospitais a buscar uma unidade de saúde da família. Eugênio Vilaça Mendes costuma dizer que o PSF deve ser o primeiro contato do usuário com o sistema de saúde, salvo nas ocasiões de urgência e emergência. Assim, lê-se no inciso IV: "garantia da referência e contra referência aos serviços de maior complexidade do sistema de saúde". (BRASIL, 1999)

No inciso $V$, afirma-se que o núcleo central de abordagem é a família. Tradicionalmente, as práticas de saúde olham para o "paciente" como se este não estivesse inserido numa sociedade, em grupos sociais. Enxergam somente o indivíduo ou, o que é mais grave e mais frequente, veem apenas pedaços deste indivíduo: o fígado, o rim, o dente. Ter uma abordagem centrada na família já é um avanço em relação a essa prática fragmentada, porque compreende que o indivíduo está inserido, originalmente, neste grupo social primário. Assim, torna-se possível perceber que aquela criança com desnutrição e que não recupera peso, na verdade, é parte de uma família que está submetida a uma estrutura causadora de doenças, embora cada membro manifeste de forma diferente.

Uma das formas de concretizar essa abordagem é a utilização do prontuário familiar. As informações sobre saúde dos membros de uma mesma família são guardadas em conjunto. Mas, mais importante do que uma estrutura física, como um arquivo de prontuários, é que os profissionais estejam aptos a pensar a partir desse referencial.

É por isso que, no inciso $X$, fala-se em educação permanente dos profissionais integrantes das equipes de saúde. Mudar um modelo de 
atenção à saúde pode até requerer modificações na estrutura física, mas o eixo das transformações é o conjunto de pessoas que nele trabalham.

Sobre recursos humanos, é bom lembrar da abordagem multiprofissional. Existe uma equipe mínima prevista pelo Ministério da Saúde: agentes de saúde, auxiliar de enfermagem, enfermeiro, médico e, mais recentemente, dentista, atendente de consultório dentário e técnico de higiene dental. Esta, no entanto, é uma equipe mínima; os municípios que decidirem incluir outros profissionais podem fazê-lo.

Algumas características operacionais apontadas pela portaria não são nada mais que reafirmações dos princípios do SUS (BRASIL, 1999), como o "estímulo à ação intersetorial", inciso VIII, "estímulo à participação e ao controle sociais", inciso IX, e "estímulo a ações de promoção da saúde", inciso VII; ou apontam na perspectiva da maior racionalidade: "instrumentos permanentes de acompanhamento e avaliação das ações realizadas", inciso XI. A respeito da expressão "promoção de saúde", cabe abrir um parêntese para explicar melhor este termo, que tem sido bastante usado e, por vezes, abusado. Será dedicado um tópico à promoção da saúde neste capítulo, mas o assunto será mais detalhado no capítulo seguinte.

\section{PROMOÇÃO DA SAÚDE}

Existem muitas palavras que, dependendo da intenção de quem as utiliza, significam coisas diferentes. Como exemplo, temos a palavra "moderno". Temos a arte moderna em contraposição à arte clássica. Podemos também, ao dizer que algo "é o que há de mais moderno", estar fazendo referência a um avanço tecnológico. Da mesma forma, há quem diga que moderno é privatizar serviços públicos e cortar investimentos nos setores sociais. Como se vê, cada um usa a palavra de acordo com suas conveniências.

Do mesmo jeito acontece com a expressão "promoção de saúde". Esse é um termo que muitas pessoas têm empregado com significados 
bastante diferentes. Vamos agora trabalhar uma das concepções de promoção de saúde.

Em 1986, a Organização Mundial da Saúde fez um grande encontro na cidade de Ottawa, no Canadá: a Primeira Conferência Internacional sobre Promoção de Saúde. Já havia um tempo em que pessoas de toda parte do mundo vinham achando que os problemas de saúde não se resolveriam apenas com mais assistência médica: mais hospitais, mais leitos, mais remédios, mais internações. Tudo isso é muito importante, mas não é suficiente para fazer com que as pessoas sejam saudáveis. Porque todas essas coisas só atuam no lado da doença. É como estar a vida toda enxugando o chão embaixo de uma torneira que pinga, sem nem sequer pensar em consertá-la - ainda que enxugar o chão seja algo também importante, mas não suficiente.

Então nessa conferência foi elaborado um documento que ficou conhecido como Carta de Ottawa. Nela se diz que: "Promoção de saúde é o nome dado ao processo de capacitação da comunidade para atuar na melhoria da sua qualidade de vida e saúde, incluindo uma maior participação no controle desse processo". (PROMOÇÃO, 1996, p. 11)

Observem que se fala de capacitação da comunidade, isto é, tornar capaz. A comunidade capacitada é a comunidade que se faz sujeito, que não fica na situação de objeto. Quando somos objeto? Quando deixamos que decidam por nós o que devemos fazer ou o que é melhor para nós. Então, percebam como é complexa a promoção de saúde, pois essa exige uma mudança muito profunda de posicionamento perante a vida, ou seja, passar da condição de espectador para a de protagonista, de ator.

O papel dos trabalhadores de saúde é facilitar esse processo. Eles não seriam os "donos" de um conhecimento infalível que seria "dado" - ou algumas vezes imposto - para pessoas-objeto, pessoas sem história, sem saberes, sem vontade própria. Sua tarefa é tornar possível às pessoas fazer uso de tudo que for necessário para melhorar sua qualidade de vida. Esse "tudo que for necessário" poderá ser seus estudos de profissionais de saúde, mas não será só isso; será também a cultura, 
a história da comunidade. Quando se fala que as pessoas farão uso do saber dos profissionais, esse saber deixa de ser só deles. Afinal, o conhecimento do profissional de saúde é o conhecimento que a humanidade construiu ao longo das gerações, sempre que procurou resolver seus problemas de saúde. Não faz o menor sentido achar que esse conhecimento, só porque tiveram a oportunidade de ter acesso a ele, é propriedade deles. Ele é tão deles quanto de qualquer ser humano, porque é um legado, uma herança deixada por aqueles que viveram antes de nós. Quanto ao saber próprio da comunidade, o que é? É também uma herança, só que produzida e transmitida de um jeito diferente: enquanto o saber do profissional de saúde é produzido através do método científico e transmitido nos cursos e universidades; o saber da população é construído pela experiência e transmitido pela tradição oral. Às vezes, o próprio saber científico "descobre" algo que o saber popular já conhecia há muito tempo - como é o caso de muitas plantas medicinais que a população usa e a ciência comprova o efeito.

Os profissionais de saúde sabem muito sobre como acontecem as doenças na boca. Sabem como se forma a placa bacteriana e os prejuízos que ela causa ao dente - a cárie - e à gengiva - as doenças periodontais. Sabem que as bactérias presentes na placa bacteriana utilizam o açúcar dos alimentos para produzir ácidos que atacam o esmalte. Que as toxinas produzidas pelas bactérias danificam o tecido gengival fazendo com que o dente perca sustentação. Mas a população também sabe algo sobre dentes e gengivas. Afinal ela vê essas coisas acontecendo. Muitos profissionais de saúde nunca se preocuparam em saber como a população explica essas coisas, como ela entende. Afinal, é muito mais fácil dizer que a população é ignorante. É fácil, mas não resolve. Enquanto persistir nessa postura de desconsiderar o saber popular, o profissional não estará conseguindo contribuir para o processo de capacitação da comunidade, portanto estará bem longe da promoção da saúde.

É bastante comum utilizar o termo "promoção da saúde" como sinônimo de prevenção. Prevenir a ocorrência das doenças é muito 
importante, é uma das tarefas mais nobres dentre as que os profissionais de saúde podem se ocupar, mas promoção de saúde é mais que isso, porque vai além da assistência médica. Isso, contudo, não quer dizer que os profissionais de saúde não possam fazer promoção de saúde. Podem sim, articulando-se com profissionais dos outros setores, atuando junto à população para que ela seja mais dona de sua história, trabalhando, enfim, para a gente ser feliz.

66

É, parece que o desafio colocado não é pequeno.

Voltemos a tratar do município de Panaceia. Nota-se que sua população encontra várias dificuldades para acessar os serviços de saúde. Que barreiras você identifica e de que tipo? Quais as áreas de influência de suas unidades de saúde? O que seria necessário fazer para começar a organizar o município na lógica dos distritos sanitários? 


\section{HISTÓRIA - PARA FAZER PENSAR}

\section{CARNAUBEIRA DO NORTE}

O município de Carnaubeira do Norte é um desenvolvido polo industrial, distando 500 quilômetros da capital do estado. A cidade nasceu há 145 anos com marcada vocação para o comércio, sendo facilitador o fato de estar no centro da rota de transporte da cera de carnaúba, um produto que já foi a grande riqueza da região. Aos poucos, pequenas manufaturas foram se aglomerando e mais tarde a indústria local contou com fartos incentivos fiscais e pesados investimentos em infraestrutura, bancados por uma agência de desenvolvimento regional.

O município conta hoje com 1,5 milhão de habitantes, encontrando-se $80 \%$ desses na zona urbana. Na zona rural, predomina a pecuária bovina para abate. Seu maior problema atual reside no crescimento desordenado, agravado pela forte imigração de pessoas da região circunvizinha, tangidas pela derrocada do ciclo da carnaúba e atraídas pela promessa de emprego nas indústrias.

Carnaubeira do Norte tem 50 mil famílias vivendo próximo a encostas ou nas margens do Rio Barreão, isto é, em situação de risco. Na época das chuvas, em virtude de cheias e alagamentos, ocorrem muitas mortes.

Outro grave problema de Carnaubeira do Norte é a violência urbana. Com vistas a reprimi-la, o prefeito decidiu ampliar a guarda municipal e dotá-la de armamentos. Foi realizado um concurso público para admitir 5 mil novos guardas que, após treinamento, foram encarregados de fazer rondas pelos bairros da cidade. A criminalidade diminuiu em 17\%.

Face à admissão dos novos guardas, o prefeito viu-se com problemas relacionados à Lei de Responsabilidade Fiscal. Como a referida Lei estabelece um teto máximo de recursos a serem gastos com o funcionalismo público, tornou-se necessário realizar demissões em outros setores considerados menos importantes. A solução encontrada foi 
demitir todos os médicos, enfermeiros, dentistas e agentes de saúde do município. Com isso, a rede de serviços de saúde ficou ociosa, ao passo que as necessidades da população restaram sem ser atendidas.

Em consequência, houve uma grande procura por planos privados de saúde e um decorrente aumento na arrecadação de impostos sobre o faturamento destas empresas. A administração municipal considerou isto um fato extremamente positivo; pois o que antes era uma fonte de despesas, tornou-se uma importante fonte de receitas. Isto era excelente para alcançar o superávit financeiro do município, tarefa número um do secretário de finanças.

Infelizmente, restava uma substantiva parcela da população que ainda não aderira aos planos de saúde. O governo municipal tentou de todas as formas incentivar o consumo desses serviços, mas todas as campanhas educativas redundavam em fracasso. Por fim, decidiu-se contratar um grupo de consultores estrangeiros para solucionar o problema. Após diversas pesquisas, os consultores descobriram que o fenômeno ocorria porque $40 \%$ da população estava situada abaixo da linha de pobreza, não tendo, portanto, poder aquisitivo para comprar esses serviços.

A proposta elaborada pelos consultores foi a criação do Programa Amigos do Hospital. Nesse programa, voluntários eram arregimentados para trabalhar gratuitamente nos serviços de saúde. Para ter acesso aos serviços, a população deveria passar por uma triagem socioeconômica, a fim de evitar que pessoas que pudessem pagar planos de saúde usassem o serviço. Uma grande rede de TV deu maciço apoio ao projeto, inserindo chamadas em sua programação. 


\section{PROMOVENDO A SAÚDE'}

Aqueles que transitam entre profissionais de saúde já devem ter ouvido bastante a expressão "promoção de saúde". Como já dito, esse termo é usado em tantos contextos e com tantos sentidos, que às vezes parece que as pessoas se referem a coisas diversas.

Se recorrermos ao dicionário, veremos que a palavra promover está definida como "dar impulso a; favorecer o progresso de; fomentar; trabalhar a favor de" ou ainda "ser a causa de". (PROMOVER, 2012) Logo, há variadas acepções de promoção da saúde simplesmente porque há distintos entendimentos sobre o que venha a ser saúde ou sobre como ela pode ser promovida. Atente-se que, quando se diz que promover significa causar, a pergunta fica então recolocada da seguinte forma: o que causa saúde? O que causa doença? Disso decorre que, para se discutir o conceito de promoção de saúde, é necessário discorrer sobre a polissemia do termo "saúde".

As explicações que as pessoas dão ao se referirem à saúde sempre sofrem a influência do momento histórico em que estão vivendo, da posição que ocupam na sociedade. É por isso que a causalidade das doenças

1 Adaptado do documento elaborado com a finalidade de subsidiar oficinas de trabalho em saúde bucal da Secretaria da Saúde do Ceará. (BLEICHER, 2001) 
tem historicidade. ${ }^{2}$ Por ora, será suficiente contar que um grande marco aconteceu no Renascimento: o surgimento do método científico.

O que chamamos de método científico é um conjunto de regras embasadas na lógica e na experimentação, pelo qual buscamos conhecer a realidade. O exemplo máximo dessa racionalidade é a física de Newton: por meio de leis universais e cálculos matemáticos, é possível descrever com exatidão o movimento dos objetos, sejam eles planetas ou maçãs.

$\mathrm{Na}$ área da saúde, este legado ajudou a construir o modelo biomédico. Tendo a física como exemplo ideal de ciência, o modelo biomédico entende o corpo humano como se fosse uma máquina, que para ser compreendida deve ser decomposta em partes - ou peças - cada vez menores. Quando, no século XIX, começaram a ser descobertas as bactérias causadoras de diversas doenças, a compreensão do processo saúde-doença ficou ainda mais estreita, pois parecia bastante e suficiente encontrar, para cada mal, o agente infeccioso correspondente, e contra ele desenvolver um medicamento.

Esse modelo de explicação do processo saúde-doença, dito unicausal, dava conta de explicar o adoecimento quando ainda era mais comum as pessoas morrerem de doenças infecciosas - varíola, tuberculose, dengue. Quando essas foram cedendo espaço para as doenças crônico-degenerativas, tais como as doenças cardiovasculares e o câncer, suas limitações ficaram evidentes: não mais apenas o "agente etiológico" deveria ser considerado, mas também o "hospedeiro" e o "ambiente". Entretanto, esses elementos continuam a ser examinados com base numa lógica reducionista, que prima pela explicação biologicista. Relações sociais, culturais, políticas e econômicas são reduzidas a fatores do ambiente físico. Assim, por exemplo, a brutal exploração e expropriação da saúde a que são submetidos os trabalhadores na indústria do

2 Quem quiser saber mais sobre o tema encontrará nos textos de Rita Barata (1990), "A historicidade do conceito de causa", e de Elizabeth Souza e Angelo de Oliveira (2000), "O processo saúde-doença: do xamã ao cosmos", excelentes suportes. 
amianto fica reduzida à existência de um agente - o asbesto - no ambiente, causando assim a asbestose.

Portanto, foi possível identificar pelo menos duas grandes correntes que procuram explicar como ocorre o processo saúde-doença: uma que o reduz a seus aspectos biológicos, e outra que o toma como determinado pelas estruturas sociais e políticas por meio das quais se relacionam os homens.

Retornando à discussão inicial, fica mais fácil entender porque promover saúde pode ter significados vários. Procure responder você mesmo: como é a promoção da saúde dentro de um e outro referencial?

O desenvolvimento do conceito de promoção da saúde esteve relacionado à percepção de que o avanço tecnológico na medicina e a oferta massificada de atos médicos não estavam produzindo necessariamente melhoria na saúde das populações. Vários estudos começaram a apontar que outros fatores - externos à área médica - pareciam produzir impactos muito mais significativos.

Foi emblemático o Relatório Lalonde, produzido em 1974, no Canadá. Nele são reconhecidas várias influências sobre a saúde das pessoas: a extensão e natureza dos serviços de saúde, a carga genética e a constituição biológica, o estilo de vida individual e a influência ambiental. Essas e outras contribuições vieram desaguar na Conferência Internacional sobre Cuidados Primários em Saúde, ocorrida em Alma-Ata, em 1978. Nessa Conferência houve forte crítica ao uso inadequado de tecnologia, propugnando-se a priorização de serviços promocionais e preventivos.

Em 1986, foi realizada a I Conferência Internacional de Promoção de Saúde, em Ottawa, no Canadá. Na Carta de Ottawa, afirmava-se:

Promoção de Saúde é o nome dado ao processo de capacitação da comunidade para atuar na melhoria da sua qualidade de vida e saúde, incluindo uma maior participação no controle deste processo. Para atingir um estado de completo bem estar físico, mental e social, os indivíduos e grupos devem saber identificar aspirações, 
satisfazer necessidades e modificar favoravelmente o meio ambiente. A saúde deve ser vista como um recurso para a vida e não como um objetivo de viver. (PROMOÇÃO, 1996, p. 11)

À Conferência de Ottawa seguiram-se outras que reafirmaram e esmiuçaram seus princípios. Cumpre observar que muito do pensamento da promoção da saúde foi gerado nos países desenvolvidos, portanto voltado para os desafios concretos que aqueles sistemas de saúde precisavam superar. Em geral, as necessidades básicas das populações já haviam sido supridas, ainda que desigualdades sociais não tivessem sido eliminadas. No interior do setor saúde, a questão não chegava a ser o aumento dos recursos investidos, mas uma maior efetividade resultante destes.

Nos países periféricos, o pensar a promoção da saúde não poderia prescindir de uma reflexão sobre a gritante iniquidade social, as relações de dependência, a falta de investimentos públicos nos setores sociais.

A Carta de Ottawa, reforçada pela Declaração de Adelaide, sugere cinco campos de ação para a promoção da saúde:

- construção de políticas públicas saudáveis;

- criação de ambientes favoráveis à saúde;

- desenvolvimento de habilidades individuais;

- reforço da ação comunitária;

- reorientação dos serviços de saúde.

Estes campos de ação serão discutidos a seguir.

\section{CONSTRUÇÃO DE POLÍTICAS PÚBLICAS SAUDÁVEIS}

Quando se parte de um referencial de saúde que comporta somente seus aspectos biológicos, as ações com vistas a alcançar a saúde são exclusivamente internas ao setor saúde. Entretanto, se há o entendimento 
de que a saúde é socialmente determinada, o espectro de ação política amplia-se sobremaneira.

Um exemplo banal, que ocorre em boa parte das cidades brasileiras: o enfrentamento das doenças de pele, extremamente comuns em áreas com precárias condições sanitárias. O enfoque biologicista tende a abordar o problema através de medicamentos que debelem, temporariamente, o problema, que volta a se recolocar de imediato. Mesmo assumindo um discurso mais avançado e adotando a retórica da "educação em saúde", a intervenção se restringe ao aconselhamento de "hábitos sadios", muitas vezes deslocados da realidade em que as pessoas vivem.

Para enfrentar esse problema, políticas públicas saudáveis envolveriam a universalização do acesso ao saneamento básico; a garantia à moradia de qualidade; a geração e distribuição de renda. Entretanto, tais políticas não seriam realizadas exclusivamente por médicos, ao contrário da prescrição de medicamentos e aconselhamento sobre higiene. Percebe-se então que a promoção da saúde é tarefa cujos atores vão muito além do que tradicionalmente se entende por "profissionais de saúde".

Começamos por um exemplo de fácil entendimento, mas outros podem ser colocados. É necessário que se pergunte: a política de transportes é uma política saudável? Seu desenho visa privilegiar um maior conforto e segurança ao transporte individual ou coletivo? Ela torna o deslocamento dos trabalhadores num momento a mais de exposição a riscos e de deterioração da saúde? Ela incentiva o emprego de transportes menos poluentes? Leva à superutilização de veículos individuais? Há alguma opção declarada pela segurança de pedestres e ciclistas, mesmo quando compromete a fluidez do tráfego?

Tudo isso pode parecer muito distante das preocupações cotidianas dos profissionais de saúde, mas irá refletir concretamente no trabalho do cirurgião buco-maxilo-facial que trabalhe num centro de traumatismo da face, por exemplo.

Outra forma de expressá-lo pode ser através da citação de um fragmento da Declaração de Adelaide (PROMOÇÃO, 1996), que afirma: 
"o principal propósito de uma política pública saudável é criar um ambiente favorável, para que as pessoas possam viver vidas saudáveis".

Ora, é preciso ter clara a não neutralidade da promoção da saúde. Compreender que setores governamentais devem ser responsabilizados pelas consequências de suas decisões sobre a saúde das pessoas implica em negar uma visão já cristalizada: a que afirma que não cabe ao Estado um papel regulador, pois este seria uma prerrogativa das forças de mercado.

Isso tem uma elevada importância quando se pondera sobre que papel os profissionais da saúde devem ter na promoção da saúde. No modelo biologicista, esse papel não era questionado, e consistia em executar atos médicos e orientar pacientes. Se em promoção da saúde outros fatores vêm se somar ao processo, o papel dos profissionais de saúde se encontra agora ampliado. Não que não possam mais realizar assistência à saúde - afinal se não a prestarem, quem os fará?

Mas além dessas atribuições, outras se colocam, Aubrey Sheiham e Samuel Moysés (2000) destacam a importância da advocacia em saúde, definindo-a como a ação dos profissionais de saúde junto a formuladores de políticas e formadores de opinião quanto a questões que causam impacto na saúde.

\section{CRIAÇÃO DE AMBIENTES FAVORÁVEIS À SAÚDE}

Uma questão relevante que se impõe cada vez mais é o impacto que as modificações no meio ambiente produzem sobre a saúde. Desta forma, a utilização responsável dos recursos naturais necessariamente deverá fazer parte da agenda da promoção da saúde. Basta lembrar como a escassez de água potável é capaz de aumentar a mortalidade infantil. Além disso, quando falamos de "ambientes saudáveis", estamos nos referindo também à organização social do trabalho, os espaços de lazer, a escola, a moradia. Devemos nos perguntar se as fábricas, os escritórios, as universidades, os hospitais são ambientes saudáveis. 
Selene Carvalho Herculano (1992) traz uma interessante discussão sobre a questão ambiental. Afinal - e você mesmo já deve ter percebido - há inúmeros discursos diferentes, por vezes contraditórios, sobre a temática do ambiente.

Existe, por exemplo, uma visão romântica, mitificada, da natureza, segundo a qual toda e qualquer intervenção humana é nefasta. Esta não é uma ideia nova: desde o século XVIII, já havia um sentimento de negação ao processo industrial e certa "glamourização" da vida campestre.

A utilização de bombas nucleares, antes da metade do século XX, no final da $2^{a}$ Guerra Mundial, vitimando não só a população civil presente, mas também as gerações que nasceram após o conflito, fez com que as pessoas se dessem conta do imenso poder destruidor que tem a espécie humana e de como a vida é frágil.

O Relatório Brundtland (COMISSÃO..., 1991, p. 46) definiu desenvolvimento sustentável como "aquele que atende às necessidades do presente sem comprometer a possibilidade de as gerações futuras atenderem a suas próprias necessidades". No entanto, o termo não está imune a variações de uso e de interpretação.

Comecemos pela palavra "desenvolvimento", que já nos é bastante familiar devido ao costume de classificar os países em "desenvolvidos", "subdesenvolvidos" e "em desenvolvimento". Reparem como essa divisão nos induz a pensar que o subdesenvolvimento nada mais é que um estágio, uma fase na vida dos países e que todos irão, dentro da ordem social vigente, tornar-se desenvolvidos, tanto quanto a humanidade tende ao progresso e à evolução.

No entanto, Celso Furtado (1996) nos alerta para o que ele denomina de "mito do desenvolvimento econômico", advertindo que a conversão de todos os países em "desenvolvidos" não só não é possível como também é insustentável. Ora, os Estados Unidos são o país que mais produz, que mais consome, e que mais polui no mundo. Se todos os seres humanos passassem a ter o mesmo estilo de vida dos norte-americanos, um desastre sem proporções ocorreria em curto espaço de tempo. Então, qual a solução? 
Alguns têm advogado em defesa do "crescimento zero", o que seria uma saída não só injusta - porque é inconcebível decretar que alguns milhões que vivem nos países periféricos a continuar vivendo em condições sub-humanas e morrendo de fome, quando se sabe que no planeta se produz mais alimentos que o necessário para nutrir a população mundial; como também derrotada, pois os países desenvolvidos não concordariam em parar seu crescimento. Basta lembrar a obstinação dos Estados Unidos em não assinar o Protocolo de Kyoto, acordo internacional que estabelece metas de redução dos gases do efeito estufa.

Daí porque a discussão ambiental está inevitavelmente atada à questão do tipo de sociedade que queremos ter. É possível não degradar o ambiente, persistindo num modelo de desenvolvimento que privilegia a exploração e exorta ao consumismo? É por isso que não nos parece correta a ideia de algumas correntes ambientalistas que veem a causa dos problemas ecológicos na pobreza e prescrevem como solução a contenção demográfica das populações marginalizadas. Entendem a miséria como causa da destruição do ambiente, mas não conseguem perceber que ambos os fatos - miséria e destruição ambiental - têm determinantes comuns: a maneira como a sociedade se estrutura. Logo, a defesa do ambiente não poderá acontecer descasada da defesa das pessoas que nele vivem.

\section{DESENVOLVENDO HABILIDADES PESSOAIS}

Sobre esse campo de ação, diz a Carta de Ottawa:

A promoção da saúde apóia o desenvolvimento pessoal e social através da informação, educação para a saúde e intensificação das habilidades vitais. Com isso, aumentam as opções disponíveis para que as populações possam exercer maior controle sobre sua própria saúde e sobre o meio-ambiente, bem como fazer opções que conduzam a uma saúde melhor. (PROMOÇÃO, 1996, p. 15-16) 
É necessário empreender uma discussão em torno do termo "Educação em Saúde"; aparentemente consensual, mas sobre o qual existem variadas concepções.

De fins do século XVIII, perpassando o século XIX e chegando às primeiras décadas do século XX, a educação sanitária foi mais uma forma de controle sobre a classe trabalhadora. Quanto a esta última, fazia-se necessário domesticá-la, moralizá-la, higienizá-la, evitando assim não só quaisquer tipos de doenças que grassavam em meio à miséria - a tuberculose, a sífilis, o alcoolismo - como também a vagabundagem, a delinquência ou, ainda pior, a rebelião. Neste sentido, Nilson do Rosário Costa (1984) realiza um interessante resgate de como a educação em saúde, ao ditar normas disciplinadoras, contribuiu para a construção de um proletariado mais funcional ao capitalismo.

No início do século $X X$, amparado em teorias pseudocientíficas de cunho racista, consolida-se o eugenismo: a "higiene da raça". Seu objetivo era impedir, sobretudo através de medidas coercitivas, a reprodução de tantos quantos pudessem levar à "degeneração da raça": grupos populacionais não brancos, pobres, homossexuais, delinquentes, doentes mentais, alcoólatras, incapazes e criminosos. Essa abordagem foi perdendo o seu apelo, sobretudo após a derrocada do fascismo e o término do regime autoritário do Estado Novo.

Gradativamente, a educação sanitária, inspirada pela crença no crescimento econômico como forma de superar o subdesenvolvimento, passou a focalizar a integração das camadas marginalizadas da população. Assim, partia-se do pressuposto de que a pobreza era causada pela ignorância e que a educação em saúde, com seus conteúdos sobre a higiene corporal, seria capaz de salvar as pessoas de si mesmas e de sua própria bestialidade.

Essas concepções, tidas por superadas, deixaram marcas profundas nas atuais práticas e teorizações da educação em saúde. Mas, essa herança se esconde por trás de novos e atraentes discursos que se apropriam de conceitos utilizados por aqueles que fazem a sua crítica. 
Predomina atualmente uma concepção de que a Educação em Saúde deva ter por objetivo a modificação de hábitos individuais de forma a permitir a adoção de atitudes mais saudáveis. Segundo o nosso entendimento, tal postura alicerça-se em uma educação chamada bancária por Paulo Freire (1997). Na educação bancária o educador realiza "depósitos" nas mentes "vazias" dos educandos.

Na visão "bancária" da educação, o "saber" é uma doação dos que se julgam sábios aos que julgam nada saber. Doação que se funda numa das manifestações instrumentais da ideologia da opressão - a absolutização da ignorância, que constitui o que chamamos de alienação da ignorância, segundo a qual esta se encontra sempre no outro.

O educador, que aliena a ignorância, se mantém em posições fixas, invariáveis. Será sempre o que sabe, enquanto os educandos sempre os que não sabem. A rigidez destas posições nega a educação e o conhecimento como processos de busca. (FREIRE, 1997, p. 58)

Contrapondo-se a esta educação, Paulo Freire (1997, p. 68) nos fala da educação problematizadora e libertadora, fundada no diálogo: "ninguém educa ninguém, ninguém educa a si mesmo, os homens se educam entre si, mediatizados pelo mundo", ou seja, a partir da realidade concreta. Exatamente pelo fato de não considerar os educandos vazios de conhecimento, mas detentores de um saber próprio, o processo educativo começa pela exploração desses conhecimentos prévios, auscultando como as pessoas percebem a realidade. Daí por que se fala na relação prática-teoria-prática: parte-se de uma primeira apreciação da realidade de modo a identificar nela os problemas que precisam ser resolvidos. Os educandos se confrontam com uma realidade que atinge o seu senso de investigação, sua curiosidade, e indagam-se sobre os porquês que a constituem. O educador, então, auxilia no processo de apreensão da teoria, não uma teoria "transferida", mas uma teoria que precisa ser apropriada pelos educandos. Ao tomarem a teoria para si, os educandos podem agora formar uma nova imagem da realidade - não mais 
aquela imagem inicial, ingênua, mas uma imagem da realidade fecundada pela teoria. O conhecimento não foi doado, foi conquistado, construído. Entretanto, a teoria que não transforma a realidade é estéril, por isso faz-se necessário voltar à prática: para transmutá-la, reconstruí-la. O saber assume um caráter libertador, dado que é uma decodificação do mundo para transformá-lo.

Do que foi discutido, percebe-se que determinadas explicações do processo saúde-doença são mais cômodas quando trabalhadas com certas concepções de educação. Assim, a visão biologicista, que toma o fenômeno da saúde em sua dimensão meramente natural, encontra na educação bancária uma forma viável de se reproduzir. Se as doenças têm explicações restritas a micro-organismos, fatores do ambiente e do hospedeiro, cumpre transmitir às pessoas as formas mais eficientes de evitá-las. Mas, como modificar essa estrutura ditando normas de comportamento, se para além dos agentes etiológicos há que se considerar a estrutura social em que vivem as pessoas? Somente com o fortalecimento da autonomia e da capacidade transformadora de mulheres e homens atinge-se o núcleo determinante do processo saúde-doença.

Uma decorrência cruel, ao tomar a concepção bancária como prática de educação em saúde, é a aposta na modificação de hábitos individuais como condição suficiente para alterar os níveis de saúde. Assim, as pessoas são levadas a pensar que são suas atitudes pessoais que ocasionarão saúde ou doença tendo a ilusão de que podem escolher.

Em promoção da saúde fala-se bastante em autocuidado, mas mesmo este conceito deve ser contextualizado. Uma coisa é trabalhar o autocuidado entre as pessoas de forma a torná-las mais donas de suas vidas, mais autônomas em relação aos profissionais de saúde.

Trabalhar o autocuidado e a autonomia não pode ser confundido, entretanto, com a completa responsabilização das pessoas com o que ocorre com sua saúde. Se compreendermos que a saúde tem determinantes sociais, não faz sentido supor que indivíduos tenham total 
controle sobre a prevenção das doenças, pois isto pode levar a um fenômeno conhecido como culpabilização da vítima.

Exemplos desse fenômeno ocorrem todos os dias nos centros de saúde. Pessoas doentes, alijadas dos seus direitos sociais, são tratadas pelos profissionais de saúde como as grandes culpadas por suas enfermidades: porque "não se cuidam", "não dão importância à doença", são "preguiçosas", "ignorantes". Muitas vezes este discurso se apresenta sob o rótulo "educação em saúde", embora contribua somente para a destruição da autoestima das pessoas.

\section{REFORÇO DA AÇÃO COMUNITÁRIA}

O trabalho comunitário tem sido apontado como uma necessidade há bastante tempo: a Conferência de Alma-Ata já enfatizava sua importância. Entretanto, há visões diversas sobre o assunto: no interior de uma determinada corrente, a ação comunitária se constitui no fomento ao trabalho das pessoas marginalizadas para que estas tomem para si a tarefa de prestar os serviços essenciais que Ihes são negados. É a lógica dos mutirões, do voluntariado, quando esses têm por objetivo a simples substituição do dever do Estado, sem empreender uma reflexão sobre a razão do não cumprimento pelo Estado de seu dever. Essa visão se coaduna com o entendimento de que não é responsabilidade do Estado a garantia dos direitos sociais a todas as pessoas.

Portanto, é preciso não confundir o apoio às ações comunitárias com a defesa do Estado mínimo. Ao contrário, estas devem ser um espaço privilegiado de exercício da cidadania. Mutirões e voluntariados podem até existir, mas não são um fim em si mesmos, são um recurso pedagógico com o qual se constrói a autoestima e o sentimento de pertencimento ao grupo. Desta maneira acumulam-se forças para a conquista de direitos, não de concessões. 


\section{REORIENTAÇÃO DOS SERVIÇOS DE SAÚDE}

Embora o texto tenha se preocupado em ressaltar a importância de determinantes externos ao setor nos níveis de saúde da população, não cabe dúvida quanto à necessidade de construir sistemas de saúde que sejam universais, justos e efetivos. Caso contrário, não mereceria tanta importância toda a luta para implantar o SUS ao longo de todos esses anos.

A orientação a ser dada aos serviços de saúde foi detalhada no capítulo "Organizando o SUS". Por ora, basta lembrar que, para trabalhar neste sistema de saúde, é necessário um novo profissional, com novas habilidades, para que seja capaz de enfrentar situações bem mais complexas que aquelas impostas pelo modelo biomédico.

E você? Como acha que deve ser a formação dos profissionais de saúde para que esses possam trabalhar na perspectiva da promoção da saúde?

Voltemos a pensar em Carnaubeira do Norte. Como promover saúde nessa cidade tomando como base os campos de ação propostos na carta de Ottawa? 
PARTE 2

atença a saude buc 
Este livro foi escrito para o público não universitário e para alunos de graduação, sejam de cursos da área da saúde, particularmente de odontologia, psicologia - as áreas originais de formação das autoras - , ou não. Este é o motivo pelo qual procuramos não "bucalizar" ou "psicologizar" demais o texto, de modo a torná-lo palatável mesmo àqueles que não têm nada a ver com o assunto.

Entretanto, em nossas trajetórias, sempre precisamos fazer a articulação entre os conceitos mais gerais da saúde coletiva e os campos de atuação em que iriam atuar nossos estudantes. Este é o motivo pelo qual apresentamos os capítulos a seguir.

\section{OS MODELOS DE ATENÇÃO À SAÚDE BUCAL CONTADOS POR DONA MARIA ${ }^{3}$}

Dona Maria tem 60 anos, é dona de casa e mora na Favela do Arco-Íris. Durante o processo de territorialização do município de Panaceia, um membro da equipe de saúde da família foi conversar com ela. O diálogo foi o seguinte:

- Porque quando a gente veio morar aqui no Arco-Íris, a gente gostou muito, porque era perto de tudo. Tinha hospital, tinha escola. E tinha o colégio estadual, que era o sonho de toda mãe poder matricular os fiIhos lá, porque era muito bom, muito puxado, os professores eram bons e davam muita assistência aos alunos. Tinha até um gabinete de dentista! O dentista atendendo os meninos do colégio, tratando, né? Obturando o dente que estava furado, arrancando quando não dava mais jeito.

- E que mais que o dentista do colégio fazia?

- Fazia isso mesmo: obturar, arrancar os dentes dos meninos. Dos adultos, não, porque era só para as crianças, só das crianças do colégio. Tinha mãe que ficava com raiva porque tinha mais de um filho e o menorzinho não estudava no colégio. Aí, não era atendido. Ou então, os mais

3 Indicamos, para aqueles que desejarem se aprofundar no tema, a leitura do livro Odontologia e saúde bucal coletiva de Paulo Capel Narvai (1994). 
velhos também não atendia. Aí, o dentista explicava que pra esses mais velhos não tinha mais jeito, tinha de cuidar enquanto era novo.

- E depois?

- Ah, depois teve um programa, né? Um programa grande, que queria tratar de todos os meninos. O meu do meio chegou a participar desse programa, porque não era só no colégio estadual, não, era em todas as escolas. Vinha como se fosse um carroção. A senhora sabe... Carroção, né? Cheio de consultório dentro. No começo, a gente não acreditava muito, não, porque nem parecia consultório de dentista. E era um mundaréu de gente, não era só doutor, não. Tinha umas mocinhas que ajudavam os doutores, ficavam atendendo junto. Num instante o tratamento acabava. O menino tinha seis, oito obturações pra fazer, não era aquela lengalenga de antes, ia no dentista duas vezes e pronto, já resolvia tudo.

- E depois?

- Depois veio aquela estória de prevenção, não é? De que não adiantava tratar nada, que tinha que prevenir. Então ensinavam a escovar, porque tinha que saber escovar pra não dar cárie. E tinha muita palestra, explicando o bichinho que dá no dente, que não pode comer doce, que tem que escovar... As crianças gostavam, porque tinha brincadeira, teatro, essas coisas...

- E a senhora gostava?

- Assim... Das palestras eu gostava, mas eu achava que tinha que tratar também. Porque quem não tem nada, tá bom ficar só limpando, cuidando. Mas, e quem tem? Quem tá com o dente doendo vai querer tratar, não vai nem querer ouvir palestra! Pelo menos, eu penso assim.

- E como a senhora acha que devia ser?

- Olhe, eu acho que tinha que prevenir, mas tinha que tratar também, né? E tinha que cuidar de todo mundo, não só de criança, ou só de velho: todo mundo tem que ter direito. Até que tem aqueles que precisam mais, que tem mais necessidade, então esses tinham que vir primeiro. Mas direito, direito mesmo, todo mundo tinha que ter. Direito de fazer tudo: botar flúor, obturar, e até fazer dentadura, se a pessoa precisar. 
- E como deveriam trabalhar?

- Eu gostava muito quando tinha as mocinhas que ajudavam que ajudavam os dentistas, porque o tratamento andava mais ligeiro. O que puder fazer para tratar mais depressa é bom, mas sem exagerar. Tem que ter tempo para o dentista escutar a gente, chamar pelo nome, saber o que a gente está sentindo... Porque a gente também é filho de Deus! E tem muito mais gente que também pode trabalhar para o povo ter dente bom.

- Como assim, dona Maria?

- A minha sobrinha, por exemplo, ela é agente de saúde. Ela visita as famílias, fala pra mãe dar o peito pra criança, vê se vacinou os filhos. Por que ela não pode também ensinar a cuidar dos dentes? E pra trabalhar assim, não precisa ficar só no posto de saúde ou na escola, como era antes, pode ser em qualquer lugar onde as pessoas possam se encontrar.

- E a senhora acha que iria funcionar?

- Acho sim. Porque os doutores têm muito o que ensinar para o povo, mas o povo também sabe muita coisa pra ensinar pros doutores.

- O que, por exemplo?

- Ah! Às vezes os doutores estudam tanto o corpo da gente, os micróbios, que às vezes esquecem que a saúde do povo também tem a ver com a vida que o povo leva. Se o salário é pouco, se no bairro não tem esgoto, se o trabalho vai matando a pessoa aos pouquinhos, como é que vai ter saúde? Tem tanta mãe que, quando o menino chora de fome, dá rapadura pro menino parar de chorar... E aí como é que o doutor, todo de branco, pode dizer para não comer doce?

- Então, o dentista não adianta de nada?

- Adianta sim, porque na hora que o dente dói só quem pode resolver é ele. Mas ele sozinho não serve pra muita coisa. Se não se juntar, se não trabalhar com os médicos e as enfermeiras do posto, com os agentes de saúde, com o povo mesmo, não vai ter resultado. Mas, se for, junto com esse povo todo, trabalhar pra todo mundo ter direito de ter saúde, de ter uma vida digna mesmo, então vai valer a pena. 


\section{MODELOS DE ATENÇÃO A SAÚDE BUCAL}

Primeiramente, é necessário esclarecer o que pretendemos expressar com as palavras "modelo de atenção à saúde bucal". Por que "saúde bucal" e não "odontologia"? Porque a noção de saúde bucal ultrapassa o conceito de odontologia, tanto quanto "saúde" e "medicina" não são sinônimos. Quando falamos odontologia, estamos nos referindo a:

1. um conjunto de conhecimentos científicos e técnicos que permite a manutenção e recuperação da saúde das estruturas orais;

2. uma profissão;

3. uma prática assistencial desenvolvida por aquela profissão, tendo por base aquele conjunto de conhecimentos.

Os cuidados com a saúde bucal já existiam mesmo antes de terem sido sistematizados tais conhecimentos técnico-científicos; e antes mesmo do surgimento da profissão. As pessoas já cuidavam dos dentes antes de existirem dentistas! Atualmente, entende-se que é necessário reunir mais elementos além daqueles fornecidos pela profissão odontológica e seu cabedal de conhecimentos para que a saúde bucal seja alcançada. Voltaremos a esta questão mais tarde. 
Quanto ao termo "atenção", concordamos com a distinção que Paulo Capel Narvai (1992) faz entre "assistência" e "atenção" à saúde. A assistência odontológica compreende aqueles procedimentos destinados a consumidores individuais, podendo tanto ser preventivos como curativos. Dessa forma, tanto a restauração que o dentista realiza, quanto a profilaxia que o técnico em higiene dental executa, ambos são exemplos de assistência odontológica, não importando o ambiente em que foram executados: consultório particular ou clínica pública.

A atenção à saúde bucal inclui a assistência odontológica, mas a ultrapassa porque incorpora as ações de alcance coletivo, que podem ser internos ou externos ao setor saúde. Ações educativas com grupos de pessoas são exemplos de atenção à saúde bucal, assim como: a fluoretação da água, o fornecimento de água tratada, a geração de empregos, etc. Observe que não é necessário que a atenção à saúde seja desenvolvida por membros da equipe odontológica.

As práticas em saúde são construídas seguindo diferentes formatações. Devemos, para entendê-las, perguntar: qual conceito de saúde está implícito nessas práticas? Em que contexto social elas se desenvolvem? Quais são os recursos humanos nelas envolvidos? Qual é o público alvo? Quais tecnologias utilizam? Em que ambiente se desenvolvem? Quais resultados pretendem alcançar? Quais são suas justificativas?

Esses elementos constituirão os modelos de atenção à saúde. É importante advertir que modelos são construções teóricas que nos permitem refletir melhor sobre a realidade, e que essa última, com suas grandes contradições, é mais rica, mais profunda que nossos modelos explicativos. Vamos, então, a eles.

\section{“ODONTOLOGIA” ARTESANAL}

O termo "odontologia" não está bem empregado aqui, pois as práticas ainda não eram embasadas nos conhecimentos oriundos do método científico moderno. Estamos nos referindo a épocas anteriores ao 
surgimento da primeira faculdade de odontologia - em 1840, nos Estados Unidos, e em 1884, no Brasil.

Considerado o pai da medicina, Hipócrates, que viveu na Grécia Antiga, no século IV a.C., explicava que as doenças aconteciam por causa do desequilíbrio entre os elementos que constituem o corpo humano: terra, ar, água e fogo; os fluidos corporais: sangue, bile amarela, bile negra e fleuma; e os estados elementares: frio, calor, secura e umidade. A medicina hipocrática dedicava especial atenção ao estudo dos sintomas para o conhecimento das doenças. A palavra "clínica" vem do grego e significa "leito", pois o estudo consistia em observar a evolução dos sintomas do paciente acamado. Durante a Idade Média, os ensinamentos hipocráticos ficaram confinados nos mosteiros, enquanto grande parte da população tinha uma visão religiosa da doença. A medicina era um ofício de religiosos; sua prática era considerada mais nobre que a dos cirurgiões e barbeiros. Muitas eram as atividades a que estes últimos se dedicavam: tratavam fraturas e ferimentos, drenavam abscessos, realizavam sangrias e aplicavam ventosas (métodos terapêuticos da época), faziam barba e cabelo e extraíam dentes. Contudo, estes não gozavam do mesmo prestígio daqueles.

Com o Renascimento, o ensino médico deixou os mosteiros e ocorreu um flagrante desenvolvimento da anatomia e da fisiologia. Foram os cirurgiões-barbeiros que mais tarde vieram a se constituir em dentistas. Como trabalhavam esses barbeiros?

Na inexistência de faculdades, o aprendizado acontecia com alguém mais experiente. Aquele que desejasse aprender o ofício deveria trabalhar como aprendiz junto a um mestre até dominar a técnica. A prática era, em geral, itinerante: o barbeiro montava sua banquinha na feira e, em meio à multidão curiosa, realizava seu atendimento. Para os dentistas constituírem uma profissão, foram necessários dois movimentos: o de instituir um ensino profissional, ordenado pelos próprios dentistas - assim surgiram as faculdades - e a proibição, pelo Estado, do exercício da prática daqueles que não fossem considerados "aptos". 
É importante esclarecer que a criação das escolas odontológicas e a proibição da prática pelos não diplomados não extinguiram o modelo de "odontologia" artesanal, apenas o tornou residual, tanto é que nos países do Terceiro Mundo, o Brasil inclusive, ainda é possível encontrar pessoas que tratam de dentes sem terem estudo profissional, geralmente atendendo populações marginalizadas.

\section{ODONTOLOGIA TRADICIONAL}

Percebe-se que a criação da primeira faculdade de odontologia em Baltimore, no século XIX, nos Estados Unidos, é o marco que assinala o surgimento de outro modelo - a odontologia tradicional, também chamada odontologia científica ou flexneriana.

Esse nome feio - flexneriana - tem sua origem em um relatório escrito por um norte-americano chamado Flexner, que, no início do século XX, propôs uma série de modificações nas escolas médicas da época. Jorge Cordón (1998) alerta que, enquanto o relatório Flexner influenciou o ensino da medicina, a odontologia teve seu correspondente no Relatório Gies. Contudo, as características fundamentais são basicamente as mesmas.

Eugênio Vilaça Mendes (1986) enumera as características desse modelo:

Mecanicismo: a medicina e a odontologia flexneriana entendem o corpo humano à semelhança de uma máquina, cujo funcionamento pode ser entendido se conhecermos as peças que a compõem. Seria possível consertar um mecanismo quebrado somente pela reposição da peça defeituosa, pois as máquinas têm comportamento extremamente previsível.

Biologicismo: a odontologia científica fundamenta-se de tal forma nas ciências biológicas que considera apenas esse nível da realidade. Desta forma, acredita ser possível agir sobre as doenças somente com os conhecimentos anatômicos, fisiológicos e bioquímicos, sem 
investigar o papel da organização da sociedade, do simbólico, da cultura na determinação das enfermidades.

Individualismo: a odontologia tradicional é individualista, tanto em relação aos recursos humanos - o dentista trabalha só; quando muito, conta com um(a) atendente - , quanto em relação ao seu objeto: o indivíduo, considerado isoladamente. Ademais, opera com base na visão de que é o próprio doente o responsável pelos seus problemas de saúde, num jogo em que a vítima se torna o culpado.

Especialização: na medicina é flagrante o alto grau de especialização da prática, fazendo com que o indivíduo seja "esquartejado" entre diversos profissionais, perdendo-se, assim, a visão do todo - salientemos, esse "todo", para nós, não se resume ao "todo" biológico. A odontologia já surge, ela própria, como uma especialidade, tomando a boca para si como objeto de trabalho e fracionando-a ainda mais em dentes, gengivas, condutos radiculares, etc.

Tecnicismo: paralelo ao avanço da especialização, ocorre uma dependência cada vez maior da técnica, de insumos e equipamentos sofisticados. A assistência de qualidade passa a se confundir com a utilização de procedimentos muitas vezes desnecessários: médicos requisitam exames sem nenhuma relevância em muitos casos, dentistas compram "o último lançamento" no congresso sem ainda saber se terá utilidade. Isso ocorre porque o modelo fexneriano alimenta uma próspera indústria de insumos que, como todas as outras, precisa eternamente criar novas necessidades.

Curativismo: partindo de uma falsa oposição entre prevenção e cura, a odontologia tradicional centra toda a sua atenção na segunda. Não é mera coincidência o fato de serem justamente as ações curativas as que permitem um mais alto grau de tecnificação e especialização, sendo as de maior custo.

Mercantilismo: a odontologia tradicional fundamenta-se no mercado, na venda de serviços, no que não difere do modelo anterior. Contudo, a parcela da população capaz de comprar estas mercadorias é minoritária. 
Dizemos que o modelo da odontologia flexneriana é hegemônico por se tratar do formato predominante, tanto nas práticas odontológicas, quanto nos "corações e mentes" dos cirurgiões-dentistas. Entretanto, esse modelo tem sofrido uma série de críticas, a ponto de, no documento da VII Conferência Nacional de Saúde, em 1980, ter sido apontado como portador de diversas distorções; dentre as quais, a ineficiência, por ser de alto custo e baixo rendimento, e a ineficácia, uma vez que não resolvia os problemas de saúde bucal da população.

Enquanto a odontologia científica se desenvolveu no setor privado, as tentativas de superá-la deram-se no interior do Estado. A princípio, num conceito estrito de Estado e, depois, num conceito ampliado, que inclui também a sociedade civil.

\section{ODONTOLOGIA SANITÁRIA/SOCIAL}

Alerta-nos Zanetti (1996) de que as primeiras formas de inserção da odontologia na esfera pública não iam além da mera reprodução da prática flexneriana, transposta para os serviços de saúde. Contudo, foi se tornando cada vez mais claro que, para o enfrentamento dos problemas de saúde bucal numa perspectiva populacional, a lógica da assistência individual não seria suficiente. Assim, a primeira tentativa consistente da odontologia de se aproximar da saúde pública foi através da odontologia sanitária, surgida nos anos 1950, que elegeu como público alvo o escolar. Entretanto, ao construir toda a sua sistemática de atuação no interior da escola, acabou por se distanciar dos demais profissionais de saúde.

Os conhecimentos disponíveis na época levavam a acreditar que a cárie era um processo que, uma vez iniciado, não mais poderia ser controlado. Isso se traduzia no conceito de "geração perdida", ou seja, nada poderia ser feito em relação às pessoas já acometidas pela cárie, restando somente procurar atuar junto àquelas livres da doença.

A odontologia sanitária adotou o sistema incremental como forma de organizar o atendimento. Exemplificando: o dentista lotado em uma 
determinada escola, após fazer um levantamento epidemiológico, atenderia todas as crianças do primeiro ano, efetuando todos os procedimentos restauradores de que precisassem. Feito isso, estas crianças passavam a "acumular doenças", passando ao ciclo de manutenção, enquanto todas as crianças do segundo ano receberiam atendimento. E assim, sucessivamente, até retornar às crianças do primeiro ano, que então teriam novas necessidades.

O principal problema era a grande quantidade de necessidades de tratamento do primeiro grupo. Essas eram tantas que findava o ano letivo sem se conseguir nem mesmo completar o tratamento de seus componentes. Quando o novo ano começava, novas crianças entravam no primeiro ano, com mais dentes a serem restaurados. Nesse modelo, prevenção e cura se encontravam desarticulados. Nas cidades onde havia fluoretação da água, esse era o único método preventivo utilizado; onde esta inexistia, realizavam-se programas de aplicação de bochechos fluorados durante o ciclo de manutenção. Estranha lógica essa, em que a prevenção vem depois da cura!

Ainda não existia o conceito de equipe de saúde bucal; o cirurgiãodentista trabalhava isolado em seu gabinete, no interior da escola. A auxiliar desempenhava funções menores e se incumbia da aplicação de bochechos fluorados.

Esse modelo chegou ao Brasil como mais uma prova da forte influência dos Estados Unidos sobre o nosso país, via Fundação de Serviços Especiais de Saúde Pública (SESP). A Fundação SESP foi a instituição que difundiu diversas tecnologias em saúde bucal no Brasil: a fluoretação da água, os bochechos fluorados, o sistema incremental, os levantamentos epidemiológicos.

Entretanto, o Brasil e os Estados Unidos viviam contextos bem diferentes: enquanto nos Estados Unidos esse modelo vinha no bojo de uma série de medidas de combate aos bolsões de pobreza; no Brasil, não havia propriamente "bolsões", mas uma sociedade imersa no subdesenvolvimento que, embora começasse a se industrializar, não caminhava para 
a justiça social. Num cenário com níveis elevados de crianças fora da escola, o impacto desse modelo não chegava a ser muito evidente, como lembra Zanetti (1993, p. 118):

A desvinculação e a falta de relevância pública pode ser percebida na grande maioria dos programas de saúde bucal, nos quais não se atinge a toda a população, e sim, só a população infantil; não se atinge toda a população infantil, e sim, só aquela de 7 a 12 anos; não se atinge toda a população de 7 a 12 anos, e sim, só aquela escolarizada; não se atinge toda a escolarizada, e sim só aquela escolarizada na rede pública de ensino; não se atinge todos os escolares da rede pública de ensino, e sim só aqueles da zona urbana.

É necessário salientar que muitas das limitações apresentadas por esse modelo devem ser consideradas como frutos das condições históricas e do conhecimento científico da época em que floresceu. Assim, frente à odontologia tradicional, que não incorporava nenhuma contribuição da epidemiologia e do planejamento em saúde, o sistema incremental representou um inegável avanço. Durante muito tempo, programas de saúde bucal foram confundidos com programas destinados a escolares, pois era difícil conceber uma outra forma de intervenção em saúde pública sem ousar colocar o pé para fora da escola.

\section{UM PARÊNTESE PARA FALAR DA ODONTOLOGIA PREVENTIVA E O PREVENTIVISMO}

Percebe-se, nos modelos referidos, uma dicotomia entre cura e prevenção, tomadas como opostas entre si e com total vantagem à primeira. Paulo Capel Narvai (1994) nos lembra que, nos anos 1960, a prevenção era vista como algo exótico, romântico, ou uma conspiração comunista. A prática no setor privado privilegiava os procedimentos restauradores, e a odontologia sanitária não foi capaz de romper com esta lógica, 
destinando à prevenção um papel secundário. O debate sobre "a importância da prevenção" ficava circunscrito à academia.

Só bem mais tarde, nos anos 1980 e 1990, as ações preventivas ganharam algum prestígio, em função da influência dos países escandinavos, que utilizaram um arsenal de tecnologias preventivas - dentifrícios fluoretados, flúor-gel, selantes, entre outros - que, junto à melhoria na qualidade de vida da população, foi capaz de reduzir os níveis de cárie.

No entanto, diversas vezes, a importação dessas tecnologias ocorreu de forma acrítica. No setor privado, ficou patente que a prevenção somente passou a ser considerada relevante quando pôde ser transformada em mercadoria. No setor público, diversas vezes esse instrumental preventivo foi empregado sem que se considerasse o contexto social no qual as "fórmulas mágicas" eram aplicadas. Mais grave ainda foi a assunção de que somente a prevenção seria importante, em nome da qual serviços assistenciais chegaram a ser desestruturados. A esse abuso, Jorge Cordón e Volnei Garrafa (1991) chamaram preventivismo.

\section{ODONTOLOGIA SIMPLIFICADA}

As críticas ao modelo flexneriano ensejaram o surgimento da odontologia simplificada, nos anos 1970. Seus teóricos alegavam que a prática odontológica hegemônica era incapaz de prover acesso a toda a população, por utilizar equipamentos extremamente sofisticados e empregar os recursos humanos de forma irracional.

Em consequência, a odontologia simplificada desenvolveu equipamentos, materiais e rotinas que buscavam, através da padronização e da eliminação do supérfluo, reduzir os custos da assistência para, assim, aumentar a cobertura dos serviços. Foi também a responsável pelo conceito de equipe odontológica, com ampla utilização de pessoal auxiliar e delegação de ações diretas. O ambiente clínico deixou de ser o gabinete onde o cirurgião-dentista trabalhava isolado e passou a ser a clínica modular, na qual o espaço era racionalmente planejado para permitir o 
bom funcionamento da equipe, sem desperdício de tempo e com melhor aproveitamento dos equipamentos.

Contudo, por mais que a odontologia simplificada procurasse dar maior racionalidade à prestação da assistência odontológica, não foi capaz de superar o problema do público-alvo, que continuava sendo majoritariamente o escolar, e a primazia da assistência curativa.

Mais: deturpada em seus princípios, acabou por se transformar em uma "odontologia de segunda classe para cidadãos de segunda classe", tamanho foi o exagero de simplificação que se atingiu. Contribuiu ainda para o fortalecimento do dilema quantidade versus qualidade, como se todo trabalho de alta produtividade fosse necessariamente ruim.

Porém, há que se reconhecer que a questão dos recursos humanos nunca mais foi a mesma após a odontologia simplificada, que tão bem enfatizou a importância de desmonopolizar o saber, antes latifúndio dos profissionais de nível superior. A questão da adequação da tecnologia também permaneceu, não sendo mais admissível entender que qualidade é sinônimo de sofisticação.

\section{ODONTOLOGIA INTEGRAL}

Nos anos 1980, começou-se a falar em odontologia integral, a qual procura superar dialeticamente a odontologia simplificada. É preciso citar Eugênio Vilaça Mendes (1986), que identificou três pilares da odontologia integral: a atitude preventiva, a simplificação e a desmonopolização do saber. Sobre o primeiro devemos esclarecer que este modelo finalmente conseguiu romper com a dicotomia prevenção-cura, assumindo a importância da integralidade da atenção. Em relação à segunda, salienta-se que a simplificação foi retomada na perspectiva da tecnologia apropriada, sem incidir nos exageros do modelo anterior. No que tange ao terceiro pilar, já esboçado na odontologia simplificada, percebe-se uma preocupação com a educação e a participação comunitária. 


\section{SAÚDE BUCAL COLETIVA}

Os anos 1970 e 1980 foram marcados pelo movimento da Reforma Sanitária que, no bojo do movimento pela redemocratização do país, reivindicava a saúde como um direito de qualquer cidadão a ser garantido pelo Estado. Princípios como os da universalidade, equidade, integralidade, descentralização e participação social foram defendidos durante a Oitava Conferência Nacional de Saúde, em 1986, e passaram a fazer parte da Constituição Federal (BRASIL, 1988) e da Lei Orgânica da Saúde. (BRASIL, 1990a) Poderíamos afirmar, junto com Carlo Zanetti (1996), que a saúde bucal coletiva foi o modelo que procurou concretizar esses princípios.

Antes, no entanto, é necessário explicar o que vem a ser saúde coletiva, expressão em que inserimos um "bucal". Jairnilson Paim e Naomar de Almeida Filho (1998) falam da saúde coletiva como um campo científico de caráter interdisciplinar que estuda a saúde das populações, entendendo-a como um processo social. Este último seria melhor percebido quando compreendemos a estrutura da sociedade e seus aspectos econômicos, políticos e ideológicos.

Dessa forma, assim como Mário Chaves (1986) defende que o conceito de saúde bucal só poderia ser entendido como uma abstração útil, uma vez que uma pessoa não pode ter saúde bucal e não gozar de boa saúde, o termo "saúde bucal coletiva" também só pode ser compreendido considerando-se a própria saúde coletiva nesta perspectiva.

Carlos Botazzo (1991) elencou três conceitos fundamentais para entender a saúde bucal coletiva:

1. a politização dos agentes etiológicos, que implica em entender que o processo saúde-doença tem determinantes socioculturais que extrapolam o plano meramente biológico;

2. a inculação ao campo das práticas coletivas em saúde, que significa romper com o isolamento do cirurgião-dentista, fechado em gabinetes dentro de escolas, ou consultórios 
outros, desacostumado com a interação com outros trabalhadores da saúde;

3. as ações de natureza coletiva, ou seja, ações cujo sentido seja permanentemente construído pela participação das pessoas como sujeitos do processo, deixando de lado a passividade, isto é, o acatar docilmente as recomendações do profissional todo poderoso. Isso implicaria num trabalho em grupo, aprendendo e ensinando, tomando para si e para o coletivo a necessária luta para que o direito à saúde não fique restrito a uma lei empoeirada. 


\section{HISTÓRIA - PARA FAZER PENSAR}

\section{PEDRAS MAGNAS}

A localidade onde hoje se situa a cidade de Pedras Magnas era habitada por índios de duas tribos distintas. Há pouco mais de dois séculos, os índios foram perdendo espaço para os criadores de gado, até serem expulsos completamente pelos colonizadores. Um século depois, Pedras Magnas recebeu o status de vila e seu comércio passou a circular em torno da produção de algodão. Recentemente, o lucro recebido com o algodão passou a ser investido na indústria e no comércio locais, com consequente transformação da vila em cidade.

Hoje, Pedras Magnas possui 80 mil habitantes. Como toda cidade pequena, as relações entre seus habitantes ainda são muito próximas: até pouco tempo, as pessoas se reuniam nas casas ou no clube para ouvirem os cantadores. As vizinhas ainda se sentam nas calçadas para conversar quando passa o vento à noitinha e todo mundo sabe o nome dos políticos, dos comerciantes e do padre da cidade.

Há também os loucos conhecidos. O Carro Velho, que recebeu esse apelido porque acha que é um carro. Às vezes, ele dá prego no meio da rua e, só sai do lugar se alguém chega para trocar o pneu ou colocar gasolina. A Bernadete, que, literalmente, é louca de jogar pedra. Certa vez, foi para frente do restaurante da cidade e se pôs a gritar e jogar pedras nos clientes.

E há os loucos desconhecidos; frequentemente as agentes comunitárias de saúde, ao fazer visitas domiciliares, descobrem que pessoas tidas como loucas são mantidas em cárcere pela própria família. Essas pessoas não recebem tratamento médico algum e nesta situação permanecem indefinidamente. Não chegam a saber das conversas da calçada, do último candidato eleito para vereador ou do nome do dono da padaria. Assim como os loucos conhecidos, não trabalham no comércio local, nas indústrias ou em outros espaços da cidade. 


\section{LOUCURA}

\section{AS SOCIEDADES E AS LOUCURAS}

Palavras como loucura, insanidade, psiquismo, doença mental, tão presentes no nosso cotidiano, apresentam origens históricas diversas. Desde a Grécia Antiga, já se falava de loucura. Nos textos trágicos, ela se relacionava com uma impossibilidade de escolha diante dos conflitos impostos pelo destino. Nas obras do poeta Eurípedes (480 a.C. - 406 a.C.), a loucura se psicologizou e, já nesta época, os homens estudavam a relação entre as emoções vividas e o surgimento da loucura. (CECCARELLI, 2005) Em Homero, a palavra "psyché" surgiu com alguma organização conceitual e se aproximava de uma dimensão pessoal, enquanto Platão situou a insanidade próxima a um descontrole da razão. Podemos dizer que, para estes gregos, o fenômeno conhecido como loucura se relacionava com a vida pessoal, suas emoções e a capacidade de controle e de decisão sobre ela.

Veremos que cada época e cada lugar lidaram com o fenômeno da loucura de forma diferente, além de produzir sua própria teoria sobre seu surgimento, suas características e seu possível desfecho. Na Grécia Antiga, estes loucos viviam em sociedade. Na Idade Média europeia, por sua vez, existiam loucos considerados curáveis e incuráveis. Os curáveis iam para os hospitais, em leitos reservados que se assemelhavam a 
jaulas, enquanto que os outros tipos de loucos continuavam circulando livremente. (FOUCAULT, 1975) No Renascimento, houve, pelos intelectuais, um grande retorno à leitura dos clássicos, e este período foi muito receptivo à experiência da loucura, com festas e danças de loucos por toda Europa. Ao mesmo tempo, foram, pontualmente, criados espaços de tratamento para a loucura, influenciados pela medicina árabe.

Foi somente a partir de meados do século XVII que a loucura passou a ser excluída do convívio social. Em toda a Europa foram criados espaços para internação não só dos loucos: mas de todos aqueles que eram julgados indesejáveis. Esses lugares não se dedicavam a tratar. As heranças deste modo de lidar com a loucura se encontram até os dias atuais, não só na Europa, mas em todos os lugares em que a segregação vence a nossa capacidade de lidar com a diferença.

No século XVIII, várias denúncias foram feitas sobre estes locais, por suas internações arbitrárias e formas de assistência. A partir daí se iniciaram várias teorizações e práticas a respeito da loucura.

O marco de criação da psiquiatria foi o lançamento do Tratado médico-filosófico sobre a alienação mental ou Traité, por Philippe Pinel, no ano de 1801. Em sua obra, houve momentos em que ele defendeu que as origens da loucura estavam na hereditariedade e, em outros, na "imoralidade". Por isto, criou a teoria moral sobre a alienação. Neste sentido dado à palavra imoralidade, a loucura estava ligada aos excessos e desvios. Portanto, a forma de tratá-la se dava principalmente pela mudança de hábitos e costumes. Olhando a partir da nossa realidade atual, o tratamento proposto por Pinel era extremamente violento. O médico deveria ter a autoridade sobre o louco, ou, usando a mesma palavra que Pinel usou: o médico deveria "domá-lo". Isto se dava pelo amedrontamento do alienado, por meio, entre outras coisas, da força física e de sustos.

Duas ideias que remontam ao tratamento moral têm consequências até os dias de hoje na forma com que as pessoas compreendem a loucura. A primeira delas é que a distração poderia destruir a loucura. Por isso, a importância do alienado trabalhar. A segunda é que 
o ambiente de origem do louco poderia estar na causa da alienação. Portanto, os alienados considerados curáveis deveriam ser internados em asilos, para se afastarem do meio que gerou seu adoecimento. No caso dos incuráveis, eles deveriam se afastar das outras pessoas para não contaminá-las. Esta foi a justificativa para o crescimento que se seguiu de construções asilos de caráter autoritário e segregador. Neste caso, foram respaldados por uma moral médica.

\section{O TRATAMENTO DESTINADO À LOUCURA NO BRASIL}

A história da loucura no Brasil assemelhou-se em muitos pontos à europeia. Isto é esperado, dada a sua colonização. Assim, no início do Brasil Colônia, os loucos não eram vistos como doentes. O destino que teriam variava de acordo com sua classe social e o risco que ofereciam à sociedade. Os ricos e tranquilos permaneciam em sua casa ou eram enviados para a Europa. Os ricos agitados eram colocados em um cômodo à parte, soltos ou amarrados. Já os pobres e tranquilos circulavam livremente pelas ruas, sujeitos às brincadeiras da criançada e sem qualquer forma especial de assistência.

Acompanhando as últimas tendências europeias, a partir do século XVIII, no Brasil, a loucura também passou a ser tratada como doença. Inicialmente, seu lugar de tratamento foram as Santas Casas de Misericórdia - as mesmas que se destinavam às demais formas de adoecimento. Elas destinavam espaços que passaram a ser conhecidos como "casinhas de doudos". Como várias vezes se repetiu na história da loucura, este espaço de segregação logo se tornou foco de maus tratos aos internos, tratados de forma desumana e sem as mínimas condições de higiene. Logo, o povo passou a reagir contra esta forma de violência e iniciou manifestações públicas que se repetiram ao longo dos anos.

Com base nestas reivindicações, foi iniciada, em 1841, a construção do Hospício de Pedro II, que ficou pronto somente 11 anos depois. Seus idealizadores tinham as melhores das intenções: criar um lugar de 
atendimento especializado, laico, a partir das últimas discussões científicas europeias. Naquela época, usava-se da eletroterapia, técnica que permanece no ideário da loucura; além da hidroterapia e as oficinas de trabalho e de artes. Este hospício inaugurou a "era de ouro dos asilos" no Brasil, que começaram a se espalhar por grande parte do seu território.

$\mathrm{Na}$ Europa, os hospícios começaram a ser criticados devido ao seu caráter fechado e autoritário. (QUEIROZ, 2001) Uma das primeiras tentativas de reforma deste espaço foram as Colônias Agrícolas. Elas buscavam simular uma vida em uma comunidade rural. Acontece que os loucos continuavam segregados, embora este novo lugar buscasse se afastar do aspecto de um asilo.

A enorme demanda por vagas em hospícios no Brasil e o alto custo de manutenção dos internos gerou uma crise neste modelo de tratamento. Mais uma vez, o Brasil seguiu a tendência europeia e foram iniciadas as construções de diversas colônias agrícolas, anexas aos hospícios ou independentes. Nestes lugares, o principal tratamento era a praxiterapia, tentativa de cura por via do trabalho.

No século seguinte, destacados psiquiatras, como o médico paulista Franco da Rocha, passaram a defender que o ritmo frenético das cidades levava à loucura, justificando o modelo das colônias agrícolas. Além disso, Franco da Rocha acreditava que os alienados deveriam ser isolados em lugares "moralmente higiênicos" e acompanhados por médicos. Com base em um discurso pseudocientífico, reafirmou-se a necessidade de segregação dos loucos e a centralidade do poder do médico no tratamento dos mesmos. Os hospícios e colônias agrícolas foram os principais modelos de serviços destinados aos alienados nas décadas seguintes.

A partir da década de 1950, iniciou-se, primeiro de forma tímida, o movimento de criação de serviços privados na saúde mental. Nas décadas seguintes, repetiu-se o que vimos para o sistema de saúde como um todo: o evoluir dos serviços privados em detrimento dos públicos; o tratamento em detrimento da promoção e da prevenção em saúde mental; os altos repasses financeiros para os donos dos hospícios. 
Agregavam-se à discussão as questões próprias do público específico: frequentemente, ele não era ouvido, por ser julgado desprovido de razão; os hospícios continuavam se mantendo como lugares de maus tratos; não havia o objetivo de um retorno deste público ao convívio comunitário. Em 1952, foi criado o primeiro neuroléptico, remédio usado para atenuar os sintomas de delírio e alucinação. Este fato causou a chamada "Revolução Psicofarmacológica". Ao invés da loucura ser entendida como um conflito pessoal, como na Grécia Antiga, ou ligada a questões

ambientais, como defendia Franco da Rocha, reduziu-se este fenômeno a sua dimensão biológica.

Que semelhanças existem entre os tratamentos dados aos loucos hoje, na cidade de Pedras Magnas, e aqueles que ocorreram na história da Europa ou do Brasil?

Você acha que o tratamento destinado aos loucos ainda varia de acordo com a sua classe social?

Você conhece hospícios e Colônias Agrícolas que ainda estejam em funcionamento?

Imagine que um dono de hospital recebe muito dinheiro público para manter pessoas internadas. Será que os critérios de alta utilizados serão unicamente relativos à saúde? 


\section{HISTÓRIA - PARA FAZER PENSAR}

\section{CONJUNTO IRACEMA}

Conjunto Iracema é um bairro que fica em uma cidade urbanizada, de 2 milhões de habitantes, a 10 quilômetros do centro. Não é dos piores, mas está longe de apresentar o padrão de vida da área nobre da cidade.

O índice de escolarização é baixo e o único equipamento de saúde do bairro é a unidade básica de saúde. As doenças recorrentes parecem se ligar diretamente às condições de vida da população: doenças infectocontagiosas, respiratórias, hipertensão. O esgoto corre a céu aberto, há muita criminalidade e violência no local. Os jovens não possuem espaço de lazer. A diretora da unidade básica de saúde diz ainda que chegam muitas "doenças emocionais", mas que a equipe não sabe como agir, já que não há nenhuma doença "de verdade". Nesses casos, o médico costuma passar calmante para aqueles pacientes que estão "muito nervosos".

Um dia passou uma equipe da universidade para fazer uma pesquisa sobre doenças mentais. Eles saíram dizendo que metade da população do Conjunto Iracema tinha doenças mentais, principalmente ansiedade e depressão. Disseram também que um quarto era dependente químico, inclusive de benzodiazepínicos. Essa pesquisa foi apresentada na associação do bairro e os moradores da comunidade ficaram irados: "Que direito tem esses doutores de vir aqui no nosso bairro, dizer que nós somos doidos e drogados?", perguntou o seu Joaquim no meio da apresentação. Dona Gerismar foi uma que ficou injuriada quando viu que aparecia no meio dos "drogados", só porque usa o remédio que o médico do posto passou! No caso dela, as coisas que ela sentia pareciam com aquilo que apresentaram como depressão. Ela saiu da reunião ainda mais triste: "Era só o que me faltava".

Chegando a casa, Dona Gerismar olhou ao seu redor. José, seu filho de quinze anos, tentava colocar o mais velho, paralítico, na cama. Ele 
era seu braço direito na lida diária, desde que Maurício, o pai de seu filho mais novo, saiu de casa. Carlos não se encontrava, provavelmente tinha saído para farrear e se envolveu, de novo, com aquela turma da pesada da comunidade Padre Guerra! Olhando Gabriel, o bebezinho, Dona Gerismar se punha a chorar: como comprar aqueles remédios que o médico do posto passou, se há tanto tempo ela não conseguia uma diária de lavadeira? Tomada pela tristeza e pela desesperança, ela voltou para o quarto, de onde pouco saía. Pensava: "Que raio será essa tal de depressão?". 


\section{LOUCURAE DOENÇA MENTAL}

Vimos, no capítulo passado, que o fenômeno da loucura atravessa as épocas e, em cada uma delas, é entendido e tratado de forma diversa. Talvez, o entendimento de que existe a loucura venha de um estranhamento frente a uma manifestação da existência diferente da usual - e percebemos como nossa sociedade tem dificuldades de lidar com a diferença.

Mas pensemos na Dona Gerismar. Será que ela é doente? Tristeza é doença? Tristeza se cura com remédio? Será que ela é doente porque nasceu assim ou há muitas coisas que acontecem no Conjunto Iracema que fazem com que as pessoas adoeçam, inclusive dessas "doenças emocionais" que a diretora da unidade básica de saúde falou?

Para compreendermos o tratamento destinado à loucura no Brasil atual, é preciso apresentar a perspectiva de um campo da saúde chamado "saúde mental". O fenômeno da loucura se situaria neste campo. O que é importante destacar é que, aí, não estão as doenças que não são "de verdade", como se disse no Conjunto Iracema. O que muda é a própria concepção de saúde e de doença.

Primeiramente, saúde e doença não são polos opostos. Tanto uma como outra fazem parte da vida e formam um mesmo processo, que 
se apresenta de muitas formas. Tanto num exame de laboratório quanto na desesperança. É verdade que há doenças que se podem verificar simplesmente olhando para uma pessoa, pois o seu caráter físico predomina, assim como é verdade que não há um exame de laboratório que meça a desesperança. Mas todas as doenças se manifestam em um corpo biológico e se expressam em uma dimensão psicossocial. A questão é que, por vezes, predomina a dimensão biológica e por vezes predomina a psicossocial. Quando alguém está doente, ele se vê e é visto pela sociedade de formas que mudam historicamente. Na Idade Média, uma pessoa doente poderia ser vista como alguém possuído pelo demônio ou como um santo, dependendo de como sua doença se manifestasse. (SAMPAIO, 1998) Imagine que efeitos isso produzia no doente!

Manifestações, sinais, sintomas. A palavra "doença" agrega fenômenos tão diferentes quanto gripe, câncer ou esquizofrenia. Existem doenças que sempre existiram e que os paleontólogos descobrem seus vestígios quando fazem escavações, e existem doenças que são muito próprias de um contexto específico. (BERLINGUER, 1988) No caso do Conjunto Iracema: doenças infectocontagiosas, respiratórias, hipertensão, ansiedade, depressão, dependência química. Você consegue ver como essas doenças se articulam com a vida daqueles moradores?

Vamos supor que o médico da unidade básica de saúde fosse visitar Dona Gerismar, por conta de sua "depressão", e constatasse as dificuldades do seu dia a dia. Vamos supor também que, neste momento, ele pedisse ajuda ao restante da equipe e que, juntos, tentassem incluí-la em programas de geração de renda e de assistência social, fazendo contato com outros equipamentos públicos da cidade. Neste caso, diríamos que a doença de Dona Gerismar foi um "sinal" que apontou para o fato de que havia muitas outras coisas ruins acontecendo com ela. Ela manifestou no corpo uma doença que se ligava a outras questões materiais. Nesse caso, o sinal foi muito bem vindo, uma vez que serviu para que outras coisas ruins fossem mudadas. 
É difícil acreditar, mas uma doença não é só algo negativo. Às vezes, é preciso que a gente adoeça para melhorar a forma de se cuidar, de ser no mundo, para que a gente reivindique condições de vida saudáveis.

Isso é mais interessante ainda no caso da saúde mental. Procure ler a biografia de um grande gênio da humanidade. Muitas vezes, pessoas brilhantes apresentam traços muito próximos daqueles que os loucos apresentam.

Portanto, na nossa concepção de saúde mental, entendemos que a realidade é objetiva e subjetiva ao mesmo tempo. O ser humano precisa ser visto de forma integral, nas dimensões histórica, social, política, biológica e psíquica. O que é predominantemente mental se articula com o biológico e a materialidade da existência. Portanto, não é possível atacar uma frente e deixar as outras descobertas. Assim como no debate sobre a saúde como um todo, não é possível apenas tratar a doença mental, sem que haja prevenção e promoção de saúde mental. Um sinal ou um sintoma de adoecimento devem ser tomados como denúncia de uma situação complexa. O que é diferente não é necessariamente mal, e, muitas vezes, as formas com que a humanidade lidou com loucos ou doentes mentais estavam vinculadas aos seus próprios preconceitos. A partir deste entendimento e junto com as discussões mais amplas do campo da saúde, recentemente o Brasil iniciou a criação de novos serviços de atenção aos doentes mentais. Atenção - e não somente tratamento.

Dona Gerismar e seu filho paralítico podem ser chamados de doentes? O que eles têm em comum e o que eles têm de diferente? A "depressão" de Dona Gerismar se cura com remédio? O que será que fez com que ela ficasse desse jeito? Será que o pessoal da unidade básica de saúde tem como ajudá-la? 


\section{HISTÓRIA - PARA FAZER PENSAR}

\section{AQUIPIORA}

Aquipiora é uma cidadezinha de 70 mil habitantes, localizada no Nordeste do Brasil. Sua densidade populacional é baixa e a maior parte da população mora na zona rural, praticando agricultura de subsistência. Devido às dificuldades de acesso ao centro da cidade, essas pessoas são as mais desassistidas nas ações de educação, saúde e assistência social. Além da renda oriunda da agricultura, frequentemente prejudicada pela ausência de chuvas, os moradores de Aquipiora conseguem recursos através de programas de assistência social do governo federal, de empregos junto à prefeitura municipal e de um comércio reduzido. Muitas das crianças não possuem nenhum acesso à educação ou possuem um acesso deficiente. Para estudarem, várias são enviadas muito cedo para as "casas de família", onde trabalham como empregadas domésticas em troca da oportunidade de frequentar as escolas no centro.

Aquipiora possui um Centro de Referência em Assistência Social (CRAS), que é uma unidade da Política Nacional de Assistência Social, cuja principal atuação, segundo o Ministério do Desenvolvimento Social e Combate à Fome, é proteger e atender as famílias em situação de vulnerabilidade social. Mas o CRAS é mantido com apenas uma servidora de nível superior trabalhando, bem menos do que o necessário para realizar suas atividades. Essa servidora é a Clarinha, que lá foi trabalhar por indicação política, assim como os dois profissionais de nível médio. Como eles sabem que não perderão os empregos enquanto a gestão durar, não se preocupam em realizar as atividades do programa. Na verdade, pouco aparecem lá. Sem pessoas responsáveis e capacitadas para desenvolver atividades mais complexas, este CRAS apenas oferece cursos profissionalizantes para as famílias cobertas. 
Longe dali, a cidade tem um Centro de Atenção Psicossocial (CAPS), que é um dispositivo de atenção à saúde mental. Na sua equipe, constam um psiquiatra, uma médica generalista, uma assistente social, uma psicóloga, uma terapeuta ocupacional, uma técnica administrativa, uma enfermeira, um auxiliar de enfermagem e duas profissionais que realizam serviços gerais.

Embora o CRAS seja a porta de entrada no Sistema Único de Assistência Social (SUAS) e muitos dos pacientes do CAPS necessitem da assistência social e, da mesma maneira, muitos usuários do CRAS apresentem queixas de transtornos mentais, não há previstas reuniões ou planos de atuação conjunta destas duas equipes.

No CAPS de Aquipiora registra-se um número alto de pacientes diagnosticados com síndrome do pânico. Eles têm a opção de ser tratados pela psicóloga e receber a medicação do psiquiatra, mas quando são ouvidos, apresentam uma história muito parecida.

Na literatura internacional sobre síndrome do pânico, os pacientes costumam falar de separações prolongadas que sofreram dos seus cuidadores durante a infância. Em Aquipiora, os pacientes tinham os mesmos sintomas e faziam os mesmos relatos de separação precoce. O que a psicóloga percebeu, no entanto, é que essa separação acontecia porque as crianças, especialmente as meninas, saíam da casa dos pais na zona rural e iam trabalhar na sede do município para poderem estudar, afastando-se bruscamente da própria família e sendo tratadas, a partir de então, como adultas. 


\section{ATENÇÃO PSICOSSOCIAL}

Na década de 1960, discutia-se nas academias brasileiras o modelo de medicina comunitária. Suas diretrizes de promoção de saúde; prevenção de doenças e agravos; de autocuidado, em detrimento da medicalização e do papel central do médico formaram as bases do ideário que resultou no SUS. Todas estas questões foram levadas para o campo da saúde mental.

Enquanto se falava sobre a necessária atenção integral em saúde, para a saúde mental seria necessária uma integralidade ainda maior, pois as pessoas em sofrimento mental, muitas vezes, não estavam mais integradas à sua família, à sua comunidade e à sociedade como um todo. Estavam em instituições mortificadoras, que agravavam a condição do interno ou criavam novos quadros de adoecimento. Além da dimensão biomédica, relacionam-se à saúde/doença mental a distribuição desigual de poder, de renda, as relações de trabalho, as condições materiais de existência, a violência, o preconceito, a falta de solidariedade humana, os sentimentos e significados das vivências cotidianas, a existência de redes sociais de apoio. Um campo de estudo tão vasto necessitaria de uma equipe de múltiplas formações e competências, o que também caracteriza uma ação integral.

Na década seguinte, uma equipe do INPS foi convidada a estudar e formular as bases da assistência psiquiátrica no país. O resultado deste estudo foi um manual de serviço para a assistência psiquiátrica, de forte teor comunitário, assim como a criação do Plano Integrado de Saúde Mental (PISAM), em 1977. A partir daí iniciou-se uma grande luta entre o Ministério da Saúde e os proprietários dos lucrativos hospitais psiquiátricos, que questionavam a viabilidade e a eficácia dos serviços extra-hospitalares.

A efervescente década de oitenta abrigou a I Conferência Nacional de Saúde Mental (CNSM), em 1987. É interessante apontar a distância entre a I Conferência Nacional de Saúde e a I Conferência Nacional de Saúde Mental mais de quatro décadas. Que jogo de forças, que 
interesses estariam por detrás disto? Que lugar tinha o louco, nesta sociedade, cujo código civil permitia interditar e declarar incapaz? Qual a possibilidade de diálogo e denúncia de uma pessoa excluída do convívio social, calada pela própria legislação? Esta conferência foi o momento de tratar diretamente desse e de outros temas. Portanto, uma de suas principais bandeiras foi o direito à liberdade. As instituições fechadas, ou instituições totais - manicômios, presídios, centros de internações para adolescentes infratores e fazendas terapêuticas, dentre tantas outras - , representam a nossa dificuldade em lidar com as diferenças. Neste momento, propôs-se fazer a chamada "reabilitação" das pessoas que aí estavam: acompanhá-los e cuidá-los com o objetivo de que voltem a conviver integrados à comunidade, que possam contar com a rede de apoio que ela oferece, que refaçam ou façam novos laços sociais, que assumam o controle sobre suas vidas, que se insiram no mercado de trabalho, que vivam de forma autônoma. Os tratamentos e intervenções de equipes de saúde poderiam continuar por longo tempo dependendo do caso, mas o que importa é que seriam oferecidas outras formas e em outros espaços bem diferentes dos hospitais psiquiátricos. A pessoa em sofrimento mental, tratada como cidadã, deveria participar em todos os aspectos da vida social, com acesso aos seus bens materiais e culturais.

A I Conferência Nacional de Saúde Mental prezou pelo fim dos hospitais psiquiátricos e pela criação de uma rede de atenção substituta, com espaços alternativos de atendimento. Seria importante que os profissionais que trabalhassem nesses novos espaços não repetissem a lógica manicomial de serviço, pois isso diminuiria toda a potência de uma reforma psiquiátrica. Ou seja: um espaço onde o paciente pode entrar e sair é bom, mas isto não será muito se ele não for tratado com respeito, como cidadão, a partir de uma relação baseada na confiança.

O trabalho se configura, então, como uma categoria fundamental da reforma psiquiátrica. Tanto aquele das equipes de saúde mental quanto aquele dos pacientes. Como pensar em um bom serviço de saúde mental se os próprios trabalhadores da equipe sofrerem de jornadas exaustivas, 
péssimas condições de trabalho e mau pagamento? Se não ingressarem no serviço público por mérito - por concurso público, como prevê a nossa constituição? Se não receberem uma formação adequada e se, no cotidiano do serviço, não houver previsão de capacitações e supervisões? Se a relação entre a gestão municipal e a equipe não for pautada pelo diálogo? Se não houver equipes multidisciplinares valorizadas? Se a demanda de trabalho for muito superior à possível?

No caso das pessoas em sofrimento mental, o trabalho pode representar a sobrevivência material, um espaço de socialização e de criação de vínculos afetivos, o reconhecimento social, a construção de uma nova identidade. Tudo isto em nada se parece com o entendimento pineliano de que é necessário destruir a loucura por meio da distração possível com o trabalho. O que destacamos é a possibilidade de que a vida tome novos sentidos - isto se o trabalho escolhido dá sentido à vida. Nem todo trabalho o faz, muito pelo contrário, muitas vezes são as condições de trabalho que favorecem os mais diversos adoecimentos.

Na I Conferência Nacional de Saúde Mental apareceram as diretrizes de um grande movimento brasileiro de reforma psiquiátrica. Esta reforma se deu de maneira diferente em todo território nacional, articulada com as características sócio-históricas específicas. Mas podemos dizer que a expressão Atenção Psicossocial agrega um continuum de cuidado, desde a promoção em saúde mental, prevenção de transtornos e agravos até o tratamento. As pessoas são tratadas de forma integral e como cidadãos, independente do diagnóstico que possuam. A ética deve prevalecer sobre a técnica, devendo o paciente construir, junto com a equipe, o seu plano terapêutico individual. As instituições totais devem ser abolidas. Instituições só devem existir como lugar de cuidado e de mediação entre o paciente e sua comunidade. Todos os tratamentos de cunho moral e ideológico devem ser extintos, uma vez que apenas servem para a criação e aumento dos preconceitos. A atenção da equipe não deve se centrar no sintoma ou na pessoa que apresenta o sintoma. É necessário agir socialmente, sobre os determinantes do adoecimento. Os centros 
de atenção psicossocial teriam função estratégica na articulação da atenção psicossocial no território.

\section{CENTROS DE ATENÇÃO PSICOSSOCIAL}

Com base nesses pressupostos, foram surgindo os primeiros Centros de Atenção Psicossocial. O primeiro deles, de nome Professor Luiz da Rocha Cerqueira, foi criado em 1986; portanto, ainda antes da efetivação do SUS. Os CAPS e Núcleos de Atenção Psicossocial (NAPS) foram, timidamente, espalhando-se e iniciando atuações diversas e bem sucedidas ao longo do Brasil.

A partir de 1992, este modelo foi oficialmente adotado pelo Ministério da Saúde. Para o Ministério,

Os CAPS são instituições destinadas a acolher os pacientes com transtornos mentais, estimular sua integração social e familiar, apoiá-los em suas iniciativas de busca da autonomia, oferecer-Ihes atendimento médico e psicológico. Sua característica principal é buscar integrá-los a um ambiente social e cultural concreto, designado como seu 'território', o espaço da cidade onde se desenvolve a vida quotidiana de usuários e familiares. Os CAPS constituem a principal estratégia do processo de reforma psiquiátrica. (BRASIL, 2004, p. 9)

Dentro desta definição, é possível criar distintas formas de atuação. O principal é compreender a dimensão de estratégia: o CAPS não se confunde com o que acontece dentro das paredes de um espaço chamado CAPS. Ao contrário, ele é a estratégia criada a partir de uma lógica própria. Nesse sentido, não adianta ter um espaço físico diferente de um manicômio e funcionar segundo a lógica do manicômio.

O CAPS lida com o sofrimento humano que pode ou não tomar a forma de transtorno mental. Assim, não importaria o diagnóstico e nem a gravidade do sofrimento ou transtorno: o CAPS seria responsável pelo cuidado e pelo acompanhamento da pessoa em sofrimento. Foi criada a 
nomenclatura "Transtornos Mentais Severos e/ou Persistentes" quando se apresenta um quadro de grave comprometimento psíquico. Pessoas com esses transtornos são público prioritário dos CAPS não só por causa da gravidade de sua situação, mas também por uma questão histórica: eram o principal público dos manicômios. Uma vez que estes foram gradativamente extintos, foi necessário criar um lugar de atenção, já que vários pacientes internos por muitos anos apresentavam dificuldades diversas quanto à inserção comunitária. Muitos já nem tinham mais contato com suas famílias!

Portanto, a equipe do CAPS deve ter como fim último o exercício da cidadania destas pessoas, com a reintegração às atividades comunitárias. Isso significa poder estudar, trabalhar, frequentar os espaços de lazer da comunidade, viver de forma autônoma, da maneira que a própria pessoa julgar melhor. No início, isto é muito difícil, por isso exige o acompanhamento mais próximo e frequente da equipe de saúde. Mas as experiências bem-sucedidas de atenção possibilitam que as condições de cuidado se modifiquem. Por isso, Rabelo (2006, p. 28) substitui o conceito de alta pelo "de 'cuidado', até quando for necessário" e acrescentaríamos: da maneira que for necessária.

Isto porque o fato de duas pessoas terem a mesma doença não significa que elas devam ser tratadas da mesma maneira. 0 paciente, tomado como sujeito de sua própria história, deve participar da elaboração do que chamamos de plano terapêutico individual.

Somos acostumados a nos consultar com os médicos. Do alto de sua sabedoria - de quem estudou para isso - eles fazem receitas que devemos seguir. Muitas vezes, não concordamos com o tratamento, não gostamos dele ou do médico, ou por condições específicas, não temos como seguir as instruções daquela maneira. Por isso, frequentemente, o tratamento falha e o paciente é culpabilizado por isso, pois o seu dever seria seguir exatamente a ordem médica.

No campo da saúde mental compreendemos primeiramente que, independente da expertise ou da especialidade do profissional de saúde, 
o paciente deve ser atendido por alguém em quem ele confie. Por isso, o técnico de referência que o auxiliará a buscar soluções para os seus problemas será escolhido pelo vínculo com o paciente, e não por qualquer motivo administrativo.

Seguindo a mesma filosofia, é possível pensar o conceito de território. Uma vez que há um sistema público de saúde, faz-se necessário ordenar o seu funcionamento a partir de critérios específicos, como os territoriais e epidemiológicos. Entretanto, entendemos que o território de que falamos é um território vivo, o lugar em que o sujeito constituiu suas vivências comunitárias, estabeleceu seus laços afetivos, construiu as suas memórias, sua identidade e sua relação com o mundo. Por isso, trabalhar com um sujeito é atuar junto às instituições, organizações e pessoas que fazem parte do território vivido. Pensemos em Aquipiora: como tratar os pacientes com síndrome do pânico, sem lembrar que, a cada dia, mais crianças estão se afastando de suas famílias porque, no seu território, não há condições de estudo?

Nesse sentido, a definição de CAPS do Ministério da Saúde é reducionista e adaptacionista. Não basta integrar o sujeito a um ambiente, porque, muitas vezes, é este ambiente que favorece o adoecimento. Deve-se transformar o ambiente. Além disso, o CAPS não visa meramente oferecer atendimento médico e psicológico porque as profissões medicina e psicologia não dão conta da complexidade do fenômeno mental. Neste sentido, concordamos com Sampaio e Barroso (1994, p. 2), quando definem CAPS da seguinte maneira:

Um Centro de Atenção Psicossocial-CAPS constitui serviço extra-hospitalar de assistência pública, estatal ou contratado, aos problemas de saúde mental, individual e coletiva. Caracteriza-se por multiplicidade crítica de funções e técnicas, prática interdisciplinar e acessibilidade local. Por sua complexidade deve situar- se em distritos sanitários de regiões metropolitanas, ou em municípios de porte médio ou grande, coordenando a política de saúde mental de onde se instale e servindo de referência a equipes 
mínimas de saúde mental em municípios de pequeno porte na região de cobertura.

Observe-se que, enquanto a definição do ministério foca no sujeito, a de Sampaio e Barroso (1994) distribui a assistência tanto no que tange aos problemas individuais quando aos coletivos. A multiplicidade crítica de funções e técnicas não permite que elas sejam limitadas a profissões específicas, uma vez que a atuação em um CAPS precisa se inventar a partir de cada situação cotidiana. Desta maneira, para além do sistema de saúde, um CAPS deve atuar conjuntamente com os equipamentos das políticas públicas de assistência social, educação, trabalho e geração de renda, cultura, entre outros. Para os autores citados, um dos objetivos do CAPS é "apoiar a promoção de cidadania e a construção coletiva da qualidade de vida”. (SAMPAIO; BARROSO, 1994, p. 2)

Isto porque o exercício de cidadania, em si, é terapêutico. O que as autoras deste livro defendem é que o cerceamento dos direitos próprios à cidadania, somado a configurações afetivas e materiais, ligam-se às várias formas de adoecimento mental. Por isso, a construção da qualidade de vida deve ser tomada de forma coletiva. Isto se torna fundamental dada a herança histórica relacionada ao louco, que até hoje convive com situações de preconceito e segregação.

O que está aqui sendo dito não pode ficar a cargo da boa intenção dos profissionais. Por isso, é necessário que os trabalhadores da saúde mental, em especial os do CAPS, tenham um cotidiano de trabalho com condições dignas; com previsão para capacitações internas; realização de pesquisas; e supervisões sistemáticas, em que também os profissionais possam ser cuidados. A hierarquia, seja entre equipe e paciente, seja dentro da própria equipe, deve ser diminuída ao máximo, já que muitas vezes ela cristaliza e dificulta as relações.

Na prática, além das atividades acima citadas, o CAPS realiza:

Acolhimento: tem este nome porque não se trata de receber, administrativamente, um paciente. O profissional de nível superior que o 
realiza deve ter uma escuta atenta e manejo adequado do conteúdo que ali é dito, além de boa capacitação em psicopatologia. No acolhimento, inicia-se o vínculo com o profissional e com o CAPS.

Plano terapêutico individual: é realizado de acordo com os problemas e dificuldades encontrados. Elege-se o técnico de referência do paciente ou do caso a partir do vínculo estabelecido.

Atendimentos individuais e em grupo: são diversos, realizados com distintos profissionais e objetivos. Podem se configurar como escuta de apoio, orientação, mediação, ou tratamento propriamente dito. Os atendimentos individuais podem também servir à avaliação para outros órgãos, como aqueles ligados à justiça.

Ambulatório: o tratamento ambulatorial deve se utilizar de técnicas terapêuticas diversificadas e evitar o uso exclusivo de intervenção farmacológica.

Retaguarda às internações psiquiátricas: frequentemente, é possível evitar a internação psiquiátrica. Quando ela acontece, o desejável é que o paciente seja atendido por equipe capacitada nos hospitais gerais. Entretanto, os CAPS ainda convivem com instituições manicomiais. De qualquer maneira, a equipe do CAPS deve continuar o acompanhamento do paciente em crise, não importa em qual instituição ele esteja, pois ela permanece exercendo a função de cuidadora responsável.

Oficinas: Almeida et al. (2004) dividem as modalidades de oficinas a partir de seus objetivos: as terapêuticas, as autoexpressivas e as de habilitação social. No caso das terapêuticas, objetiva-se dar uma resposta clínica a uma dificuldade clínica. Já as autoexpressivas servem a quem as desejem: configuram-se como "um espaço livre para um conjunto de experiências simbólicas e criativas do ser humano, sua capacidade de fantasiar e de brincar, sem urgência, sem necessidade imediata, sem objetivo específico". (ALMEIDA et al, p. 119) As de habilitação social se destinam àqueles pacientes fora do estado agudo e de crise e podem se realizar em qualquer espaço da cidade. A partir do plano terapêutico individual, o paciente pode se inserir em atividades sociais, que, a partir 
daí, tomam o caráter de habilitação. É uma maneira não só de integração do paciente, mas de expor à sociedade ao convívio com as diferenças. É importante salientar que qualquer oficina ou mesmo qualquer relação podem ser terapêuticas, caso haja uma disposição do terapeuta para escutar e se oferecer como alguém que provê auxílio, mostra-se confiável e encoraja a autonomia. Ao mesmo tempo, mesmo um psicoterapeuta graduado pode não exercer uma função terapêutica, caso não apresente estas características.

Matriciamento: o apoio matricial é uma modalidade de atuação formulada por Gastão Wagner Campos, em 1999. "O matriciamento deve proporcionar a retaguarda especializada da assistência, assim como um suporte técnico-pedagógico, um vínculo interpessoal e o apoio institucional no processo de construção de projetos terapêuticos junto à população". (CHIAVERINI, 2011, p. 14-15) Tal suporte técnico-pedagógico já se fazia presente no cotidiano dos CAPS mesmo antes da formulação deste conceito, na forma das atividades de assessoria, formação, supervisão de serviços diversos, comunicação e crítica social, como defendido por Sampaio e Barroso (1994).

Assembleias: o modelo de assembleia segue a previsão do SUS para participação popular. Enquanto que conselhos e conferências de saúde são modelos de participação popular na cidade, a assembleia seria um momento, no cotidiano do serviço, em que todos os interessados poderiam discutir sobre a atuação do CAPS, avaliá-lo e contribuir para melhorá-lo. Por isso a necessidade de que ocorram com uma periodicidade predefinida. Esta é também uma estratégia para diminuição da hierarquia entre trabalhadores, usuários e familiares.

Visitas à comunidade: grande parte das vezes, a atenção em saúde mental não se dá no espaço do CAPS. Ela pode se dar em qualquer espaço da comunidade, em forma de reuniões, rodas de conversa, capacitações. Podem também tomar a forma de visitas domiciliares para pacientes específicos, para acompanhamento deles ou de suas famílias, substituindo a lógica da institucionalização pela do cuidado. Há também 
a realização da busca ativa: por vezes, alguém ou uma situação, aos olhos da equipe, merece uma intervenção em saúde mental. Mesmo que o CAPS ainda não tenha sido solicitado, é possível se aproximar de forma não impositiva, e colocar-se à disposição para ajudar.

O que é preciso salientar é que toda atividade proposta pelo CAPS deve tomar como pressuposto a cidadania do usuário. Portanto, deve-se evitar atividades que, ao invés de proporcionar o convívio comunitário, segreguem ainda mais os pacientes. Fazer, rotineiramente, atividades como "festa dos usuários do CAPS" ou ainda criar espaços como brinquedotecas dentro dos CAPS podem servir à segregação social: o usuário adulto deve ser incentivado a participar das atividades de lazer de sua comunidade, assim como as crianças devem conviver nas brinquedotecas municipais, independente de diagnósticos. Assim se dá o processo terapêutico a partir da vivência da cidadania e se previne preconceitos.

Ao final deste capítulo, a nossa mensagem é que, embora já haja mais de 20 anos de experiências em atenção psicossocial, com diversos equipamentos CAPS espalhados pelo Brasil, o que temos são diretrizes e valores de atuação. As práticas se mostram muito diversas e assim devem ser, dadas as diferenças sociais encontradas em cada lugar. Entretanto, é preciso avaliá-las: em que medida, realmente, cumprem o que prometem? Caso não cumpram, o que deve ser modificado? Essas avaliações nunca podem cessar, uma vez que os transtornos mentais mudam de acordo com as determinações históricas e, portanto, as práticas deste campo permanecerão em contínua metamorfose.

Você já conhecia os CRAS? Procure mais informações sobre as políticas federais de assistência social e descubra como é possível construir uma ação intersetorial, especialmente com a saúde.

Que problemas você vê na forma de organização do CRAS e do CAPS de Aquipiora? Como eles poderiam ser solucionados? 
A partir do que você aprendeu sobre as atividades que um CAPS pode realizar, elabore um plano de atuação relacionado aos casos de síndrome do pânico em Aquipiora. 


\section{CONCLUSÕES}

O Sistema Único de Saúde foi uma conquista junto a várias outras que fizeram parte do processo de redemocratização brasileira. O SUS era a forma de concretizar o artigo 196 da então recém-publicada Constituição Federal, que afirmava a saúde como direito de todos e dever do Estado.

Para garantir este direito, seria necessário que o SUS fosse universal, resolutivo, descentralizado, equitativo, intersetorial, racional e prestasse assistência de saúde integral ao usuário, entendido como pessoa autônoma e que deve ser respeitada em sua integridade física e moral. o SUS tanto foi construído a partir de embates históricos num contexto de luta pela democracia como, uma vez criado, busca manter esse espírito, garantindo a participação popular na construção e acompanhamento das políticas públicas de saúde. Essa participação ocorreria, sobretudo, por meio dos conselhos e conferências de saúde, em nível municipal, estadual e federal.

Portanto, múltiplos saberes deveriam se somar no debate sobre o processo saúde-doença. A ética deveria prevalecer sobre a técnica: nenhum tratamento que desrespeitasse a autonomia do paciente poderia ser admitido. Pelo contrário, este seria corresponsável não só pelos cuidados que receberia, mas também seria respeitado em sua capacidade de construir as políticas públicas de saúde. É, fundamentalmente, uma 
redistribuição de forças na sociedade, em que o cidadão é conclamado a atuar junto ao Estado. No caso da saúde mental, essa experiência é ainda mais radical, já que usualmente estes pacientes viveram situações de segregação extrema.

Modificou-se o modelo de atenção e outros campos de atuação em saúde, que anteriormente não tinham o lugar merecido, foram convocados para tornar o sistema racional: as vigilâncias sanitária e epidemiológica. Buscou-se organizar o sistema, trabalhando-se a partir de distritos sanitários, da adscrição da população em unidades básicas de saúde e elegendo-se a família como núcleo central de abordagem. A atenção passou a ser dada nos níveis de promoção, prevenção, tratamento e reabilitação em saúde. O que tornou as ações muito mais amplas, adotando-se a perspectiva da necessária criação de ambientes saudáveis. Esta criação não seria possível meramente por normativas ou diretrizes ministeriais. Seria necessária a educação em saúde e, também, a participação comunitária nesta criação.

Os debates que fundamentaram o campo da saúde coletiva tiveram os seus correlatos no desenvolvimento de disciplinas específicas. Assim, a odontologia, em sua formatação tradicional, seguia o modelo flexneriano: mecanicista, biologicista, individualista, especialista, tecnicista, curativista, mercantilista. A discussão sobre prevenção em saúde, já presente em outras áreas da saúde na década de 1960, possibilitou a odontologia preventiva. A tentativa de possibilitar um maior acesso à odontologia, por meio do desenvolvimento de equipamentos, materiais e rotinas, além da redução de custos, gerou o movimento da odontologia simplificada. Posteriormente, esta disciplina superou o reducionismo de um preventivismo desconectado do necessário tratamento e ainda de uma simplificação da odontologia, com meros fins de redução de custos e evoluiu para uma compreensão integral de odontologia. Finalmente, a compreensão de que existe o campo da saúde bucal coletiva, situa-a em um contexto maior de compreensão sobre o processo saúde-doença, atenta a seus determinantes sociais. 
No que se refere à saúde mental, há uma maior complexidade porque este campo agrega fenômenos que nem sempre foram vistos como doença, e que frequentemente estiveram próximos de experiências de segregação, marginalização, estigmatização e maus tratos.

O financiamento de hospitais psiquiátricos por parte do poder público, no Brasil, foi ainda mais perverso, porque o paciente rentável era aquele que permanecia indefinidamente internado. Portanto, modificar o modelo de atenção seria, literalmente, libertar uma clientela cronificada por décadas nos hospitais psiquiátricos, o que significaria um forte trabalho de inserção destas pessoas na vida comunitária.

Nacionalmente, o SUS permitiu a criação de serviços substitutivos aos hospitais psiquiátricos. O equipamento substitutivo por excelência adotado foi o centro de atenção psicossocial. Por mais que os CAPS tenham ações diversas ao longo das regiões ou mesmo em uma cidade só, sua existência serve para situar algumas formas de sofrimento humano no âmbito da saúde. Busca-se se afastar de perspectivas moralizantes e se compreender os fenômenos humanos em uma perspectiva de saúde que engloba, também, determinantes sociais e psíquicos. Ou seja: as políticas atuais de saúde mental, assim como de saúde bucal e de todo o SUS se voltam para o cidadão, independente de quem seja e do que lhe afeta. Cabe ao gestor e ao trabalhador uma postura crítica diante dos problemas que surgem, na formulação de estratégias que se apresentem de maneira integral e propiciando a continuidade dos cuidados prestados.

Buscamos apresentar um esboço de como e porquê se deu a criação do SUS, e das formas que tomou em seus quase 30 anos iniciais. O que virá será construção da prática cidadã cotidiana nos jogos de múltiplas forças a que toda construção social está submetida. Jogo que se reinventa diante de cada contexto, momento e personagens envolvidos. 


\section{REFERÊNCIAS}

ALMEIDA, A. G. M. et. al. Oficinas em saúde mental: relato de experiências em Quixadá e Sobral. In: COSTA, C. M.; FIGUEIREDO, A. C. (Orgs.). Oficinas terapêuticas em saúde mental: sujeito, produção e cidadania. Rio de Janeiro: Contra capa, 2004.

BARATA, R. C. B.. A historicidade do conceito de causa. In: CARVALHEIRO, J. R. (org.) Textos de Apoio: epidemiologia 1. 2. ed. Rio de Janeiro: ENSP: ABRASCO, 1990.

BARROS, E. O controle social e o processo de descentralização dos serviços de saúde. In.: MINISTÉRIO DA SAÚDE. Incentivo à participação popular e controle social no SUS: textos técnicos para conselheiros de saúde. Brasília, DF: Ministério da Saúde, Coordenação de Informação, Educação e Comunicação, 1994. 29-37.

BERLINGUER, G. A doença. São Paulo: Hucitec: CEBES, 1988. 150 p.

BLEICHER, L. Promoção da saúde. In: SECRETARIA DA SAÚDE; et al. (Re) Construindo ações coletivas em saúde bucal. Fortaleza, 2001.

BOTAZZO, C. Saúde bucal coletiva: um conceito em permanente construção. São Paulo, 1991. 12 p. Mimeografado.

BRASIL. Constituição (1988). Constituição da República Federativa do Brasil. Brasília, DF: Senado, 1988. Disponível em: <http://www.planalto.gov.br/ccivil_03/ constituicao/constituicao.htm>. Acesso em: 16 fev. 2013. 
BRASIL. Ministério da Saúde. Portaria n. 2.488, de 21 de outubro de 2011. Aprova a Política Nacional de Atenção Básica, estabelecendo a revisão de diretrizes e normas para a organização da Atenção Básica, para a Estratégia Saúde da Família (ESF) e o Programa de Agentes Comunitários de Saúde (PACS). Diário Oficial da União, Brasília, DF, 21 out. 2011. Disponível em: <http://bvsms.saude.gov.br/bvs/ saudelegis/gm/2011/prt2488_21_10_2011.html>. Acesso em: 15 fev. 2013.

BRASIL. Lei no 8.080, de 19 de setembro de 1990. Dispõe sobre as condições para a promoção, proteção e recuperação da saúde, a organização e o funcionamento dos serviços correspondentes e dá outras providências. Diário Oficial da República Federativa do Brasil, Brasília, DF, 20 set. 1990a. Disponível em: <http://www. presidencia.gov.br/ccivil_03/Leis/L8080.htm>. Acesso em: 16 fev. 2013.

BRASIL. Lei n 8.142, de 28 de dezembro de 1990. Dispõe sobre a participação da comunidade na gestão do Sistema Único de Saúde (SUS) e sobre as transferências intergovernamentais de recursos financeiros na área da saúde e dá outras providências. Diário Oficial da República Federativa do Brasil, Brasília, DF, 31 dez. 1990b. Disponível em: <http://www.presidencia.gov.br/ccivil_03/Leis/L8142. htm>. Acesso em: 16 fev. 2013.

BRASIL. Conselho Nacional de Saúde. Resolução n 33, de 1992. Homologo a Resolução n 33, nos termos do Decreto de 12 de novembro de 1991. Diário Oficial da União, Brasília, DF, 15 jan. 1993. Disponível em: <http://conselho.saude.gov.br/ resolucoes/reso_92.htm> Acesso em: 16 fev. 2013.

BRASIL. Ministério da Saúde. Portaria n. 2.203, de 5 de novembro de 1996. Aprova a Norma Operacional Básica do Sistema Único de Saúde - NOB 1/96. Diário Oficial da União, Brasília, DF, 6 nov. 1996. Disponível em: <http://conselho.saude.gov.br/ legislacao/nobsus96.htm>. Acesso em: 16 fev. 2013.

BRASIL. Ministério da Saúde. Portaria n. 95, de 26 de janeiro de 2001. Aprova a Norma Operacional da Assistência à Saúde - NOAS-SUS 01/2001. Diário Oficial da União, Brasília, DF, 26 jan. 2001a. Disponível em: <http://bvsms.saude.gov.br/bvs/ saudelegis/gm/2001/prt0095_26_01_2001.html>. Acesso em: 16 fev. 2013.

BRASIL. Ministério da Saúde. Portaria n. 267/GM, de 6 de março de 2001. Aprova as normas e diretrizes de inclusão da saúde bucal na estratégia do Programa de Saúde da Família (PSF). Diário Oficial da União, Brasília, DF, 7 mar. 2001b. Disponível em: <http://dtr2004.saude.gov.br/susdeaz/legislacao/arquivo/32_Portaria_267_ de_06_03_2001.pdf>. Acesso em: 20 fev. 2003. 
BRASIL. Ministério da Saúde. Portaria n. 1.444, de 28 de dezembro de 2000. Estabelece incentivo financeiro para a reorganização da atenção à saúde bucal prestada nos municípios por meio do Programa de Saúde da Família. Diário Oficial da União, Brasília, DF, 1 jan. 2001c. Disponível em: <http://www.brasilsus.com.br/ legislacoes/gm/16285-1444.html>. Acesso em: 20 fev. 2003.

BRASIL. Ministério da Saúde. Portaria n. 373, de 27 de fev.ereiro de 2002. Aprova a Norma Operacional da Assistência à Saúde - NOAS-SUS 01/2002. Diário Oficial da União, Brasília, DF, 27 fev. 2002. Disponível em: <http://bvsms.saude.gov.br/bvs/ saudelegis/gm/2002/prt0373_27_02_2002.html>. Acesso em: 16 fev. 2013.

BRASIL. Ministério da Saúde. Portaria n. 1886/GM, de 18 de dezembro de 1997. Aprova as Normas e Diretrizes do Programa de Agentes Comunitários de Saúde e do Programa de Saúde da Família. Diário Oficial da União, Brasília, DF, 22 dez. 1997.

BRASIL. Ministério da Saúde. Portaria n. 1.348/GM, de 18 de novembro de 1999. Define critérios para a regulamentação do incentivo a municípios que tenham projetos similares ao Programa de Saúde da Família. Diário Oficial da União, Brasília, DF, 19 nov. 1999. Disponível em: < http://sna.saude.gov.br/legisla/legisla/ prog_pacs_psf/>. Acesso em: 16 fev. 2013.

BRASIL. Ministério da Saúde. Portaria n. 157/GM, de 19 de fev.ereiro de 1998. Estabelece os critérios de distribuição e requisitos para a qualificação dos Municípios aos incentivos ao Programa de Agentes Comunitários de Saúde e ao Programa de Saúde da Família. Diário Oficial da União, Brasília, DF, 26 mar. 1998. Disponível em: <http://sna.saude.gov.br/legisla/legisla/prog_pacs_psf/>. Acesso em: 16 fev. 2003.

CARVALHO, A. I. de. Conselhos de saúde no Brasil: participação cidadã e controle social. Rio de Janeiro: FASE/IBAM, 1995. 135 p.

CARVALHO, G. I. de; SANTOS, L. Comentários à Lei Orgânica da Saúde (Lei 8.080/90 e Lei 8.142/90): Sistema Único de Saúde. 2. ed. atual. e ampl. São Paulo: Hucitec, 1995. 394 p.

CECCARELLI, P. O sofrimento psíquico na perspectiva da psicopatologia fundamental. Psicologia em Estudo, Maringá, v. 10, n. 3, p. 471-477, set./dez. 2005.

CHAVES, M. M. Odontologia social. 3. ed. São Paulo: Artes Médicas, 1986. 448 p.

CHIAVERINI, D. H. (Org.) et al. Guia prático de matriciamento em Saúde Mental. Brasília, DF: Ministério da Saúde: Centro de Estudos e Pesquisas em Saúde Coletiva, 2011. 236 p. 
COMISSÃO MUNDIAL SOBRE MEIO AMBIENTE E DESENVOLVIMENTO. NosSO Futuro Comum. 2. ed. Rio de Janeiro: Ed. FGV, 1991. 430 p.

CORDÓN, J. A.; GARRAFA, V. Prevenção versus preventivismo. Divulgação em saúde para debate, Londrina, v. 6, p. 10-16, out. 1991.

CORDÓN, J. A. Sobre a construção histórica do conceito de odontologia em saúde coletiva. Ação Coletiva, Brasília, DF, v. 1, n. 1, p. 7-26, 1998.

COSTA, N. R. Estado, educação e saúde: a higiene da vida cotidiana. In: CENTRO DE ESTUDOS EDUCAÇÃO E SOCIEDADE. Educação e saúde. São Paulo: Cortez, 1984. p. 5-27. (Cadernos do CEDES, 4).

DELIBERAR. In: DICIONÁRIO de Português online. Michaelis, 2012. Disponível em: <http://michaelis.uol.com.br/moderno/portugues/index.php?lingua=portuguesportugues\&palavra=deliberar $>$. Acesso em: 19 fev. 2013.

DODGE, R. A Equidade, a Universalidade e a Cidadania em Saúde, Vistas sob o Prisma da Justiça. Revista Bioética, Brasília, DF, v.5, n.1, nov. 1997. Disponível em: <http://revistabioetica.cfm.org.br/index.php/revista_bioetica/article/ view/369/469>. Acesso em: 13 fev. 2013.

ESPÍRITO SANTO, C. C. et al. Memórias e representações sociais do Sistema Único de Saúde por seus usuários. Esc. Anna Nery, Rio de Janeiro, v. 16, n. 1, p. 96-102, mar. 2012.

FERNANDES, M. Aula de geografia e algumas crônicas. Campina Grande, PB: Bagagem, 2003. $109 \mathrm{p}$.

FISCHMANN, A. Vigilância epidemiológica. In: ROUQUAYROL, Z. Epidemiologia e saúde. 4. ed. Rio de Janeiro: Medsi. 1993. p. 421-441.

FOUCAULT, M. Doença mental e psicologia. Rio de Janeiro: Tempo Brasileiro, 1975. $99 \mathrm{p.}$

FREIRE, P. Pedagogia do oprimido. 24. ed. Rio de Janeiro: Paz e Terra, 1997. 245 p.

FURTADO, C. O mito do desenvolvimento econômico. Rio de Janeiro: Paz e Terra, 1996. 89 p.

GARRAFA, V. Bioética e odontologia In: KRIGER, L. (Coord.); ASSOCIAÇÃO

BRASILEIRA DE ODONTOLOGIA DE PROMOÇÃO DE SAÚDE: Promoção de saúde bucal. São Paulo: ABOPREV: Artes Médicas, 1997. p. 465-475. 
HINO, P. et al. Geoprocessamento aplicado à área da saúde. Revista LatinoAmericana de Enfermagem, Ribeirão Preto, SP, v. 14, n. 6, p. 939-943, dez. 2006.

HERCULANO, S. C. Do desenvolvimento (in)suportável à sociedade feliz. In: GOLDEMBERG, M.; VIOLA, E. (Coord.). Ecologia, ciência e política. Rio de Janeiro: Revan, 1992. p. 9-47.

IBGE. Pesquisa Nacional de Amostra de Domicílios. Rio de Janeiro, v. 29, 2008.

JORGE, E. A. Financiamento setorial do SUS e a questão da municipalização da saúde. In: NÚCLEO DE ESTUDOS EM SAÚDE PÚBLICA. Incentivo à participação popular e controle social no SUS. Brasília, DF: Ministério da Saúde, Coordenação de Informação, Educação e Comunicação, 1994. p. 45-54.

LIRA NETO. O poder e a peste: a vida de Rodolfo Teófilo. Fortaleza: Ed. Fundação Demócrito Rocha, 1999. 223 p.

LOUREIRO, C. A.; OLIVEIRA, F. J. F. A condição de saúde bucal e dos serviços públicos em Minas Gerais e uma proposta de mudança do modelo de intervenção. Belo Horizonte: Estação Saúde, 1993.

MEHRY, E. Organizações sociais: para que? [S.I.], ago. 1998. Disponível em <http://www.uff.br/saudecoletiva/professores/merhy/artigos-15.pdf>. Acesso em: 13 fev. 2013.

MENDES, E. V. (Org.). Distrito sanitário: o processo social de mudança das práticas sanitárias do Sistema Único de Saúde. São Paulo: Hucitec: ABRASCO, 1995.

MENDES, E. V. A reforma sanitária e a educação odontológica. Cadernos de Saúde Pública, Rio de Janeiro, v. 2, p. 533-552, out. dez. 1986.

MENDES, E. V. Os grandes dilemas do SUS: tomo I. Salvador: Casa da Qualidade, 2001. $135 \mathrm{p}$.

MENDES, E. V. A atenção primária à saúde no SUS. Fortaleza, CE: Escola de Saúde Pública do Ceará, 2002. 89 p.

MINISTÉRIO DA SAÚDE; SECRETARIA DE ATENÇÃO À SAÚDE; DEPARTAMENTO DE AÇÕES PROGRAMÁTICAS ESTRATÉGICAS. Saúde mental no SUS: os centros de atenção psicossocial. Brasília, DF: Ministério da Saúde, 2004. 85 p.

MOYSÉS, S. T.; WATT, R. Promoção de saúde bucal: definições. In: BUISCHI, Y. de P. Promoção de saúde bucal na clínica odontológica. São Paulo: Artes Médicas, 2000. p. 1-22. 
NADANOVSKY, P. Promoção da saúde e a prevenção das doenças bucais. In: PINTO, V. G. Saúde Bucal Coletiva. 4. ed. São Paulo: Santos, 2000. p. 293-310.

NARVAI, P. C. Odontologia e saúde bucal coletiva. São Paulo: Hucitec, 1994. 113 p.

NARVAI, P. C. Saúde Bucal: assistência ou atenção? Oficina do Grupo de Trabalho "Odontologia em Silos - Sistemas Locais de Saúde". São Paulo: Rede CEDROS, 1992.

PAIM, J. S., ALMEIDA FILHO, N. Saúde coletiva: uma "nova saúde pública" ou campo aberto a novos paradigmas? Revista de Saúde Pública, São Paulo, v. 32, n. 4 , p. 299-316, ago. 1998.

PROMOÇÃO da saúde: Carta de Ottawa, Declaração de Adelaide, Declaração de Sundsvall, Declaração de Bogotá. Brasília, DF: Ministério da saúde, 1996. 48 p.

PROMOVER. In: DICIONÁRIO de Português online. Michaelis, 2012. Disponível em: <http://michaelis.uol.com.br/moderno/portugues/index.php?lingua=portuguesportugues\&palavra=promover $>$. Acesso em: 20 fev. 2013.

PUGIN, S. R.; NASCIMENTO, V. B. Principais marcos das mudanças institucionais no setor saúde (1974-1996). São Paulo: CEDEC , 1996. 36 p.

QUEIROZ, I. S. Os programas de redução de danos como espaços de exercício da cidadania dos usuários de drogas. Psicologia Ciência e Profissão, Brasília, DF, v. 21, n. 4, p. 2-15, dez. 2001.

RING, M. E. História ilustrada da odontologia. São Paulo: Manole, 1998. 319 p.

ROUQUAYROL, Z. Epidemiologia e saúde. 4. ed. Rio de Janeiro: MEDSI, 1993.

RABELO, A. R. Um manual para o CAPS: Centro de Atenção Psicossocial. 2. ed. rev. e ampl. Salvador: EDUFBA, 2006. 247 p.

SAIBA mais sobre o protocolo de Kyioto. Folha Online: São Paulo, 27 ago. 2002.

Disponível em: <http://www1.folha.uol.com.br/folha/ciencia/ult306u6836.shtml>. Acesso em: 15 fev. 2013.

SAMPAIO, J. J. C. Epidemiologia da imprecisão: processo saúde/doença mental como objeto da epidemiologia. Rio de Janeiro: Ed. FIOCRUZ, 1998. 133 p.

SAMPAIO, J. J. C.; BARROSO, C. M. C. Manual de organização do Centro de Atenção Psicossocial de Quixadá. Quixadá, 1994. Disponível em:

<http://www.ccs.saude.gov.br/memoria\%20da\%20loucura/itinerancia/fortaleza/ Carcaps.pdf>. Acesso em: 13 fev. 2013. 
SANTOS, M. et al. Território e sociedade: entrevista com Milton Santos. São Paulo: Ed. Fundação Perseu Abramo, 2000. 127 p.

SHEIHAM, A., MOYSÉS, S. J. O papel dos profissionais de saúde bucal na promoção de saúde. In: BUISCHI, Y. P. Promoção de saúde bucal na clínica odontológica. São Paulo: Artes Médicas, 2000. p. 23-37.

SNOW, J. Sobre a maneira de transmissão do cólera. 2. ed. São Paulo: HUCITEC, 1999. $249 \mathrm{p}$.

SOUZA, E. C. F.; OLIVEIRA, A. G. R. C. O processo saúde-doença: do xamã ao cosmos.

Disponível em: <https://www.yumpu.com/pt/document/view/16975531/oprocesso-saude-doenca-do-xama-ao-cosmos-artigo-cientifico >. Acesso em: 13 fev. 2013

ZANETTI, C. H. G. As marcas de mal-estar social no sistema nacional de saúde tardio: o caso das políticas de saúde bucal no Brasil dos anos 80. 1993. 142 f. Dissertação (Mestrado em Saúde Pública) - Escola Nacional de Saúde Pública, Fundação Oswaldo Cruz, Rio de Janeiro, 1993.

ZANETTI, C. H. G. Em busca de um paradigma de programação local em saúde bucal mais resolutivo no SUS. Divulgação em saúde para debate, Londrina, n. 13, p. 18-35, jul. 1996. 


\begin{tabular}{|c|c|}
\hline & COLOFÃO \\
\hline Formato & $19 \times 22 \mathrm{~cm}$ \\
\hline Tipologia & TT Rounds \\
\hline Papel & $\begin{array}{l}\text { Alcalino } 75 \mathrm{~g} / \mathrm{m}^{2} \text { (miolo) } \\
\text { Cartão Supremo } 300 \mathrm{~g} / \mathrm{m}^{2} \text { (capa) }\end{array}$ \\
\hline Impressão & $\begin{array}{l}\text { EDUFBA (miolo) } \\
\text { Cartograf (capa e acabamento) }\end{array}$ \\
\hline Tiragem & 500 exemplares \\
\hline
\end{tabular}

